A STUDY OF THE AESORPTION AND

LOSS OF SOIL MOISTURE

by

Russell Manning Vifquain, A.B.

SUBIITTED IN PARTIAL FULFILMENT OF THE

REQUIREMENTS FOR THE DEGREE OF

MASTER OF ARTS

in the

GRADUATE SCHOOL

of the

UNIVERSITY OF MISSOURI

1917 
Introduction

Previous investigations -

Investigations concerned with percolation and evap-

oration losses.................. 4

Investigations concerned with the action of capillarity 16

Investigations concerned with run-off .......... 24

Plan and acope of investigaticn. . . . . . . . . . . 27

Laboratory experiments -

Experiment I. - Depth of water-table as effecting capil-

lary rise of moisture in the soil and evaporation

losses................. 28

Experiment A -

Plan of experiment . . . . . . . . . . . .

Plate I, Diagram of soil cylinder and measuring device............. 30

Experimental methoda . . . . . . . . . . . 33

Experimental data -

Table 1. - Inches of water taken up by soil columns ..............

Table 2. - Ounces of water lost from soil columns ............. . . 34

Table 3. - Ounces of water lost compared with ounces of water absorbed ........

Table 4. - Loss of water fer acre per series for 39 days. . . . . . . . . . .

Plate II, Evaporation loss compared to watertabie loss............. 35

General observations ........... 36

Experiment B -

Experimental methods . . . . . . . . . 38

Experimental data -

Table 5. - Ounces water absorbed by soil columns . . . . . . . . . . . .

Table 6. - Ounces water lost by soil columns.

Table 7. - Ounces water lost in quarter perioda . . . . . . . . . . .

Table 8. - Water lost compared with water absorbed ............... 43

Plate III, Evaporation 1083 compared with water-table loss........... 44

Table 9. - Evaporation from free water surface 45

Plate IV, Comparison of evaporation and watertable losses............. 46

General observations. . ........... 47

Discussions of results. . ........... 50

Experiment II. - Loss of water thru capiliarity with and againat gravity............... 53 Plan of Experiment .............. 54

Experimental methods. . ............ 55

Experimental data -

Table 10. - Evaporation 108s, with and against gravity ............. 58

Plate $v$, Curves showing rate and amount of evaporation losses with and against cravit 59 $1+5(j+250)$ 
General observations and discusion of results. . . 60

Field Experiments -

Experiment III. - A study of the aboorption, run-off, and

loss of moisture unier field conditions.......67

Plan of experiment. . . . . . . . . . ... 67

Plate VI, Diagram of field plots. . . . ... 69

Plate VII, Diragram of lysimeters. . . . ... 72

Table 12. - Water-holding capacity and wilting point of field soil.......... 75

Exoerimental methods ...............76

Experimental data. . . . . . . . . . 78

Table 13. - Effecto of rainfall upon scraped plot 78

Table 14. - Effecta of rainfall upon cultivated plot................. 79

Plate VIII, Relationship of rainfall to run-off, penetration, and erozion on cultivated and uncultivated soil. .......... 80

Table 15. - Percentage of Koisture in soil samples taken from plot $\mathrm{A}-\mathrm{Z} . . . . . . .81$

Table 16. - Percentage of Moizture in soil sampies taken from plot B-Z......... 82

Table 17. - Average percentage of moisture in soil samples. ............. 83

Table 18. - Evaporation effects upon rlots. . . 85

Plate IX, Storage of Moisture in Plots. . . .. 84

Table 19. - Moisture conditins in soil after six weeks of drying weather. . . . . . . 85

Table 20. - Noisture conditions in lyoimeters 85

Table 21. - Evaporation effecta upon lysimeters. 85

Table 22. - Weather observations....... 87

General observations.: . . . . . : . : . : : : 88

Bibliography . . . . : . : : : : : : : : : 99

\section{Photographs -}

No. 1. - Soil cylinders used in Exceriment I on platform

in greenholise................ . . 103

No. 2. - Soil cylinders used in Exueriment II. . . . . . 103

No. 3. - Fieza plots, showing surface conditions.... 104

No. 4. - Looking east acroas field plota. Teather

apparatus in fore ground. . . . . . . . . . . . 104

No. 5. - Lower end of field plots, showing catching arvaratus for run-off and lyoimetera. . . . . . . . 105

kc. 6. - Position of lysimeters when bottoms were installed. . . . . . . . . . . . . . . . . 106

No. 7. - Lysimeters on foundation before replacing soil.: 106 


\section{INTRODUCIION.}

The importance of soil moisture is realized by the common observer as his attention is attracted to the sufferIng vegetation in time of drought. Its greater importance is $r$ ealized by the few, who have investigated the problem and have discovered how intimately the supply of soll moisture is connected with plant life. The attempts to determine the relations existing between soil and plant have shown that the irfluercing factors are many and that the problem of controlling the soil moisture supply is a very complicated one.

It is generally accepted that the soil may retain it's moisture in three different atates, namely: hygroscoric, capiliary, and free or gravitational. These forms differ, not in their composition, but in the position which they occupy in relation to the soil particles. The hygroscopic and capillary water exist as film forms. They surround the soil particle, and are held partiy by the attraction of the particle, and partiy by the molecular attraction of the liquid. The hygroscopic film of water is spoken of as the water of condensation or adsorption; the capillary water as that portion of the film in which molecular movement, except for the influence of viscosity, is perfectly free and unimpeded. The free or gravitational water is termed that fortion of soil moisture which moves thru the soll unimpeded and percolates away. It is the moisture which is in the capillary state that concerno us most, inasnuch as it isiscapillary water that the plant is ablo to secure most of its supply. 
When rain or irrigation water enters the soil it is absorbed principally as capillary moisture. If more water falls than can at once penetrate, it runs off the surface and is known as 'runoff'. If an over supply enters the soil, it percolates away as free or gravitational water. What becomes of the amount retained by the soil, as capillary or fim water, is the important matter from the standpoint of the plant. That the plant uses large quantities of this capillary or film water has long been know, and that considerable quantities escafe from the soil thru evaporation is also known. Evidently during seasons of deficient rainfall the amount of water escaping by evaporation is of great importance, and it has been the attempted elimination of this 1088 thru the ure of 801 m mulches that has formed the most important feature of the plan of moisture control.

It has been commonly believed that the evaporation of moisture from the soil surface was greatly facilitated by the rise of moisture thru copillery action impelled by the laws of surface tension and capillarity. It has been thot that this rise could be rather readily controlled by the use of a soil mulch, and that where proper tillage was given to cultivated crope, this surface evacoration could quite largely be prerented. Recent investigations have created some doubta as to the importance of rapid capillary rise, as well as to the importance of the soil mulch. Leather of Indis for instance, denounces the use of the word 'capillary' in relation to soll molsture. He says, "it is true that surface tension is the 
calise of the retention of water in soils, but the term 'capillary' should be restricted to the case of a liquid completely filling a narrow space. In the upper soil, i.e., the aerated soll in which our crops develop, this condition does not exist and hence the impropriety of the term 'capillary'." Rotmistrov of Russia saye, "the less said about the capillary rise of water the better." Shantz's of the U. S. D. A., and Burx of the Nebraska Experiment Station have shown that under arid and semi-arid conditions water does not move upwards with any degree of racidity, unless the water-table is close to the surface. The view these men take is almost contradictory to the old idea of capillary movement of moisture from the lower to the upper soil layers. It is contrary to the theory upon which the use of the dry-mulch nas based.

The object in carrying out the investigation here reported has been to determine certain facts which would help to formulate the correct idea of moisture movements. The investigation not cnly includes a laboratory study of certain physical forces at work in the 8011 , but also a careful investigation of the more important question of soil moisture movements in the field. The investigation is only the initiation of a continlied study which is to be made on this question at Missouri Univeroity. 
PREVIOUS INVESTIGATIONS

Investigyticno concerned with Percolaticn and Evaroration Losseg

Dalton, as far back as 1796, constructed a percolation gauge, consisting of a cylinaer three feet deep, filled with soil, and sunk in the ground to the level of its upper edge, arrangerents being made for collecting and measuring the water which passed thru. His investicaticn extended over a period of three years and from the results he drew the deduction that $25 \%$ of the rain percolated away and that $75 \%$ wa lost by evaporation.

It is recessary to note here that this mode of experimenting, which was later adopted by many observers, such as, Maurice, Gasparin, Dickirson and Evans, Greaves, Ebermayer; ard othera, required that the soil forming the drain-gauge should be more loose and open in structure than the natural concolidated soil of a field, thus adilting a freer percolation. Care has seldom been taken to irclude the natural subsoil in the fercolation-cylinder which has generally been filled entirely with a surface soil. The surface of the gauge has again not bsen interfered with, and has sometimes becore covered by a mass of grass and weeds. The evaporation 18 of course greatly increased by the presence of this vegetation.

\footnotetext{
* A brief notice of the resulto of Maurice, Gasparin, Eberrayer, and others with a sumary of results obtaired at Fothamsted up to date, will be found in the Minutes os the proceedings of Civil Engine $\in \mathrm{r} 8$, session, 1876.
} 
During 1796 and 1797, Maurice of Geneva carried on investigaticns concerning the amount of percolation and evaporation losses of soil moisture. The procedure he foliowed was similar to Dalton's method. Cylindrical iron vessels filled with earth were used. The rainfall averaged for the two years about 26 inches per annum, 39\% of which was lost thru rercolation and $61 \%$ by evaporation.

During 1821 and 1822, Gasparin of Orange, South of France, carried on experiments somewhat similar to those of Naurice, and with an average rainfall of 28 inches per annum found that only $20 \%$ was lost thru fercolation and $80 \%$ by evaroration.

of the results obtained by the Dalton gauges by far the most extensive were those by Dickinson, Nash Mills, Hemel Hempstead, Herts, commencing in 1836*, later continued by Erans; and those commenced by Greaves at Lee Bridge in 1851, and carried on to the present time. Greaves' works will be discussed later.

Dickirson and Evans employed two drain-gauges consisting of cast-iron cylindere 3 feet in depth, and 18 inches in diamster. One wa filled with the surface soll of the neighborkood, the other with fragments of chalk; both bore a growth of grass. During the first elght years of the experiment which was conduoted by Diokinson, he found that $42.5 \%$ was lost

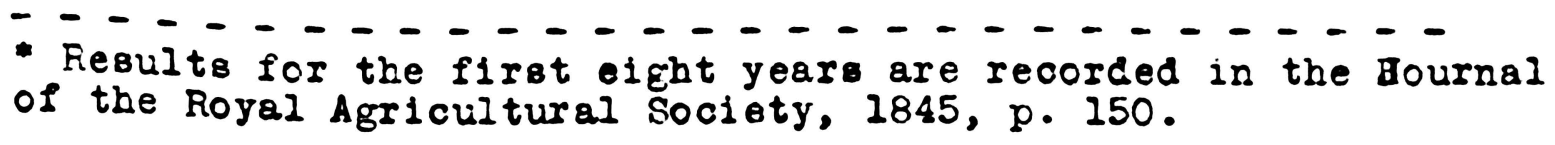


thru percolation and $57.5 \%$ by evaporation which included that due to vegetative growth. The average rainfall during the 8 years was 26.61 inches.

Evans, 1860 to 1873 , continuing the work of Dickinson found even more striking example of the disturbing action of vegetation than those of Greaves (note Greaves works below). The average rainfall during fifteen years was 25.55 inches. The summer drainage from the turfed soil averaged 0.35 inches, the evaporation 12.1.2 irches. The winter drainage was 5.23 inches, the evaporation 7.85 inches. In the whole drainageyear the average drainage was 5.58 inches, the evaporaticn 19.97 inches. The sumcer evaporation, however, actually ranges from 7.59 to 16.09 inches, and that of the whole year from 13.20 to 26.55 inches.

Lawes, Gilbert, and Warington* say, "that this wide range in the amount of evaporation was in fart due to the insufficient supply of rain. The full evacoration power of the turf has rerhaps not yet been shown, the whole of the rainfall havirg been evacorated even in the wettest summer of the fifteen jears. In these experiments the distribution of the rain has a marked effect on the amount of drainage. Rainfalla not oufficiently heavy to penetrate the turf are probably evaporated while those passing the turf apear, more or less, as drainage." In the fercolator filled with chalk, the average annual drainage was 8.79 inches, and the evaporaticn 16.76 inches.

- Journal Royal Agricultural Society, Ser. II, 17, p. 55. 
The soil no doubt being less compact in this case and the growth of grase being more vigorous than in the percolator filled with arable soll, the drainage was therefore naturally larger and the evaporation less.

During 1867 and 1868, Risler of Caleves, near Nyon, Switzerland, by using gauging drains 1.2 meters (about 4 feet) deep filled with compact and impervicus subsoil, the land being oropped as uoual during experiments found that 30\% was lost thru percolation and 70\% by evaporation. The evaporation included that due to plant growth on the surface. The average rainfall was 41 inches per annum.

Greares'* drain-gauges consisted of two square boxes made of slate, 3 feet in depth and 3 feet square; one of these was filled with sand (such as is employed for filter-beds, fassing thru a screen of 33 \#10 wires in 6 inches) to within a inches of the top, the other with a mixture of ooft loam, gravel and sand, trodden in and turfed. He had also a gauge for measuring the evaporation from a water-surface, consioting of a tank one foot in depth, and having an area of one square yard; this tank was kept afloat in a flowing stream. The tank contained a few inches of water, the rise of fall of which was ascertained from time to time. It is to be noted that Greaves' investigations were undertaken from an engineering rather than from an agricultural viewpoint and are interperted as such.

- Hinutes of the Proceedings of the Institute of Civil Engineers, session 1876, p. 53. 
Greaves' results respecting, Drainage and Evaporation

Average of 14 years, $1860-1873$.

\begin{tabular}{|c|c|c|c|c|c|c|}
\hline $\begin{array}{l}\text { Month } \\
-\ldots-\end{array}$ & $\begin{array}{l}\text { Rainfall } \\
\text { Inches }\end{array}$ & $\begin{array}{l}\text { Sand } \\
\text { inches }\end{array}$ & $\begin{array}{c}\text { Turfed } \\
\text { soil } \\
--- \\
\text { inches }\end{array}$ & $\begin{array}{l}\text { Sand } \\
\text { - - - } \\
\text { inches }\end{array}$ & $\begin{array}{c}\text { Turfed } \\
\text { soil } \\
---- \\
\text { inches }\end{array}$ & $\begin{array}{l}\text { iater } \\
\text { inches - - }\end{array}$ \\
\hline $\begin{array}{l}\text { Jan. } \\
\text { Feb. } \\
\text { March } \\
\text { April } \\
\text { May } \\
\text { June } \\
\text { July } \\
\text { Aug. } \\
\text { Sert. } \\
\text { Oct. } \\
\text { Nov. } \\
\text { Dec. }\end{array}$ & $\begin{array}{l}2.870 \\
1.596 \\
1.936 \\
1.428 \\
2.056 \\
2.205 \\
1.774 \\
2.352 \\
2.347 \\
2.730 \\
2.021 \\
2.422\end{array}$ & $\begin{array}{l}2.734 \\
1.524 \\
1.605 \\
1.117 \\
1.656 \\
1.572 \\
1.212 \\
1.783 \\
1.737 \\
2.402 \\
1.963 \\
2.173\end{array}$ & $\begin{array}{l}2.029 \\
1.085 \\
0.879 \\
0.275 \\
0.105 \\
0.156 \\
0.013 \\
0.113 \\
0.071 \\
0.515 \\
0.833 \\
1.508\end{array}$ & $\begin{array}{l}0.136 \\
0.072 \\
0.334 \\
0.311 \\
0.400 \\
0.633 \\
0.562 \\
0.549 \\
0.610 \\
0.328 \\
0.058 \\
0.249\end{array}$ & $\begin{array}{l}0.841 \\
0.511 \\
1.060 \\
1.153 \\
1.951 \\
2.049 \\
1.761 \\
2.219 \\
2.276 \\
2.215 \\
1.188 \\
0.914\end{array}$ & $\begin{array}{l}0.761 \\
0.603 \\
1.065 \\
2.098 \\
2.753 \\
3.142 \\
3.443 \\
2.850 \\
1.606 \\
1.056 \\
0.707 \\
0.574\end{array}$ \\
\hline $\begin{array}{l}\text { hole } \\
\text { Year }\end{array}$ & 25.720 & 21.478 & 7.582 & 4.242 & 18.138 & 20.658 \\
\hline
\end{tabular}

The mass of sand which fills one of the fercolators supplice an extreme example of a soll of the lowest waterholding and capillary power. The rain passes thru it without hindrance, and but little water is evarorated from the surface even in the height of summer. In the whole year the quantity calculated as evaporated amounts to but 4.242 inches. The true amount of evaporation is probably greater than this, however, as it is not very uncommon for the drainage from thi. gauge to exceed the rainfall, owing, as Greaves supposes, to condensation of water directly from the atmosphere. This excess of drainage orer rainfall occurs most frequently in Janu=ry and February. 
On the turfed soil the amount of evaporation from January to March is very similar to that observed on the bare soll at Rothamsted (note later data in regard to Rothamsted results); but Irom April to september - the growing season of the grass practically no drainage takes place, nearly the whole of the rainfall being evaporated. Drainage-water was indeed collected in July and August only on two, in June on three, and in May and Septenber on four occasions luring the fourteen yeara. The average amounts of water evaporated from the turf during summer, winter, and the whole year, namely, 11.409, 6.731 , and 18.123 inches, are very similar to those of Rothamated, probably because of the very moderate amount of rainfall supplied to the so11. In the wet aummer of $1860,15.608$ inches were evaporated by the turf in six months; and the wet season of 1872, the evaporation during twelve months reached 25.141 inches. There is thus but little constancy in the amount of evaporation, which dependa largely on the amount of rainfall, and on the activity of the vegetation. With a hoavier rainfall we should doubtless obtain more constant figures.

The figures representing the evaporation from a water surface are full of interest. The average summer evaporation 1815.892 inches; that for winter, 4.756 inches; the total for the year 20.658 inches. The amount of variation is considerable. In 1862 the annual evaporation was only 17.332 inches; in the hot season of 1868 it reached 26.933 inches. There are some obvious reasons why the evaporation 
from a water surface should be more variable tinan that from a bare soil. On a water surface sunshine and wind must always produce their full effect, while on soil, evaporation receives a check as soon as the surface is dried. Another disturbing cause in Greaves' determinations has been variable condensation from the atmoaphere, making the winter evaporations aprear lower tinan they really are.

Greaves found that in the gauge containing a mixture of soft loan, gravel and sand, trodden in and turfed, for a period of 22 years, with an average rainfall of 25.8 inches that $29.8 \%$ was lost by percolation and $70.2 \%$ by evaporation. That for tine similar gauge containing sand, during a period of 14 years and with an average rainfall of 25.7 inches, $83.6 \%$ was lost by percolation and 16.1 by evaporation.

Ebermayer of Bavaria $r$ an a series of experiments during the 12 months, March 1868 to February 1869. His gauges consisted of zinc cylinders, with an area of one square foot, and 1,2 , and 4 feet (Fr.) deep, filled with adjacent soil and exposed to air and rain for sometime to acquire normal physical charscters. He found the following reaults:

Percentage of Percolation to Rainfall

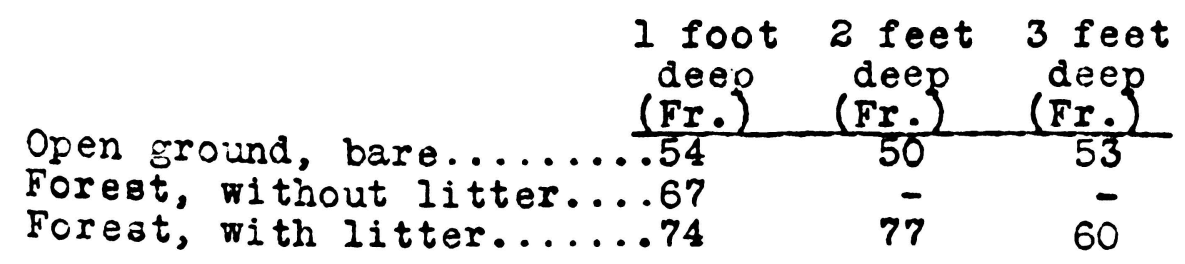

It might be noted in regard to Ebermayer's work in order to show how difficult it is to imitate soil in its natural condition, that he attempted to fill, by calculation, a number 
of tuber, 5 feet deep and 2 feet in dianeter, with the soil of the immediately adjoining field in its exact natural condition. After putting in 3 feet of soil, pouring a great deal of water thru, and applying a weight of more than one ton for many montho, the soil had not sunk down to the 3 feet by about 6 inches. It is almost impossible by artificial means to compact a soil like a natural one.

Ebermayer quotes Woldrich as having determined the amount of percolation ( 2 feet deep) thru turf, and thru bare ground, at Salzburg and in the neighborhood of Vieana. At Salzburg the percolation was

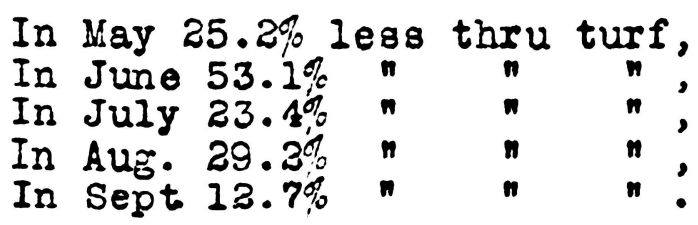

The difference was the least in January. In May, both at Salzburg and at Vienna, more than twice as much percolated thru bare earth as thru turf. From June 16 th to 30 th there percolated at Salzburg

\subsection{2 inches thru bare earth, \\ 0.02 inches thru turf.}

The maximum difference was in June and July, and less in autumn and winter. Ebermayer concluded that in the summer half-year forest soil was the moistest, bare, open ground less moist, and ture the driest.

The Rothamated gauges offer a marked step in advanco in otudying the percolation and evaporation question of soil moisture. They differ from those of Dalton, as well as all previous observers, in containing undisturbed s011, and as M11- 
ler* says in commenting on them, "soil which has been put into cyinders and subjected to the action of rain, will no doubt, as time goeo on, acquire a more and more natural condition of consolidation, but we cannot know when tilis desireable condition is completed and can only take it for granted after a considerable time. The Barnfield gauges are free from this disadvantage, and as a means of measuring drainage which is what they were mainly intended for, leave very little to be desired. As regards, however, the relation of the constituents of the drainage to those of the soil, our knowledge must always be somewhat imperfect, since it is obviously impossible to obtain exact estimates of what the soil originally contained."

In the summer of 1870, the three drain-gauges were established at Rothamsted. Each gauge consisted of an area of 1/1,000th of an acre. The soil was undermined at the desired depths $(20,40$, and 60 inches, respectively) and perforated iron plates were inserted beneath the soil to support it as the undermining proceeded. Then this was completed, trenches were then rade on the other three sides of the blocks of soil, and these were then isolated by means of $4 \frac{1}{2}$ inch brick walls.

Miller reports that the average yearly amounts of water percolating thru 20,40 , and 60 inches of soil are very similar and amount to about 14 inches, or approximately 50\% of the rainfal1. The results obtained with the 20- and 60-inch gauges were nearly identical; while the 40-inch gauge yields on

* Rothamated Memoirs, Vol. VIII, 1902-1912, p. 377. 
the average nearly one inch more drainage than the others. At Grignon, near Paris, experiments similar to Greaves' were conducted between the years 1892 and 1897 by Deherain* in a number of gauges (20), which consisted of cement tanks into which the excavated soil of the oite had been refilled; the surface and sub-soil being placed in the tanks in their natural relative positions. The soil of several of these gauges was maintained fallow, whilst on the majority variour crops were cultivated. The effect of these crops on the amount of drainage varied, but in the year 1896-7, of which the quoted records are the most complete, the amount of drainage water was from about three-fourths down to one-half of that from the fallow gauges. Thus at Grignon the ffect of the crop was very much less narked than in Greaves' experiment.

Follny** in 1894 found, in experimenting with soll from 5 centimeters to 30 centimeters deep, that the amount of drainage diminished with the depth of the 8011 up to a certain point ( 15 centimeters of soil) and then increased. The percentage increasing considerably with the depth of the soll up to 20 centimeters and then remaining fairly constant.

Four gaugea for the measurement of the amount of water which percolates thru agricultural land, were constructed by Leather*** of India at the Cawnore Agrioultural Experiment Station in 1903, and four similar gauges at the Agricultural Research Institute, Pusa, in 1906. All of these gauges were similar to those at Rothamsted, and consisted of blocks of or-

* Reported by Leather, Memolr of the Dept. Agric. Chem. Series 2, p.79 * From Wollny'a For achungen, 16, 1-14. Memoira, Dept. of Agric. of India, Chem. Series, 1, No. 5. 
dinary agricultural land measuring 1/1,000th of an acre superficially. They were isolated and walled in, and nfalse bottoms" inserted beneath them; at each station two gauges are 3 feet deep and two are 6 feet deep. Apparatus below the gauges was constreted to collect and measure the drainage water coming thru. It is noted, that in addition, the gauges at Pusa have overflow pipes connected to subsidiary tanks to take off "ourface" arainage, which is thus measured separately.

Up to 1911, Leather* reports, that, (a) the amount of drainaze and evaporation in India exhibit the same characteristics that have been met with at Rothamatod, namely, the quantity evaporating is nearly independent of the season, whilst the drainare varies with the rainfall; (b) one effect of a crop is to reduce the amount of water evaporating from the surface soil, and the Indian records have provided an eotimate of thia protective effect. A good crop, whilat itself transpires large amounts of water, will reduce $10 s 8$ of moisture in this manner to two-thirds or one-half of what it would be from fallow land; (c) the evidence of the Indian records goes to show that the water descending during wet weather passes very uniformly thru the soil and not chiefly by means of nlarger channelan" as has been commonly supposed.

At Cawnpore, India, for a five-year period, 1904-8, and with a rainfall of 31.4 inches, Leather found $38 \%$ of the rainfall percolated away, whilst 62\% evaporated, from the 6-poot gauges. In the case of the 3-foot gauges for the same reriod, 42.9\% was percolation $20 s 8$ and $57.2 \%$ evaporation 1088.

* Memoirs, Dept. of Agri. of India, Chem.Series, Vol.Ir, \#3. 
At Pusa, India, for four years, 1906 to 1910, with an average rainfall of 42.41 inches, the mean percolation was $24.61 \%$ of the rainfall and the mean evaporation $68.12 \%$ for the 6-foot fallow gauge. For the 3-foot fallow gauge the mean percolation was $29.50 \%$ and the mean evaporation $67.28 \%$.

At Cornell University*, Ithaca, N.Y., a system of cement tanks has been constructed. Each tank is about four and a half feet square and four feet deep. The tanks are sunk in the ground and a sloping bottom is provided, with a drainage channel opening into a tunnel beneath and at one side. As the tanks are arranged in two parallel rowa, one tunnel suffices for both. The sides of the tanks are treated with asphaltum in order to prevent solution. Owing to this method of construction the soil was placed in the tanks. This caused a disturbance of its structural condition which of course will make the rate of flow and compoaition of the drainage water out of acoord with field conditions for a number of yeara. Such an experiment must necessarily be one of long duration. The results obtained have not been reported, except for a few analysis made upon the drainage water.

* Science, N.Ser., Vo1. 29, No. 746, pp. 621-623. 1909. 
Investigations concerned with the Action of Capillarity

Numsrous determinations of the capillary rise of water in dry soils have been made by various investigators in the United States, as well as in forelgn countries (England, Germany, India, and others). Loughridge'g* studies on the California soils are among the best of those made in the United States. In his investigations which included adobe and silty soils, he found that the capillary rise in no case exceeded 50 inches, even at the expiration of 200 days.

King** in 1889 in investicating the capillary movement of water in a moist sand resembling quicksand, which underlies the Wisconsin Experimental Farm, found a very appreciable capillary movement of water upwards. The columns of soil were placed in water, the water-level being regulated at $1,2,3$, and 4 feet from the surface. King found water to pasa upwards at rates varying from 2.37 pounds to 0.9 pounds per equare-foot per day.

King*** in reoults from jater ex eriments discusses the data of certain investigations in which soil columns 10 feet long and with a cross section of 0.04611 square feet made of water-tight galvanized iron tubes, were exposed to drying influences for 314 days, at the conclusion of which time the 1088 of water appeared to be felt slightly at 10 feet from the surface. He says, "it is certain that a drying of these soils had taken place thru a depth of 10 feet and hence the molature

* California Agri. Exp. Sta. Report, 1892-3-4, p. 91. Tisconsin Agri. Exp. Sta., Sixteenth Annual Report, p. 203. Ibid., p. 219 . 
10 feet below the surface of the ground may become available for vegetation purposes at or near the surface! Briggs and Lapham in commenting on the results, say, "King's results do not show the capillary limit of the soil that he had under inveatigation, but show only that the capillary limit exceeded the length of the soil column used." King, also, remarks in the discussion of his results, "that it does not follow necesaarily from the experiments recorded that the upward movement here found was due to capillarity alone as it may be found that internal evaporation takes place in soils allowing water to pass up thru the soil pores of drier soils by gaseous diffusion and condenses on the colder soil grains higher up."

King* in 1905 determined the evaporation in the open from soils supplied from below with a constant water-supply, by means of large cylinders four feet in diameter and two feet deep. A shelter was conetructed within the cylinders containing a device which automactically recorded the rate of evaporation. He obtained the following results:

Soil

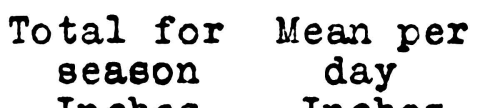

Mean per Inches Inches 1bs. per sq.ft.

Goldaboro, N.C. Norfolk

$\begin{array}{lllll} & \text { Sandy Soil } \ldots . .23 .920 & 0.212 & 1.100\end{array}$

Upper Miarlboro, wa., Norfolk' Sand .. 27.270 $0.192 \quad 0.980$

Lancaster, Pa., Hagerstown Sand .... 21.740 $0.153 \quad 0.796$

Janesville, Wis., Janesville Loam .... 25.260

0.180

0.938

* U.S.D.A., Bur. Soile, Bul. 26. 
Stewart* in investigating the capillary limito as to the beight of rise in dry and moist Michigan soils, found this limit to be wuch greater where the soil was damp.

Briggs and Lapham** found in comparing the evaporation from tubes of different lengths ( 85 and 165 centimeters, respectively) of Sea Island soil, that the shorter column showed over 5 times as much evaroration as the longer column in a period of 42 days.

Foliny*** has shom sand with $9.5 \%$ of moisture to raise moisture from a water-table one-half higher in six days tinan did tine same sand dry.

Buckingham**** in his studies on the movement of soil moisture, says, "when a moist soil dries by contact with the air above it, the loss of water is by evacoration close to the surface, the amount lost by direct evaporation ffom points several inches below the surface being, in general negligible. As the surface soil dries out, a moisture gradient is established, and the dry ourface soils draws up water from the moister below by capillary action. If this capillary flow of water be prevented or lessened, as by the use of a mulch, the escape of water is decreased, because the evaporation has on the whole, to take pace from farther below the ourface, so that it encounters greater resistance and is slower."

Leather***** after making a number of measurements showing the amount of water evaporated from the soll at Pusa

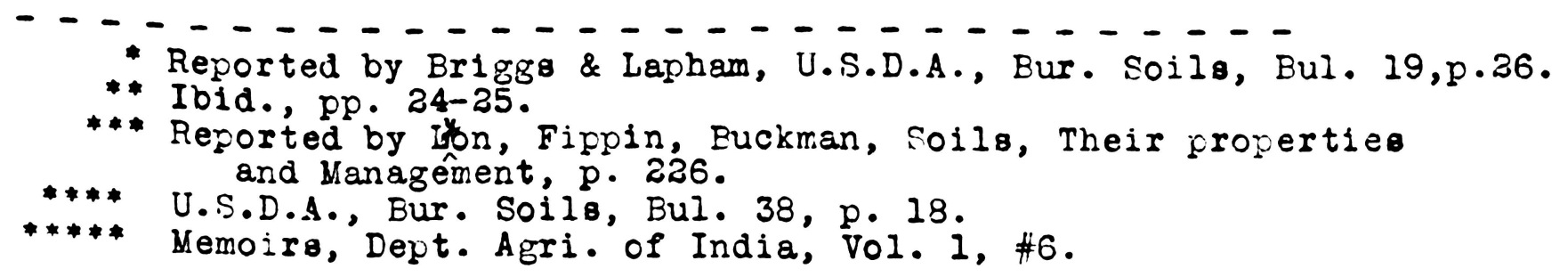


in Bengal, India, during a dry season, concludes in substance,

1. Showers effect surface only.

2. Rate of loss decreases as the depth increases, but the want of unifromity of the soil makes it impossible to get an expression showing the rate of 1088.

3. Water moves upward from a limited depth only, none coming from the seventh foot.

Alway and Clark*recentlyave $y_{\wedge}$ done some work regarding the movement of water in soils, at North Platte, Nebraska. Their work consisted of five experiments to determine,

1. The upward movement of water from moist soil into drier soil.

2. The domward movement from moist soil into drier soil.

3. The loss from saturated soil in contact with the natural subsoil in situ.

4. The upward movement in a column of soil protected from 10s below and at the sides, but fully exposed to evaroration at the surface. 5. The downward movement of rater applied to the surface of an air-dried soil.

From the results of their work they conclude that when the water content was below $10 \%$, the capillary movement of moisture in any direction was slight; but when some of the soil with a moisture content above $10 \%$ was placed in contact with the same soll containing only the maximum hygroscopic moisture, there was practically uniform movement of water from all parts of the former into the latter, - except that immediately adjoining the drler soil the change was much the greatest. The higher the water content the greater was the movement of water. Then soil with a moisture content of approximately $12 \%$ was freely exposed to evaporation from the surface no loss by capillary movement occurred to a depth of 30 inches until after the third reek, but by the end of 11 weeks the 1088 from this depth

- Nebraska Exp. Sta., 25th Annual Report, pp. 246-286. 1912. 
anounted to $1 \%$.

Rotmistrov* according to evidences from the Odessa Experiment Field, Russia, states, "that a wrong impression exists regarding the circulation of wer in an upward direction - the impression that water can rise to the surface from the deep layers of the soil by capillary action (deep layers meaning those the water of which is inaccessible to the roote of plants unless it is raised)." He contends, "that the limit from which water can make its way upward by capillary action lies much higher than the limit accessible to roots. Experiments at the Odessa Field showed thet upward movement by capillarity in a dried soil proceeded very slowly and was observed only when the bottom of the pile of soil was sunk in water. It is difficult to say how the upward transference of water is carried on in the soll under conditions of a non-saturated soil and in the absence of an available source of water in the vicinity, but there is one thing that tello in favor of the movement taking place in a state of vapor and not in the state of liquid drops, and that is, the pact that, in a strict sense capillaries do not exist in the soil. When the soil is not fully saturated with water a certain proportion of the interstices between the particles are filled with alr, and the other with water, - in consequence of which water is found in the form of separate drops cut off from one another by air. If an upward movement appeared in a significant thickness of soil, that movement could only contsin the more mobile parto, e.g., the air; ard the drops of water would re-

- Nature of Drought, p. 161 . 
main where they are, or because of their weight sink downard. ........ all these considerations, and absence of facts to the contrary lead to the conclusion that an upward movement of water only goes on in soils saturated with water; whereas, those in a non-saturated condition suffer a loos of water wherever a drop lies, by evaporation into the air surrounding that drop. For tinis reason the loss of water in the superficial soil layer goes on very slowly even when the layer is in a compact condition."

Alway* after careful otudy in regard to the circulation of non-available water in to the hygroscopic coefficient concludes, "that the loss of water from the subsoil of ary lands under crop seems to take place almost entirely thru transpiration. In the absence of plants the loss from the subsoil is small. The stored moisture of the diffent deptho of subsoil in the field becomes available to plants by the roots being developed into these deptho, but little moisture being elevated to the roots by capillarity ....... The amount of water retained by a soil saturated in pots or cylinders is far in excess of the amount retained by a similar soil saturated in a field where the water-table is at a considerable depth below the ourface as in ordinary dry-land."

Burr** of the Nebraska Agricultural Experiment Station after making a study of the problems relating to a greater use of the water that fallo upon the lard in Festern Nebraska, concludes along with other conclusions, the following:

* Neb. Agri. Exp. Sta., Reaearch Eul. 3, p. 121. Ibid., Research Bul.' 5, rp. $9-10$. 
1. That capiliarity is an effectrial agent within certain limito, when operatirg close to a supply of free water. It may be an importart factor in crop production where sheet water is close to the lower limits of the soil zone occuried by the rocts of the crop. 2. Away from a source of free water and in a soil partially dry, capillary moverient has not been detected. 3. Fater supply by capiliarity is not an important factor in crop production on Nebrakka upland soils.

He, 8lso, atates, "that the moverent of water thru the soil by capiliarity is so slow that it is practically useless in bringing water from a lower soil area for the use of a growing crop. The rapid use of water by crope, eqpecially during eeasons of drouth and increased transpiration, requires rore rater than can be suppiied by capiliarity. planta will suffer end aie under extreme conditions after having used the available water within reach of the roots, even tho there is additional water in the soil immediately below: Shantz of the U.S.D.A., Bur. of Plant Industry, stated in a lecture auring the summer school session of Nissouri University, 1915, "that soll moisture in these so1ls referring to the soils of the dry land regions - does not move upward, as we have hitherto supposed unless the watertable io very close." Dr. Shantz found in hio inveotigationo, that wheat had utilized the soil moisture to a depth of four and one-balf feet and that at the time observations were rade, the soil moiature below this decth was higher than that in soll in which the roots had been feeding. He said, "if there ia anything in the $01 d$ ideas we have fonded recarding cau1luary tubeg, the moisture in the soil at deptho 
of five and six feet rould have moved upwards to give equal distribution, but this was rot the case." 
Investigations concerned with Run-off I0s8

of all the problems that have to do with a study of the relation between water and soil, probably the question of surface drainage is the most variable and the most cifficlit to determine. The factors that go to control it are of such a character, that it is impossible to find the exact errount. However, this is no reason for entirely neglecting the rossibility of measuring its magnitude, especially when such an estimate is made under well controlled conditiono.

Up to the present time, it is not known that any experiments have been attempted by which the actual percentage of run-off from land under definite treatment has been determined. Many rough estimates have been made of the percentage of surface drainage and the amount of surface erosion it may thereby cause. Geologists for a number of years have eatimated the percentage of run-off from large drainage areas, and have calcliated how lone it will take the mountaing, plateaus, and plains of the earth to be worn down to sea level. The fer cent of rainfall leaving the land as run-off and discharged by rivers varies with the arount and rapidity of the rainfall, the olope of the drainege area, the texture of the soil and mantle rock, the vegetative growth present, and other factors. Norton of Cornell University says, "with an arnual rainfall of fifty inches in an ofen country, about $50 \%$ is discharged; while with a rainfall of twenty inches orly $15 \%$ is discharged, part of the remainder being evaporated, and fart

- Elements of Geology, p. 55. 
passing underground beyond the drainage area. Thus the Chio discharges $30 \%$ of the rainfall of its basin, while the Hissouri carries away but 15\%. A number of the etrears of the semi-arid lands of the Test do not discharge more than $5 \%$ of the rainfall."

The late Dr. Hilgard* of the Univergity of Californik, says, "this fortion (the run-off) of the disposal of rain may range all the way from nothing to almost totality, according to the nature of the soil and the condition of its surface.......n

Toumey** states that, "in the San Bernardino nountains in southern California, the first rainfall (in Decenber) was absorked to the extent of $95 \%$ in forested areas, against only $60 \%$ in the non-forested; but that later, after the 8011 had been partisly saturated, $60 \%$ only was absorbed in the forested land, against $5 \%$ in the non-forested. While it is generally adnitted that forests aiminish the run-off, Rafter*** contends that in New York gtate the reverse is true."

Leather**** in his evaporation and drainace studies has tried to make a study of the surface drainage from his gauges. During 1509 with a rainfall of 46.23 inches, he obtained the following results:

No. cf Gauge Condition Amount of Surface Percent of Rainfell

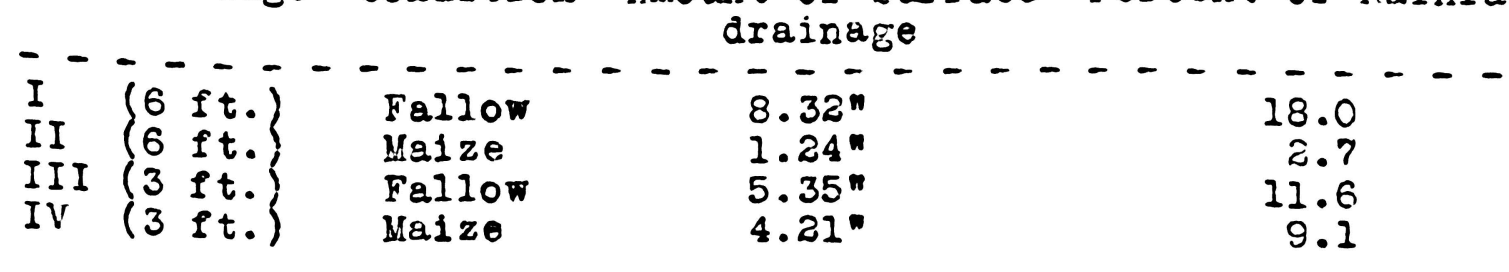

* So118, p. 216.

* Ibid., p. 216. U.S.D.A., Yrbk., p. 287 . 1903. Memoirs of Dept. Agri. of India, Chem. Series, Vol. II, \#2. 
Leather emphasizes the point that the surface drainage from land is not neariy as large as the usual practical agriculturiat estimates. However, it will be observed from the results obtained in this inveatigation that Leather has no doubt uncerestimated this 108s, and that the loss due to surface run-off is a very important factor, as least when the matter of erosion of the valuable humus layer is considered. Rodhouse* in his preliminary studies on the water resources of Missouri, has obtained some very interesting results on drainage areas of considerable size. He found that Grindstone creek near Columbia, Missouri, with a watershed of 14.7 square miles during 1910, with a rainfall of 42.22 inches, had a total run-off of 15.74 inches, or a ratio of run-off to rainfall of 37.3 per cent. Also, during the first six months of 1911, with a rainfall of 13.05 inches, a run-cff of 3.33 inches resulted, or a ratio of runoff to rainfall of only 25.5 per cent. In studying the monthly discharge of Current river at Van Buren, Missouri, from August 25, 1912, to November 30, 1914, with a drainage area of 1812 square miles, he found thet the ratio of run-off to ralnfall during this period was 21.48 per cent.

* 10. Engr. Exp. Sta., Serieg 15, No. 33, pp. 11 and 27. 
PLAN AND SCOPE OF INVESTIGAION.

The plan of the investigation here rerorted ircilides a study of the per cent of water fenetration, runoff, evaccration, percolation, and amount of erosion, taking place under field conditions, with cultivated and uncultivated land. Also, a study of the capillary movement in evaroration, as well as how soil moisture is effected by the force of gravity.

A part of the investigation vas carried out under laboratory and greenhouse conditions, while the major part was carried out under actual field conditions and surroundings.

The laboratory experinents consiated of a study of the depth of the water-table as effecting evaporation 108 and capillary rise of moisture in a soil, and the gravitational effects on capillary noverents of soil moisture.

The field experiment consisted of a study of the per cent of water penetration, run-off, evaporation, percolation, and amount of erosion, taking place upon four definite areas of grouwid(two of which were enclosed) under field conditions and abject to cultivated and uncultivated treatnents. A study was made of the moisture movements from the time the water reached the soil as rain, until it left the soil as an unabsorbed excess - run-off, or as gravitational water - percolation, and as water vapor - evaporation.

In addition accurate records were kept of the amount of rainfall, the wind velocity, and water-free-aurface evaporation at this location during the period of the experiment. 


\section{LAEORATORY EXPFRIMENTS.}

\section{Experiment. I.}

Dexth of water-table as effecting caciliary rise of moisture in the soil and evaporation losses.

A study of the capillary rise of soil moisture was made under as icieal conditions as posible in the laboratory. A constant water-table was naintained at the base of the soil columns ard a moist soil was used to begin with, both of which ohouid be in favor of the action of capillarity. The $108 \mathrm{~s}$ from the water-table up into the soil columno was deternined accurately, as well as the loss thru evacoration from the soil surface.

It is realized in undertaking a study of this kind tinat many things must be taken into consideration, and that where only one type of soll is under investigation, it is only possible to draw conclusions in a general way as to soila of different types with varying textures. However, where a careful study is made of the principles underlyirg and the factora controlling moisture movements in one tyce of soil with a definite texture, the oane principles must be more or less true in other types.

R. W. MeClure of Missouri University initiated this investigation thru the advice of Professor M. F. Miller, and is to be given credit for collecting the data reforted in Experiment $A$. 
Experiment A.

Plan of Experiment -

The method of carrying out this experiment was to place a soil in cylirders of variolis heighto, so constructed that a permanent water-table could be provided at the base thereby furnishing the maximum and ideal conditions under which carillarity may act. The soil was gut in the cylinders so as to represent field conditions as nearly as possibie, and by weighing at intervals and weasuring the anount of water taken up from the water-table below, the amount of water being lost thru evaporaticn could be compared with the amount taken into the soil be capillarity from the water-table below.

Accordingly, six galvanized iron cylinders of the design shown in Plate $I$, and 6 inches in diameter, were constructed, these being arranged in three series 2,4 , and 6 feet in height respectively. The lower ends were encircled by a cylindrical tank, 4 inches high and 10 inches in diameter, soldered onto the inner cylinder in such a way that the floor of the tank supported the inner cylinder. A screw-cap opening placed at "C" allowed for the addition or measurement of water. The lower portion of the cylinder "An", which was to be filled with soil was perforated with sixteen one-fourth inch holes arranged in two rows of eight each, the rows being onehalf inch and two inches from the bottom. This allowed for free passage of water from the water-tank " $B$ " into the soil column, thus providing a permanent water-table. To the top of each cylinder were riveted two iron hooks by which they could 
PLATE-I.

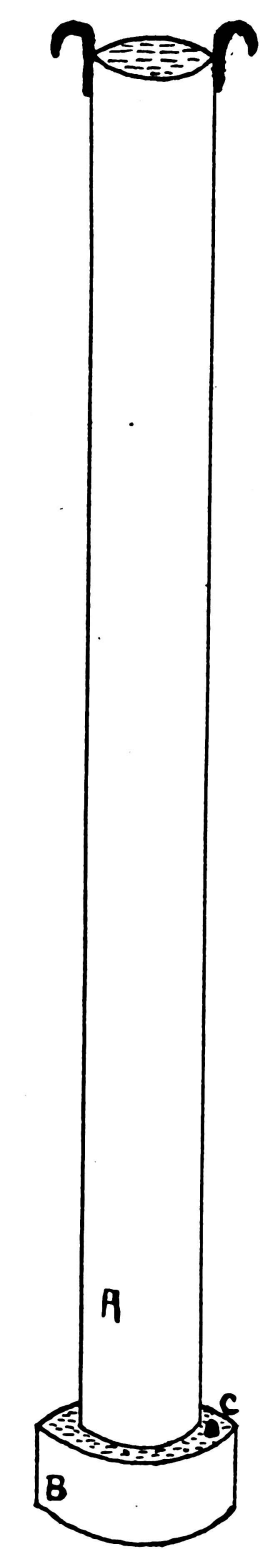

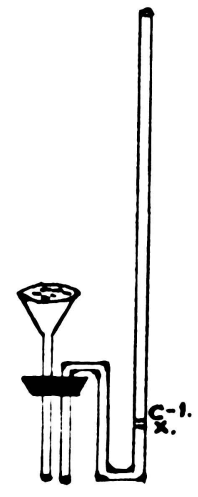

Fia. 1 - Sorl Cylin def.
FIG.2-SIPHON.

$$
E w^{n}=1 \text {. }
$$


be lifted in weighing.

Since the experiment was started in the late winter and the subooil in the fields was not in a fit condition to bandle, it was not possible to put soil into the cylinders in the actual field condition. It was trot best to live a surface soil thruout the whole derth of the cylinders for this first experiment, and if striking results were secured, to attempt to secure the soil in its actual field condition later.

The soil used was the surface foct from the plowed land just South of the Agricultural Builaing; it was a silt loam containing considerable organic matter. As the ground was covered with snow at this time it was necessary to dry the soil in the greenhouse. About 50 pounds was taken to the laboratory to determine the proper amount of water it should contain and the amount of tamping necessary to obtain a field condition as near as possible in regard to compactness. Experiment showed that $17 \%$ was about the proper moisture content, so the remaining soil was dried to that per cent, sifted thru a 4-mesh seive and thoroly mixed. It wa covered seclirely with oil-clcth to insure its remaining at thio moisture content until all cylinders were filled.

Because of the possibility of the compact soil clogging up the perforations in the lower part of the cylinders, a small amount of gravel was placed in the bottom of each, enuf to extend above the top of the second row of holes. This allowed for free percolation of water from the outside water tank into the interior cylinder conteining the 8011 . The cylinders were ighed empty and with the gravel 
in them. The plan used in putting in the soil was to put two small sccopfuls into the cylinder, fut in the tamp and turn it lightly several times to level the soil then tamp 20 times, using a plunge of approximately two inches, and with as nearly as possible the same amount of force each time, so as to secure uniform compactness.

As the first cylinder in each series was filled it was weighed and the amount of soil in it recorded so that an equal or nearly equal amount could be weighed out for the duplicate in the series. The cylinders were filled level full, weighed, and cloth covered tenporarily to prevent eacape of moisture.

To each water-tank was immediately added 3,000 cubiccentimeters of water, and the total weight of cylinder, soil, and water secured. Daily observations were made of the height of water in the cylinders to determine the axount passing up into the soil column. It was thot that by allowing the cylinders to stand thus for about three weeks, the water would tend to becomentequalized thruout the duplicates than would be the case if the experiment was started at once. The height of water in the tanks was measured by means of a metal rod and a meter-stick.

After a week the cylinder were weighed to determine if any 1088 of molsture had taken rlace. Practically no 1088 had occurred, and the height of water in the tanks was not noticeably changed. More water was added to each cylinder till it stood at a height of $35 / 16$ inches. The cylinders were again weighed and tightly covered with paraffined paper. 
Dafly observations continued to be made regardire the height of water, weighings being made at intervals of eight days. It was found that the soll column was taking up but little more water from below, so the paraffined papers were revoved and the weighings to determine the moisture loss were begun.

\section{Experimental Methode -}

The cylinders were weighed on a flatform balance, the method of lifting then being by means of a chain and pulley supported on a trestle. They were weighed accurately to within a quarter of an ounce every two or three days. After the experiment had been running a couple of days the soil at the surface seemed to shrink in, leaving a slight orack between the soil colurns and the cylinders; cracksalso appeared on the surface. All of these openings were shaliow and were filied in by scraping soil from the aurface into them and compacting with a stick, so that the water would necessarily need to pass thru surface soli instead of escaping thru soil fissures. When the water in the tanks apeared to be getting close to the two-inch wark the cylinders were refilled, the old and new weights betng recorded together with the new height of water.

Experimental_data -

The results secured from April 10th, to lay 19th, 1915, are as. follows: 
Table 1. - Inches of Water absorbed by Soil Columns.

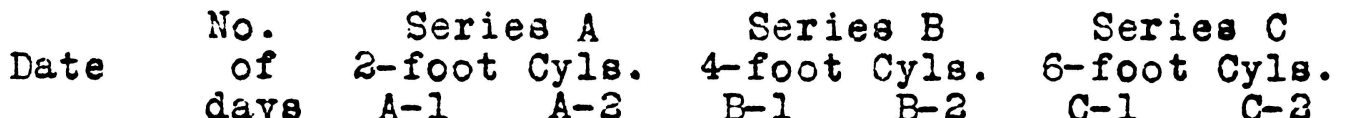

$\begin{array}{llrrrrrr}4 / 10-4 / 18 & 8 & 9 / 16 & 18 / 32 & 3 / 32 & 3 / 32 & 1 / 32 & 2 / 32 \\ 4 / 18-4 / 26 & 8 & 6 / 16 & 11 / 32 & 4 / 32 & 7 / 32 & 2 / 32 & 2 / 32 \\ 4 / 26-5 / 3 & 7 & 11 / 32 & 11 / 32 & 1 / 32 & 0 & 0 & 0 \\ 5 / 3-5 / 10 & 7 & 3 / 16 & 8 / 32 & 6 / 32 & 4 / 32 & 1 / 32 & 1 / 32 \\ 5 / 10-5 / 19 & 9 & 6 / 16 & 13 / 32 & 2 / 32 & 6 / 32 & 1 / 32 & 0\end{array}$

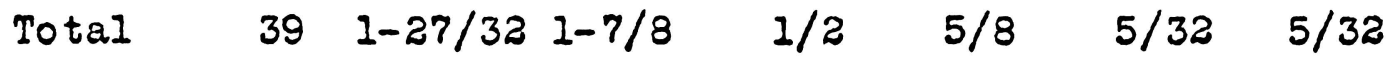

$\begin{array}{lllllll}\text { No. of cuin. } & 93.04 & 94.63 & 25.24 & 31.54 & 7.83 & 7.89\end{array}$

ivo. of ouncer $53.84 \quad 54.75 \quad 14.60 \quad 18.20 \quad 4.55 \quad 4.55$

Ave. cuin.per series $93.81 \quad 28.40 \quad 7.83$

Ave. ounces per series $54.30 \quad 16.40 \quad 4.56$

Table 2.-- Ounces of Fiater lost from So1l Columna.

No. Series A Series B Series C

Date of 2-foot Cyls. 4-foot Cyls. 6-foot Cyls. day $A-1 \quad \mathrm{~A}-2 \quad \mathrm{~B}-1 \quad \mathrm{~B}-2 \quad \mathrm{C}-1 \quad \mathrm{C}-2$

$\begin{array}{llrrrrrr}4 / 10-4 / 18 & 8 & 19.75 & 19.75 & 12.00 & 12.50 & 11.75 & 11.25 \\ 4 / 18-4 / 26 & 8 & 7.75 & 7.50 & 4.00 & 5.35 & 2.25 & 3.50 \\ 4 / 26-5 / 3 & 7 & 5.00 & 5.75 & 5.35 & 4.00 & 2.50 & 1.50 \\ 5 / 3-5 / 10 & 7 & 8.50 & 8.00 & 1.75 & 2.75 & 3.00 & 5.50 \\ 5 / 10-5 / 19 & 9 & 10.50 & 11.00 & 4.25 & 4.00 & 2.75 & 2.75\end{array}$

$\begin{array}{llllllll}\text { Total } & 39 & 51.50 & 52.00 & 27.25 & 28.50 & 22.25 & 24.50\end{array}$

Ave. ounces per series $51.75 \quad 27.88 \quad 23.38$

Table 3. - Ouncea of water lost compared with ounce of water absorbed.

\begin{tabular}{|c|c|c|c|}
\hline Serieg & $\begin{array}{l}\text { Ounces } \\
\text { lost }\end{array}$ & $\begin{array}{l}\text { Ounces } \\
\text { taken up }\end{array}$ & erence \\
\hline & & & \\
\hline$\left\{\begin{array}{l}2- \\
4-\end{array}\right.$ & $\begin{array}{l}51 . \\
27 . \\
23 .\end{array}$ & $\begin{array}{r}54 . \\
16 . \\
4 .\end{array}$ & $\begin{array}{ll}\text { plus } & 2 \\
\text { minus } 11 \\
\text { minus } & 18\end{array}$ \\
\hline
\end{tabular}




\title{
PLATE-II
}

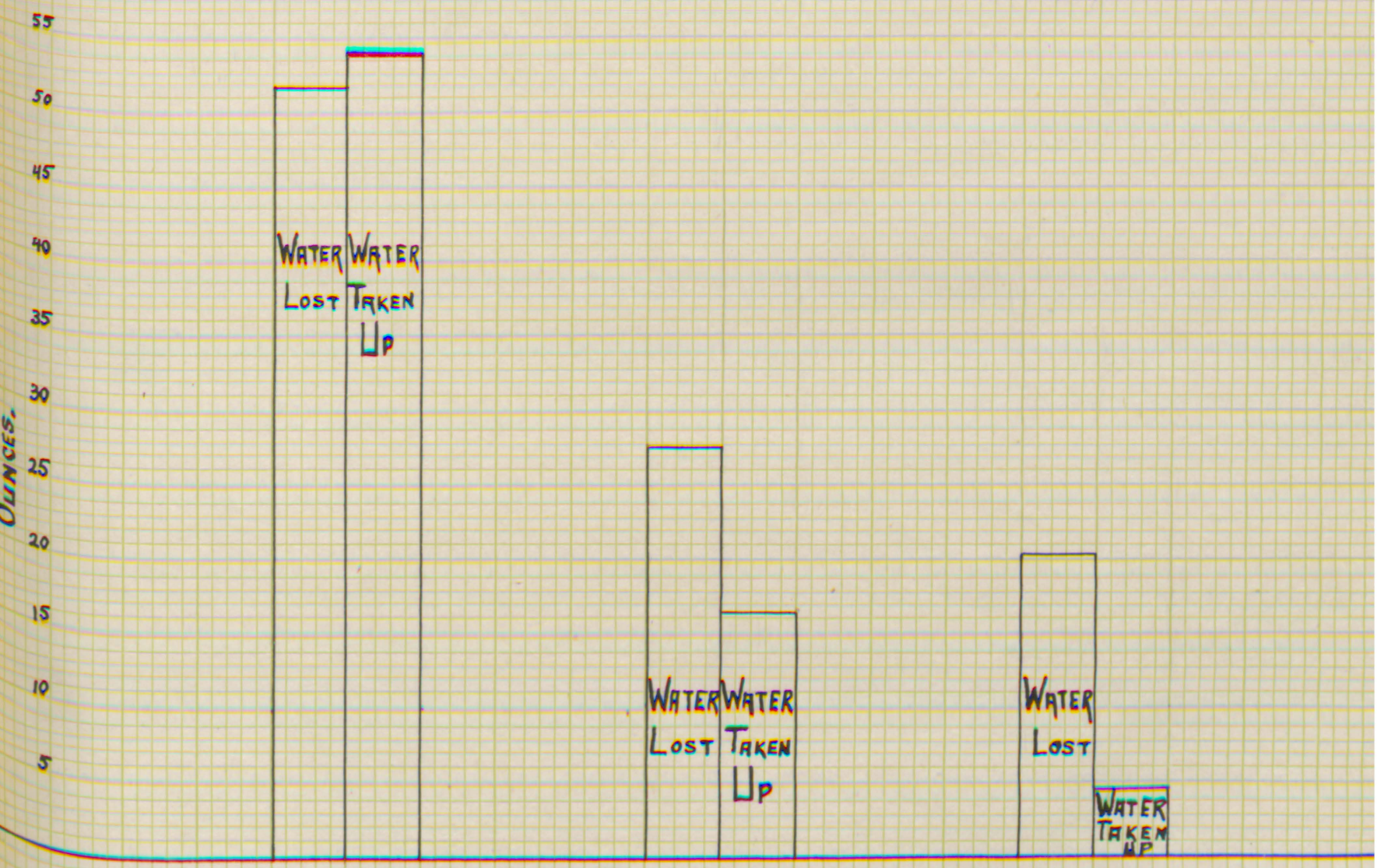

Two Foot Columns. Four foot Columas. Six foot Columns

\author{
EVAPORATION LOSS \\ COMPAREO WITH \\ WATER-TRBLE LOSS.
}


Table 4. - Los3 of Water per Acre per Sexies for 39 Days.

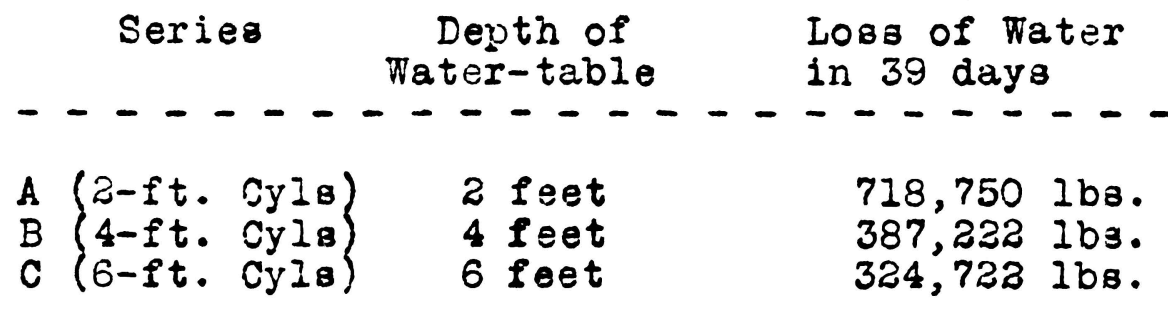

General Observations -

Table I show the actual amount of water that has passed up into the soil columns, calculated both in terms of cubic-inches and of ounces. It is shown that the greatest amount has been taken up by Series $A$, the 2-foot columna; the amount has dropped considerably in Series $B$, the 4-foot columns; and, is still less in Series $C$, the 6-foot columns. In Series $A$, wile water appears to have been taken up most rapidy during the first reek, still a more or lese uniform amount was taken up in subsequent weeks. In Series $B$ the rate was not nesrly so rapid nor so regular. In Series C practically no water was taken up after the first two weeks. Table 2 shows the actual smount of water lost from the columns by surface evaporation. The loss occurs in the same order in which water was taken $u_{\text {, }}$ tho not in the ame proportion. By far the greatest amount of evaporation has taken place in Seriea $A$. In all series the greatest amount of evaporation took place during the first week, a sharp demarsation being noted between the loss the first week and those thereafter, showing that the surface soil was drying rapidy during thyt time. 
Table 3 shows a cormarison of the amount of water lost by evaporation from the surface and the amount taken up from the water-table. It will be noted tinat in series $A$ the amount of water taken up by the soil column in five weeks was 2.34 ounces in excess of the amount lost by evaporation, so this soil must have been in a slightly more most condition at the end than at the beginning of the experiment, at least near the bottom of the column. In botin $B$ and $C$ series, however, considerably more had been lost by evaporation than had been taken up, - the difference being 11.5 ounces in series $B$, and 18.9 ounces in Series C. In Series B the soil had taken up slightiy more than half as much as it had lost. In Series $C$ it had taken up only about one-fifth as much as it had lost, most of this being taken up during the first two weeks of the experiment which shows that the lower soll was not capillarily saturated when the water was added in the jacket, and that it took up enuf to resch cspillary equilibrium in the lower layers, but that very little if any passed ugward in the entire length of the column.

\section{Experiment $B$.}

After the above reading were obtained by McClure, the cyliniers were allowed to remain in the greenhouse during the sumrer of 1915. Water was kept in the tanks at the bottoms of the columns to prevent undue evaporation, as well as to prevent the soil column from becoming dry and hard. 


\section{Experimentals Methods -}

A little moss was found growing upon the surface of each of the cylinders on Sept mber 25 th which was killed by a few drop of a dilute solution of coprer sulphate. It was then removed by scraping the surface and removing approximately one-eightin of an inch of the soil surface.

In order to insure thit the soil colunns would be in ideal condition for water movement to take place, each colurn was saturated with water. This was brought about by maintaining a conatant drizping of water onto tine columns for several days or until it was observed that all the columns were loosing water thru the opening "C" (see PlateI, fig. I), the covsring of which had previously been removed. As soon as the columns were aturated approximately one inch of witer was removed by sickn from each tank. This brought the water to the same level in all the tanks, after which, initial weighings were made and this second experiment started.

A different method was used in determining the water I0в fron the water-table and in the maintenence of a constant water-level, than was used in Experiment $A$. Sipbon as shown in Plate I, fig. 2 , was used. It was marked at "X" showing the height of tine water-tables in all the cylinders at the beginning. At each weighing by using a 100 cubic-centimeter graduated cylinder the proper numb $r$ of cubic-centimeter of Hater was added to bring the water up to the maris " $X$ " - the initial water-tabie level. This amount was recorded as the amount that had been lost from the water-table thru capillarity. In order to compare this 1039 to the evaporation 1038 
it was converted into ounces by using 28.35 cubic-centimeter equal to one ounce. In the weighing of the cylinder 8 , the o:me platform balance (Fairbank's) was used as in Experiment A, which was accurate to a quarter of an ounce. After the experiment was well underway, readings were made once a week, on the same day and hour.

All thru Experiment $B$ evaporation readinge from a free-water-surface were taken. A porcelain jar, ten inches in depth and with approximately the same ourface area as the soil columns was used. A pointed steel rod, mounted on a square galvanized iron base, was used to indicate the exact height of water surface. The numbrr of cubic-centimetera necessary to bring the water-level up until the point just broke the surface film was recorded as the evaporation los for the previous period. All r ading were made at the time of weighing tine cylinders. The jar was situkted on a table near the soil columns, in order that the factors affecting it would be the scme as for the soil.

The cylinders occupied the same position in the greenhouse during the entire period. On May 15th, 1916, the greenhouse was whitewashed and the sun's rays excluded to some extent. The effect is seen in the lessened evaporation 108 s from the free-water surface on the weck ending May $20 t h$, in comparison with that for the week ending May 13 th.

Almost inmediately after the experiment was started the same difficulty was experienced as in Exooriment $A$, in that the soil at the upper surface of the cylinders seemed to shrink away from the sides, leaving a elight crack between the soil and the cylinder wall. Cracks appeared, also, in the ourface 
of some of the cylinders. All these openings were shallow and were filled in by scraping soil from the surface into them and compacting with a stick, so that the entire loss of water should take rlace thru the soil. This had to be done several times during the courge of the experiment.

On April 15ti, 1916, the surfaces of all the columns were scraped and a small amount of soil removed from each. For sometime previous to this it was noticed that a white layer of salts was collecting on the surface of all the columna, particulariy on tiose of the 2 - and 4-foot lengthe.

Experimental data -

The following pages contain tables of regults obtained. 
Table 5. - Ounces of Nater absorbed by Soil Columne.

Date

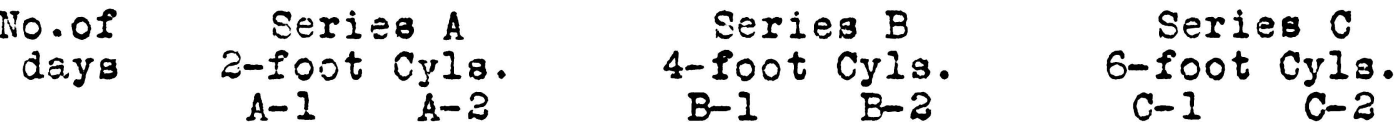

1915

Oct. 29 Exceriment started.

Nov. 13

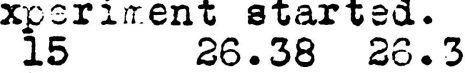

$20 \quad 7$

Dec. $\begin{array}{rr}4 & 6 \\ 11 & 7 \\ 17 & 6\end{array}$

$5.18 \quad 5.17$

6.007 .51

2..18 3.28

4.626 .49

$\begin{array}{ll}17 & 6 \\ 24 & 7\end{array}$

$2.64 \quad 3.52$

1916

$\operatorname{Jan} \begin{array}{rr}8 & 15 \\ 15 & 72\end{array}$

Feb. $\begin{array}{rr}29 & ? \\ 5 & ?\end{array}$

$\begin{array}{rl}5 & 7 \\ 19 & ?\end{array}$

Mar. $\begin{array}{rr}26 & 7 \\ 1 & 7\end{array}$

117

187

Apr. $\begin{array}{rr}25 & 7 \\ 1 & 7\end{array}$

8
15

227

way $\begin{array}{rr}29 & ? \\ & 6\end{array}$

13 ?

207

June $\begin{array}{rr}27 & ? \\ & 3\end{array}$

$10 ?$

$17 ?$

15.23
3.55
5.12
3.03

5.22

5.64

6.98

4.09

5.01

6.42

3.24

5.54

5.04

4.69

3.49

3.21

3.52

17.32

6.56

6.14

4.11

7.05

6.46

6.27

7.05

5.01

7.58

4.58

5.08

5.29

5.34

3.49

2.90

3.42

4.34

5.39

4.07

4.02

4.30

3.10

5.36

3.37

2.89

3.10

3.52

1.98

3.52

4.94

$1.38 \quad 2.82$

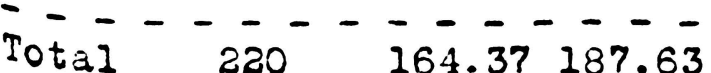

$2.43 \quad 4.23$

$3.03 \quad 2.29$

$0.76 \quad 2.12$

0.951 .38

$2.05 \quad 2.43$

$0.70 \quad 1.87$

$0.75 \quad 2.29$

$2.57 \quad 2.75$

$\begin{array}{rr}0 & 0 \\ 2.75 & 3.52\end{array}$

$0 \quad 1.09$

$2.99 \quad 3.52$

3.10

3.49

2.79

2.71

0

0
0

2.61

0.39

4.34

1.80

0.64

3.40

1.73

0.78

1.16

1.27

1.52

1.38

2.15

1.50

1.09 1.80

4.51

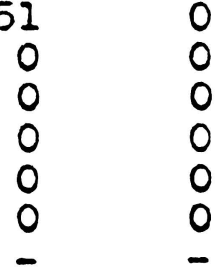

0
0
0
0
0
0
-

$-1 . \overline{7}-\cdots$

$0 \quad 0$

$0 \quad 0$

$0 \quad 0$

$\begin{array}{lll}0 & 0 \\ 0 & 0\end{array}$

$0 \quad 0$

$0 \quad 0$

$0 \quad 0$

0

1.96

0

0

0

0

0

$0 \quad 0$

$0.64 \quad 2.79$

$0 \quad 1.38$

0

$0.84 \quad 0.90$

$1.00 \quad 0.87$

2.812 .05

00

0

$0 \quad 0$

$0 \quad 0$

$\begin{array}{llll} & 44.77 & 69.02 & 11.75\end{array}$

Ave. ounces per series 176.00

56.90

9.38 
Table 6. - Ounces of Water lost by Soil Columns.

\begin{tabular}{|c|c|c|c|c|}
\hline $\mathrm{Da}$ & $\begin{array}{l}\text { No. } \\
\text { of } \\
\text { days }\end{array}$ & $\begin{array}{c}\text { Series } A \\
2-\text { foot } \\
A-1 \\
A-2 .\end{array}$ & $\begin{array}{c}\text { Series } B \\
4-\text { foot } \\
B-1 \\
\text { Cyla } \\
\text { B }-3\end{array}$ & $\begin{array}{c}\text { Series C } \\
\text { 6-foot Cyla. } \\
\text { C-I }\end{array}$ \\
\hline
\end{tabular}

1915

Oct. 29 Experiment started.

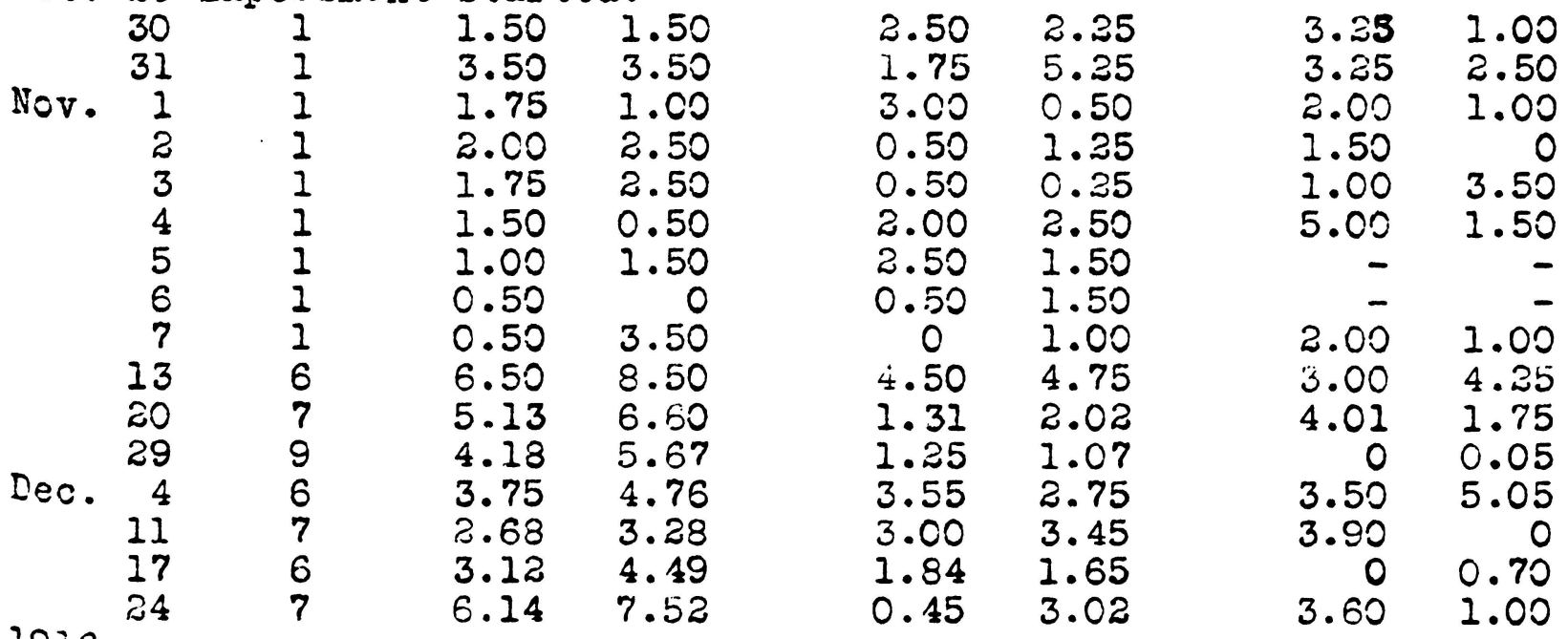

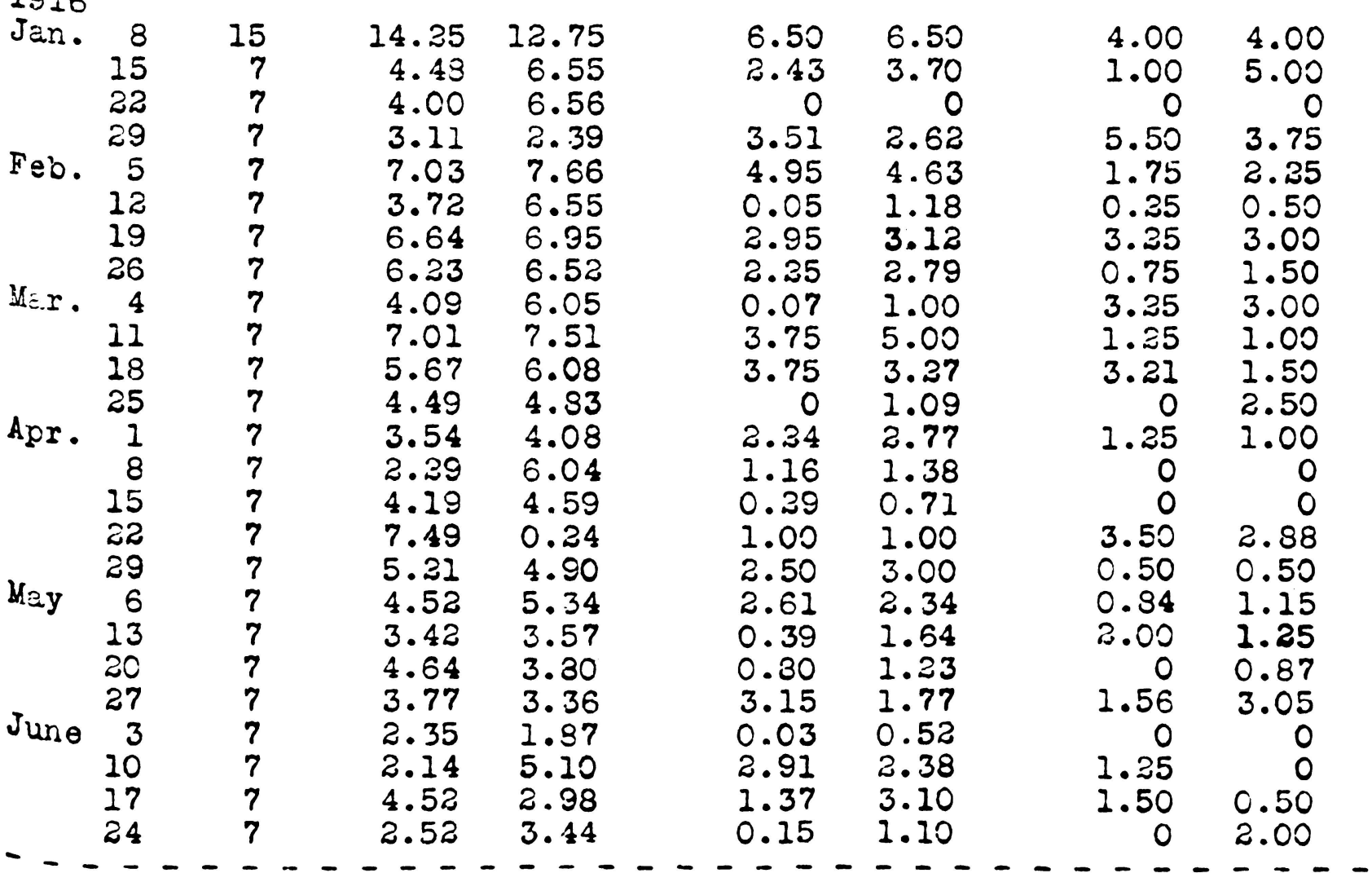

Total $220 \quad 166.82187 .03$

Variation in duplicates 20.31

Ave. ounces per series 176.92

Ave. rounds yer series $\frac{17.96}{11.06}$

\begin{tabular}{|c|c|}
\hline 77.96 & $\begin{array}{l}92.55 \\
14.59 \\
85.25 \\
5.33\end{array}$ \\
\hline
\end{tabular}


Table 7. - Ounces of Water lost in Quarter Periods.

\begin{tabular}{|c|c|c|c|c|c|c|}
\hline & Ser & $8 \mathrm{~A}$ & Seri & & $\mathrm{Sez}$ & \\
\hline Quarter & $\begin{array}{c}2-100 \\
A-1\end{array}$ & $\begin{array}{c}\text { Cyla. } \\
\mathrm{A}-2\end{array}$ & $\begin{array}{c}4-f 00 t \\
A-1\end{array}$ & $\begin{array}{c}\text { Cy } 18 . \\
A-2\end{array}$ & $\begin{array}{c}6-100 \\
A-1\end{array}$ & $\begin{array}{c}\text { Cyls. } \\
A-2\end{array}$ \\
\hline & 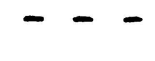 & -- & - & 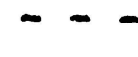 & - & - \\
\hline $\begin{array}{l}1 \\
2 \\
3 \\
4\end{array}$ & $\begin{array}{l}52.50 \\
42.46 \\
43.98 \\
27.88\end{array}$ & $\begin{array}{l}63.32 \\
49.93 \\
44.32 \\
29.46\end{array}$ & $\begin{array}{l}32.15 \\
19.54 \\
14.76 \\
11.41\end{array}$ & $\begin{array}{l}37.71 \\
21.54 \\
19.22 \\
14.08\end{array}$ & $\begin{array}{r}38.01 \\
10.00 \\
17.46 \\
7.15\end{array}$ & $\begin{array}{l}.30 \\
.90 \\
.38 \\
.92\end{array}$ \\
\hline
\end{tabular}

$\begin{array}{lllllll}\text { Total } & 166.92 & 187.03 & 77.96 & 92.55 & 72.52 & 64.50\end{array}$

Table 8. - Water loat compared with Water absorbed.

Series Ounces Ounces Difierence
lost absorbed
A (2-ft. Cyls.) 176.92
B (4-ft. Cyls.) 85.25
176.00
56.90
0.92
68.56
28.35
58.68 


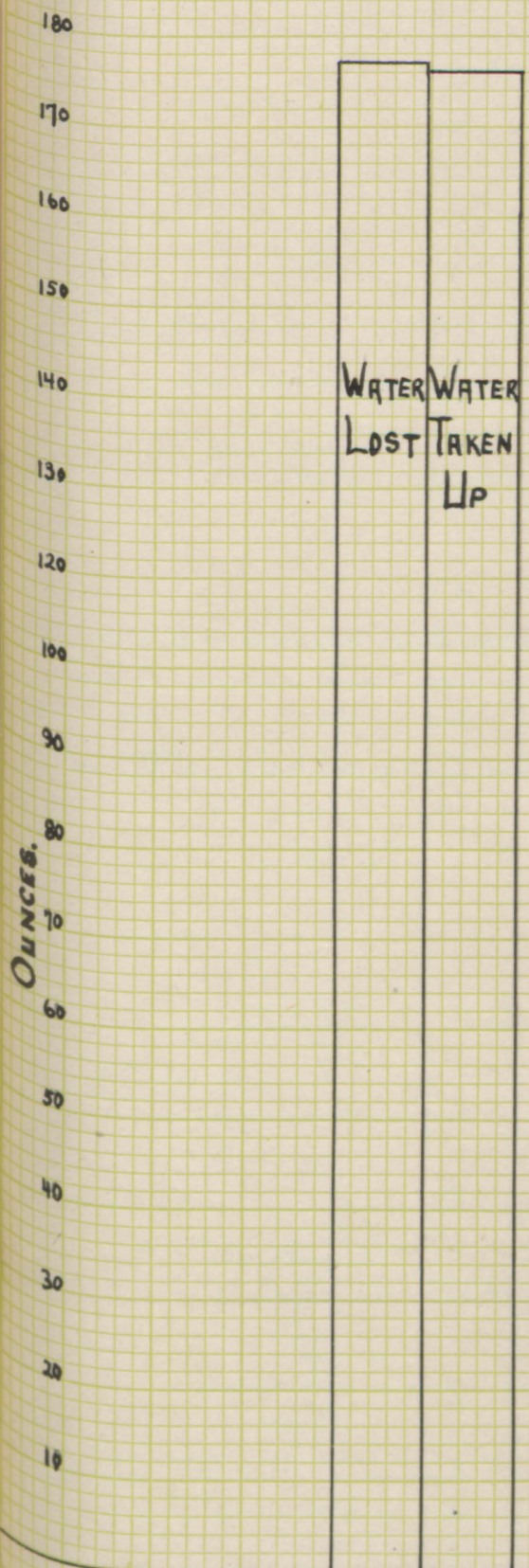

\section{PLATE-III}
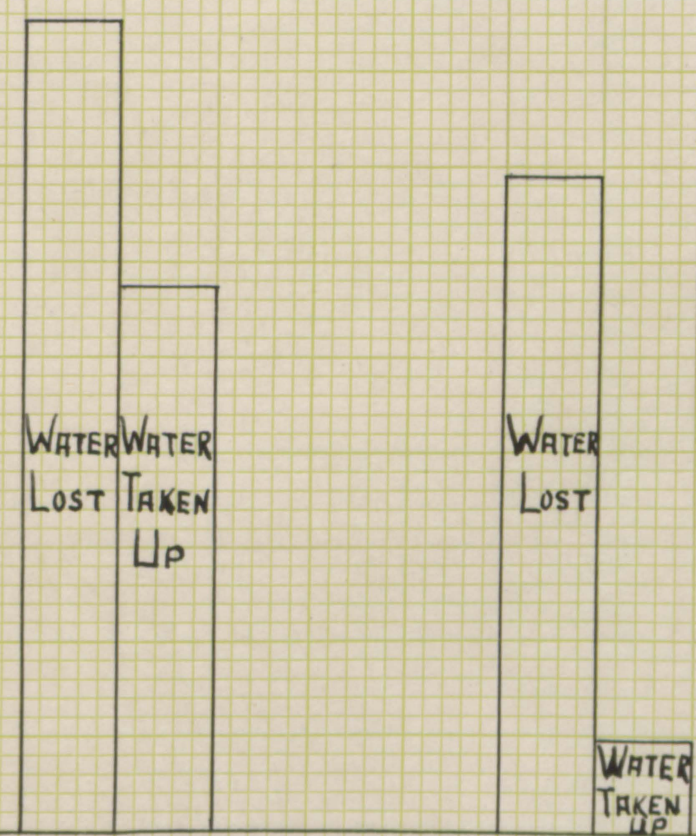

Two foot Columns. Four foot Columns. Six Foot Columns. EVRPORRTION LOSS COMPAREDWITH WATER-ThBLE LOSS. 
Table 9. - Evaporation from Free-Water-Surface.

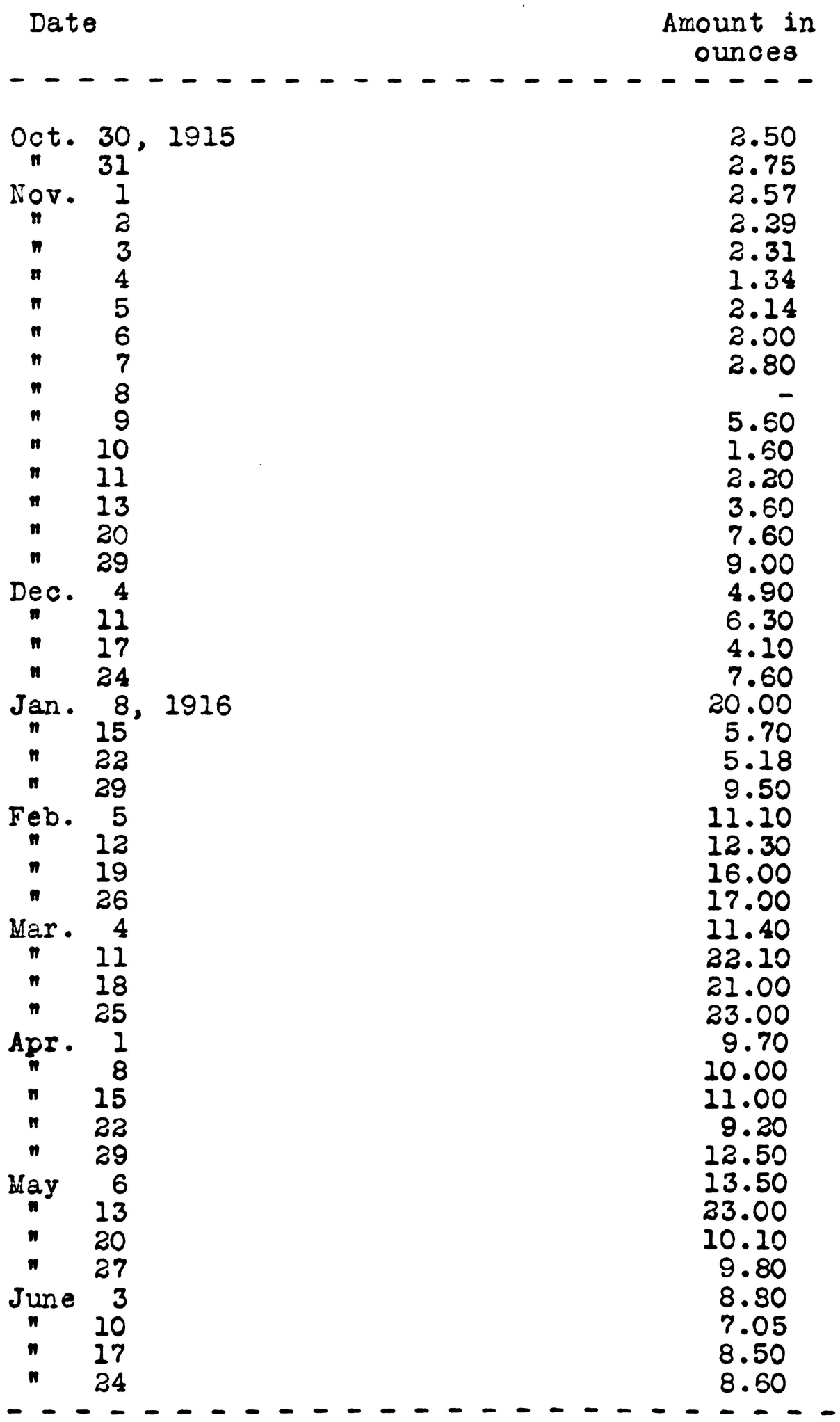

Total 289.33 

ation and Water-

300 Table Losses.

280

Evaporation Loss.

260

240

Water-Table Loss.

......... Evaporation Water-Free Surface.

220

200

$\int_{180}^{180}$

bo

$15 \mathrm{C}_{2}$

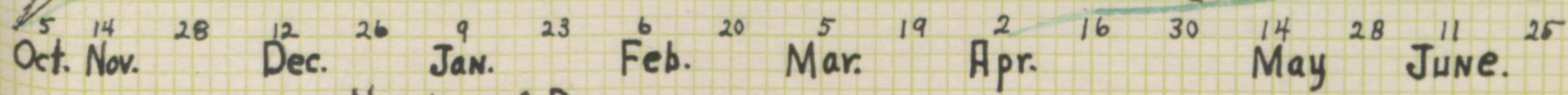
Number of Days 
General Observations -

The effect that the position of the water-table has upon capillary movement of water thru soils is otrikingly shown in Table 5. The rapidity with which evaporation is taking place as influenced by the force of capillarity is also plainly seen. It will be seen ther in examining Table 8 that practically the entire evaporation los from the 2-foot columns has been from the water-table. The average total loss in ounces for the 230 days from Series $A$, the 2-foot column, was 176.00; from Series B, the 4-foot columns, 56.90; and, from Series C, the 6-foot columns, only 9.88. It has taken a rarked quantity of water to maintain the water-level in $\mathrm{A}-\mathrm{I}$ and $A-2$. It has taken only about one-third as much to maintain the water-level in $B-1$ and $B-2$. While in $C-I$ and $C-2$, the quantity has been almost negligible.

In Series A, there was a constant and steady loss of soil moisture. The amount necessary, outside of the initial amount added on Ncvember 13th to reotore the proper level, varied from 1.98 ounces to 7.58 ounces for a 7-day period. At all the different observation periods $A-2$ was more moist on the surface than A-1. The different readings, as well as the total, showed that A-Z was losing the most water of this series. This was probably due to a sight difference in compaction of the soil when placed in the cylinders, a more perfect soil column for the movement of water having been made in the case of $\mathrm{A}-1$.

In Series B, a much lower evaporation 1083 occurred. The lossea for a period of seven days varied from zero to 4.34 ouncer. The initial amount added to $B-2$ on November 13 th is no 
doubt too high to be due entirely to capillary movement within the soil column. Probably the reason for this is partly due to the fact that soon after the commencement of the experiment, a crack occurred in the seam at the base of this cylinder where it was soldered onto the cylindrical tank. Before it could be repaired a few ouncea of water splashed out thru it during the different weighings, and a small amount must have evaporated. The major fortion of the evaporation loss from this series has been due to the capillary movement of water from the watertable, altho a large portion of the initial water in the soil colurn has been lost.

In exarining series $C$, it is notioed on the first day, November $13 \mathrm{th}$, that water was added to bring the water-levels up to the proper heighto, that 4.51 ounces was added to $\mathrm{C}-1$. This is accounted for by an error in resetting this column after the weighing had occurred. At the next reading when the cylinder was placed in its proper rosition, the water-level was above the mark on the eiphon winich was no doubt due to the amount adcied the previous reading. A new mark was made on the sicbon for $C-1$ which coincided with the water-level on November and was used thereafter. Not including this initial amount, the total loss for C-1 was 7.25 ounces and for $C-27.99$ ounces, which show that only a very olight movement due to carillarity, if any at all, was taking place in these columns; but that the frinciral loss has been due to the evaporation taking place from the upper fart of the soll column.

Table 6 gives the number of ounces of water lost from the soil columns thru evaporation. The durlicate readings of the different serios compare closely consiciering 
the number of factors that control or influence the water novewent. The total average loss for Series A was 176.92 ounces; for Series B, 85.25 ounces; and for Beries C, 68.56 ounces. Outaide of the first seven days, in which all the cylinders lost approximately the same amount, the cylinders of Series $A$ lost more steadily than those of $B$ and $C$, the average range being from two and ope-half cunces to six ounces for a 7-day period. Series B also, lost rather steadily, but the avcrage loss for a 7-day period is considerably lower than in the case of series $A$, the total average loss being practically one-half as much as in the 2 -foot column. In series $C$ the loss has taken place irregularly, varying from three ounces to zero.'. This is a striking difference from the more or less steady loss in the case of Siries $A$ and $B$. The total loss for Series C (68.56 ounces) was only 17.69 ounces less than in the case of series B. It will be noted, however, that the 1088 has occurred almost entirely from the soil colums.

Table 7 giving the $108 \mathrm{~s}$ by quarters shows that the greatest 103 was during the early part of the experiment when the upper parts of the columns were drying out most rapialy. After they had dried materially the loas decreased both becalise of the less water in the ourface layers and because this lessened water content decreased the rate of capiljary movement to the surface. The more favorable conditions during the latter part of the period have not been able to maintain the rate of loss from the soli columns.

Table 8 show a comparison of the amount of water lost by evacoration from the ourface and the amount absorbed from the water-table. It will be noted that in Series $A$ the anount of 
water absorbed by the soil column during the entire 220 days was only 0.92 of an ounce less than the amount lost by evaporation. Sc that as far as the total moisture content of the entire column is concerned it must contain practically the ame amount as it did at the beginning. In koth $B$ and $C$ series, however, considerably more had been loat by evaporation than had been taken up from the water-table, the difference being 28.35 ounces in Series B, and 58.67 ounces in Series C. In Series B the soil columns have taken up from the water-table tro-thirds as much as they lost, while in the $C$ series only about cne-seventh of the evacoration loss is equal to the water-table loss.

Table 9 gives the weekly evaroration in ounces from the free-water-surface.

\section{Discussion of Reglitg -}

These results indicate that depth of water-table has a marked effect on capillary rist of moisture in soils. Apparentiy when the water-table is very close to the surface, consideratle quantities of water move upward by cayillarity, but as its derth is increased the capillary rise becomes less. In this experinent capilary movement was in full oway where the water-table was but two feet deep, and it moved rather uniformly thruout the period of the experiment. In the 4-foot series the rate of carillary rise had decreaed greatly, the water-table loss being considerable less than the evaroration 10ss, altho, both were rore or less uniform in showing that capillarity was at work. The evaporation lcss being the greatest caused the soil column to looe moisture faster than it could be supplied 
from below by capillary action, which was also shown by its eurface which was harder and drier. This same condition of the surface wa noticed on the cylinders of serieg $C$, excert to a grester extent. In Series $C$ an almost neglifible quantity of water was taken up from the water-table, while the frincipal amount was lost thru evaporation from the upper soil layers, almost as much as in Series B. Consequently Series C contained much less water at least in the upper layers of soil than it did at the beginnine of the experiment.

The results show that depth of water-table is of frimary importance when discussing capillary rise of moisture in solis; and also, they tend to combat the old thocry which holds that capillary moisture can be brought rapidly to the ourface from consicerable dertho in the soil.

It is realized that in thio single experiment only one kind of soil is under study, a soil of uniform texture thruout its whole depth - a condition which would rarely be found under actual field conditions. Then too, the soil was tamped in the cylinaers which again is but an approximation of the natural soid in aitu. However, the results indicate that depth of watertable must be the prime factor in determining the capillary rise of moisture to the surface, which goes to prove that groundwater is not lost thru capillarity when it otends at a consicierable distance below the surface.

It seems probable that in a given soil, capiliarity vill carry water only to a given height, beyord which height, all loss of moisture occurs in the form of water vafor caused by evaroration into the air circulating in the interotitial efaces thruout the soil mass. 
Also, that in the field where the water is at a considerable depth below the surface, the lose of moisture thru evaporation occure largely from the surface foot of soil, and that kelow this depth very littie is lost by evacoration. tindoubtediy the per cent of moisture in the soil is a very important factor, capillary movement decreasing with decreasine noisture content. Where the eurface foot $c r$ two of soil is very moiat capillarity may for a time act in carrying a considerable anount of this water to the eurface. 


\section{Experiment II. \\ Loss of Tater thru Capiliarity \\ with and against gravity.}

Gravity and its effect in removing the free moisture from the soil is recognized and its constant pulling force in removing minute amounts of water lcng after the excess has been drained away has often been observed. However, the fact that it may control most of the soil moisture, after it has passed the upper twelve to eighteen inches of soll has not received much attertion.

Rotmistrov has come out very strongly against the idea of the power of cacillarity in removing the soil moisture from the lower layers of the soil in his work on the Mirculation of Tater", as well as in his later work on "The Nature of Irought! He* states that, "there is a constent and steady movement of water downwards, not only in the deep soll layers which cannot be dried, but in the upper layers as well." AB the result of several experiments, he**holds that the downard movement not only takes place from derths of 95 to 105 centimeters (38 to 42 inches), but from the small depth of 35 to 45 centineters ( 14 to 18 irches), and states that the speed with which the water moves is from 15 to 20 centimeters (6 to 8 inches) per month on old ploughed fields, but more glowly on unploughed soil. In concluding he*** states that "water percolating to a depth of 40 to 50 centimeters (16 to 20 inches)

* Nature of Drought, p. 20.

* Circulation of Fater, pp. 30 and 81 .

** Nature of Drought, $p$. 20 . 
does not return to the surface except by the way of rocta; all the water not seized by the roots goes down into the deep layers, moving at the rate of about 7 feet yearly."

It was largely becalise of Rotmistrov's results that this experiment was planned and undertaken, the object being to determine, if possible, how inportant gravity was in controlling soil moisture under well defined conditions.

Plan of Experiment -

The general plan adopted was to take two columns of soil, containing a maximum amount of capillary moigture, and allow one to dry out with the aid of gravity and the other in the usual way against gravity.

Accordingly, two galvanized iron cylinders were constructed, six feet in length and six inches in diameter with one end of each can closed air tight. Foprty-four one-inch holes were cut in each of the cylinders, being arranged in eleven horizontal series of fours, six inches apart. An iron band with a one-fourth inch lip was made to slip down over the top of the cylinders, and wa bolted to the inverted oylinder to prevent the soil from dropping out. In the case of the erect cylincer it was used only to keep the exposed surface area equal for both cans. Two-inch adhesive tape was used to cover the holes, this being wrapped horizontally around the cylinders covering each series of four holes as a separate unit. The tape was covied with a heavy coating of parafin to insure no 1088 of rolsture thru the holes.

The moibture samples were taken from each vertical row of holes at monthly intervals to determine the movement of 
moisture upwards or downwards. A fine sandy loam soil wa lised, and a regular, ohort handie, one-irch soil augur was used in removire the samples.

Exrerimental Metrods -

The fine sandy loam soil used was obteined from a creek bottom. It was sifted and placed in the greenhouse in a pile to reach a uniform moisture content. When the mointure became uniform thruout the pile, three samples were teken and the moisture contert determined. They were dried in an electric cver for 8 hours at a temperature from 105 to 110 degrees centigrade. The per cent of moisture in the amples, variea from 16.09 to 16.88 - average 16.59 .

To find the cptimum moisture content of this soid several samples were taken and different amounts of water added to each successive sample, increasing or decreasing the amount of water, until the optimum conter.t was obtained. The water content finally selected was 27.08 yer cent. A sufficient amount of soil was then weithed to fill both cylinders and opread out in a four-inch layer on a large table. The necessary amount of diatilled water was added to bring the entire mass up to the optimum content. The soil was covered with an oil cloth and allowed to stard ten days to insure uniform digtribution of the water. In the meantime the soil was mixed and turned several times to ald in the distribution.

On February 12, 1916, three samples of the soil were taken from different farts of the mass and their moisture content determined. The moiature percentages obtained were 22.97, 23.07, and 22.91 - averąe 22.98. Both cylinderowere 
filled with the soil at this moisture content by the same nethod as used in Experiment $I$, page 32, the tamp used and the process of compaction being the same.

After the cylinders were filled they were placed in a small room where the atmospheric conditions were practically uniform. One cylinder was set on the floor in an erect position, the upper end beirg open; the other, was hung in an inverted position from an iron pipe which crossed the upper part of the room, the lower end being open. The open ends of the cylinders came within one foot of each other, and no draughts or rapid temperature changes were allowed to effect them. During the first month temperature and water evacoration records were made at the respective levels of the open ends of the two cyinders, which showed no appreciable differences, thus showing that conditions for evacoration were the same for each.

In sampling the cylinaer were laid on a long table (a great deal of care was used in the handling of the cylinders to prevent rupture of the soil columns) and after the removal of the ample which was taken to a derth of two to three inches, the hole was filled with melted parafin. As soon as paraffin hardened, the tape was placed back over the hole and another thin coating of paraffin was applied. Care was taken to weigh the samples immediately after they were removed from the cylinder. After all the samples had been taken and weighed, they were placed in an electric oven and dried for six hours at a tenperature of 105 to 110 degrees centigrade. Cylinders were returned to there original position after each ompling. 800 after the experiment started the soil in the erect 
cylinder seem to shrink away from the sides, leaving a slight crack between the soil column and the cylinder wall. Also, the surface soil in both cylinders shrunk away from the lip that overlapped the surface. These openings were filled with paraffin as often a.s required.

$$
\text { After the last set of samples were taken a sample }
$$
two and one-half inches deep was taken from the ourface layer of each cylinder.

Experimental data-

The following pages contain tables of results obtained. 
Table 10. Evaroration loso, With and Againgt Gravity.

(Per cent Moisture in the Soil)

- Measurerent from open erd.

** Estimated. Time No. Depth*
$\begin{aligned} & \text { of } \\ & \text { Sam- increa content moist. moisture content moist. moisture } \\ & \text { ple }\end{aligned}$

Yarch 11

$\begin{array}{rr}1 & 6 \\ 2 & 12 \\ 3 & 18 \\ 4 & 24 \\ 5 & 30 \\ 6 & 36 \\ 7 & 42 \\ 8 & 48 \\ 9 & 54 \\ 10 & 60 \\ 11 & 66\end{array}$

18.09
10.11
10.46
20.24
20.30
20.88
20.81
$21.00 * *$
21.31
24.12
24.57

$\begin{array}{rr}4.89 & 4.89 \\ 3.87 & 3.87 \\ 3.52 & 3.52 \\ 2.74 & 2.74 \\ 2.68 & 2.68 \\ 2.10 & 2.10 \\ 2.17 & 2.17 \\ 1.98 & 1.98 \\ 1.67 & 1.67 \\ +1.14 & 1.14 \\ +1.59 & 1.59\end{array}$

19.78
20.85
19.88
21.56
19.80
21.38
20.42
21.42
20.17
21.4 .6
20.24

$\begin{array}{ll}3.20 & 3.20 \\ 2.13 & 2.13 \\ 3.10 & 3.10 \\ 1.42 & 1.42 \\ 3.18 & 3.18 \\ 1.60 & 1.60 \\ 2.56 & 2.56 \\ 1.56 & 1.56 \\ 2.81 & 2.81 \\ 1.52 & 1.52 \\ 2.74 & 2.74\end{array}$

Apriz

$\begin{array}{rr}1 & 6 \\ 2 & 12 \\ 3 & 18 \\ 4 & 24 \\ 5 & 30 \\ 6 & 36 \\ 7 & 42 \\ 8 & 48 \\ 9 & 54 \\ 10 & 60 \\ 11 & 66\end{array}$

$6 \quad 17.65$

0.4 .4

5.33

17.74

1.07

5.24

1.00

4.53

18.58

1.66

19.01

1.29

4.40

3.97

19.44

19.66

1.44

3.54

1.15

3.32

21.11

20.72

21.79

$+0.11$

1.87

0.59

2.26

2.33

1.19

22.14

2.33

0.74

16.81

2.97

6.17

19.38

19.05

19.65

19.17

19.88

19.81

19.73

19.52

19.75

19.42

1.47

0.83

1.91

0.63

3.60

3.93

1.50

3.33

0.61

3.81

Lay 6

1616.53

1.12

6.45

0.83

6.07

17.98

0.48

5.00

0.43

4.73

0.64

4.61

0.60

4.14

0.71

4.03

1.35

3.22

19.76

1.08

3.35

20.43

1.36

2.55

1.09

18.96

19.53

18.98

18.90

19.50

19.70

19.15

10.71

19.34

19.46

1.69

3.10

3.17

0.65

3.25

1.71

3.46

0.82

3.23

21.05

June 3

11

66

$\begin{array}{rrrrr}1 & 6 & 14.96 & 1.57 & 8.02 \\ 2 & 12 & 15.39 & 1.52 & 7.59 \\ 3 & 18 & 16.42 & 1.56 & 6.56 \\ 4 & 24 & 16.00 & 1.25 & 6.08 \\ 5 & 30 & 17.68 & 0.69 & 5.30 \\ 6 & 36 & 17.56 & 1.28 & 5.42 \\ 7 & 42 & 18.51 & 0.44 & 4.47 \\ 8 & 48 & 18.44 & 1.32 & 4.54 \\ 9 & 54 & 19.11 & 0.52 & 3.87 \\ 10 & 60 & 19.36 & 1.07 & 3.62 \\ 11 & 66 & 19.69 & 1.36 & 3.18\end{array}$

18.67

$+2.15$

4.02

$+0.15$

3.45

0.07

4.00

0.75

4.08

0.33

3.48

0.18

3.28

0.66

3.83

0.02

3.27

0.18

3.64

0.29

3.52

0.75

4.31

15.32

3.68

7.70

18.86

0.67

4.12

16.33

2.65

6.65

16.62

2.28

6.36

18.41

1.09

4.57

19.05

0.65

20.58

$+1.43$

3.93

19.19

0.52

2.40

19.31

0.03

3.79

18.84

0.62

3.67

18.55

0.12

4.14

4.43 


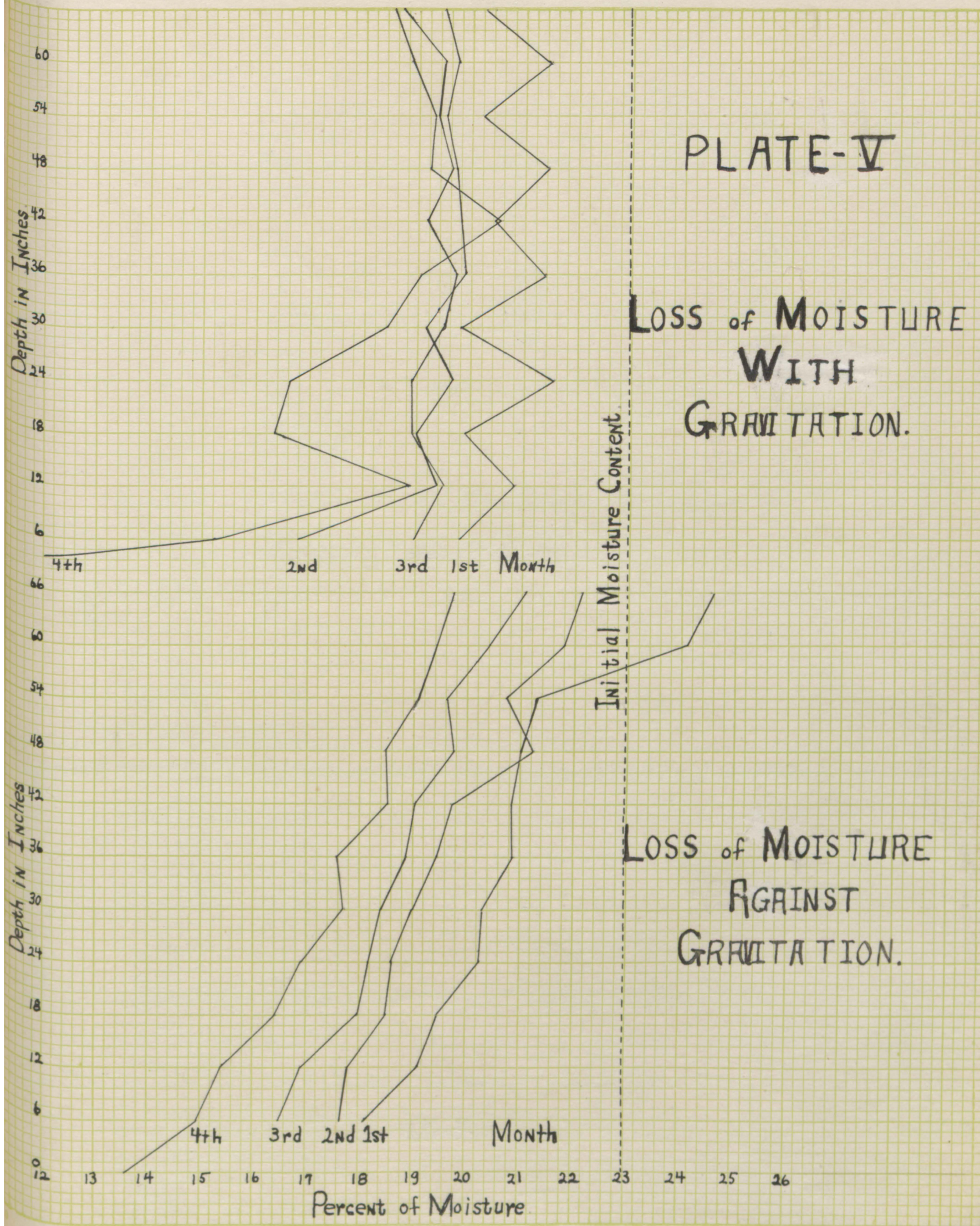


Table 11.- - Summary of Table 10 .

(Per cent Moisture in the Soil)

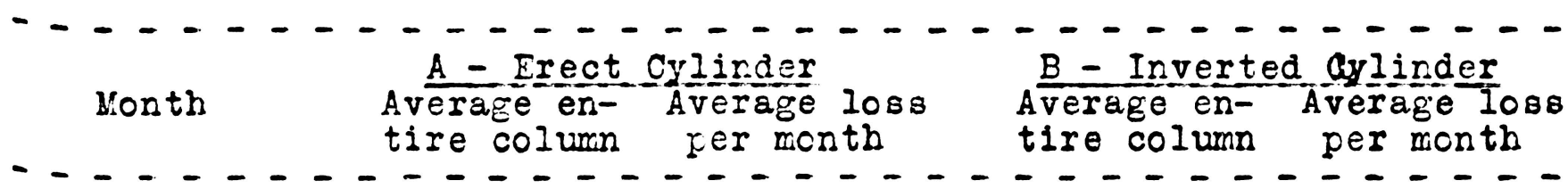

Initial content

22.98

22.98

First

Second

Third

20.90

19.66

18.78

Fourth

17.64

2.08

1.24

0.88

1.14

20.63

19.29

19.28

18.28

2.35

1.34

0.01

1.00

General Observations and Discussion of Results -

The results as shown in Table 10 and graphically

illustrated on Plate $V$, page 59, makes clear a difference in the factors controlling the evaporation from cylinders under the conditions. It will be noted that in the four different sets of samples taken from the erect cylinder that the moisture content increased gradually frow the open end of the oylinder to the closed end, except for samples No. 9 (probably due to excess in sample No. 8) on April 8th, and May 6th, and samples Nos. 6 and 8 on June $3 d$ which were slightly less than the samples immediately above them. These were the only samrles that interrupted the gradual increasing moisture content running from the open to the closed end of the cylinder. In the inverted cylinder an entirely different situation was in evidence. The aid of gravity was evident as is cleary shown by the chart. During the first month all the rescetive six-inch soil layers of the erect cylinder lost molsture except layers represented by 
samples NOB. 10 and 11 which were at the bottcm of the cylinder. These increased $1.14 \%$ and $1.59 \%$ respectively over the initial moisture contert. No doubt there was a movement of moisture downward into these layers from the ones immediately above, which is roemphasized by the fact that samgle No. 11 contained almost one-half per cent more moisture than sample No. 10. The layers of soil represented by samples Nos. I to 9, inclusive, lost moisture with decresaing amounta commencing at the aurface. The per cent of moisture varied from $18.09 \%$ to $24.57 \%$, a range of $6.48 \%$.

During the gecond month all layers lost moisture except the layer represented by sample No. 8, which gained $0.11 \%$. Except for this sample the moisture gradient was gradual from top to bottom of column, the lowest moisture content being at the top and gradually increasing until the highest was resched at the bottom. The per cent of moisture varied from $17.65 \%$ to $22.14 \%$, a range of $4.49 \%$. The greatert 1038 was not at the top as in the case of the first month's result3, but at the bottom of the column in the layers which gained during the first month.

During the third month, all layers lost moisture without exception. The molature gradient was gradual, increasing from top to bottom with the exception of sample No. 9 which was $0.13 \%$ less than sample No. 8. The reason for this may be explained by the fact that omple No. 8 contained a olight excess of molsture at the previous sampling, and due to the same cause it still contained an excess amount in comparison to the layer immediately below. The per cent of moisture varied from $16.53 \%$ to $21.05 \%$, a range of $4.5 \%$ which was practically equal to the 
previous month. The greatest losses occurred in the surface layer and the four bottom layers, or in thoae layers which lost the lesot the previous month.

During the fourth month, all layers lost moisture without exception. The moisture gradient was gradual, increasing from top to bottom, excepting samplea Nos. 6 and 8 which contained a lesser per cent of moisture than the layera immediately above them by $0.13 \%$ and $0.07 \%$ respectively. The per cent of molsture varied from $14.95 \%$ to $19.69 \%$, a range of $4.73 \%$, slightIy more than the previous two months, due probably to the increased room temperature. The loas from the different layers bore no particular relation to the 1088 of the previous month, the greatest loss occurring in the surface three layers.

In examining the loss of moisture from the inverted cylinder something unusual is noted in the first month's results. There was a 1088 from every layer, but the 108808 was not like those from the erect cylinder. The moiature by layers incressed and decreased successively from the open to the clooed end. The average total 1088 of molsture thruout the column was $0.27 \%$ more than in the case of the first month's results of the erect cylinder. The per cent of moisture varied from $19.78 \%$ to $21.46 \%$, a range of $1.68 \%$. The molsture remaining in the column is more evenly distributed thruout the column than in erect cylinder which is evidence of the effeot of gravity. During the second month, similar results to the first month were obtained, all layers looing moisture, the largest amount being from the layer next to the open end. The moisture content of the various samples commencing at the open end varied succesaively up and down until sample No. 6 was reached, after 
which there was a regular decrease until sample No. 8 was reached, at which point tine former procedure was reatored. The total 1039 was $0.10 \%$ greater than the loas from the erect cylinder. The per cent of ioss varied from $16.81 \%$ to $19.83 \%$, a range of $3.07 \%$ which is conoiderably larger than the range of the first month.

The moisture conditions at the end of the third month period were somewhat irregular. Samples No8. 1, 2 , and 5, showed an increase in those respective layers; the rest lost in varying amounts. The total loas was almost negligible, while the per cent of 1038 varied from $18.86 \%$ to $19.71 \%$, a range of only $0.75 \%$.

During the fourth month moisture was lost thruout the entire column, except in the layer represented by sample No. 7 which showed an incresse of $1.43 \%$. The total $108 \mathrm{~s}$ was greater than the previous month by almost $1.00 \%$, but less than the $108 \mathrm{~s}$ from the erect cylinder, the difference being $0.14 \%$. The per cent of moistur 2 varied from $15.32 \%$ in the surface to $20.58 \%$ in sample No. 7, a range of $5.26 \%$. As was was noted in the third month's results, there seems to be an accumulation of moisture occurring within the column, either due to gravity or some other force. This month the accumulation seems to be at the place revresented by sample No. 7 . The greatest 108 ocourred in those layers which contained a ourplus the previous month or which lost very little.

Inasmuch as this was the end of the experiment samples of soil were taken from the surface two and one-half inches of each column, along with the fourth month's samples, and their moisture content determined. There was $13.53 \%$ in 
the sample from the erect cylinder, and $7.08 \%$ in the case of the sample of the inverted cylinder, a difference of $6.50 \%$. In comparing these percentages to those at a distance six inches from the surface, there is no marked difference in the inverted cylinder. The surface of the inverted cylinder containing only $7.08 \%$ is practically air dry, while three and onehalf inches further up a moisture content of $15.32 \%$ is present. In taking the sample from the inverted cylinder a great deal of difficulty was experienced. The soil seem ed to be very compact, hard, and dry. This compaction or settling of the soil must have begun soon after the experiment started and continued thruout. Such a condition would hinder somewhat the loss of moisture as resulting from diffusion, as well as alter tine 1033 by capillarity working with gravity.

The following point of note are observed from these reaults: (1) In the case of the erect cylinder where the 1038 of moisture by evaporation is either thru diffusion or partly by the suppose-force of capillarity, tine gresteat difference between the moisture content of any two layers, is found to be between six and twelve inches bolow the surface (as is the cses in the first month's results), or between twelve and eighteen inches (as is the case in the other three montho). This would indicate that the greatest loss of molsture is occurring in the surface eighteen inches. (2) The total 1088 of moisture from the reapective layers of the erect cylinder varied almost directly with the height, the greateat being at the top and the least at the bottom. It would seem that if capillarity was the important means by which moisture escaved from the soil, 
that there should be a more constant loss thuout the different layers of the entire soll column. However, as this isn't the condition it would indicate that the loss by diffusion is the more important.

(3) Diffusion and capillarity being two forces which supposedly will act equally well in either direction will not explain the resulta obtained from the inverted cylinder. Gravity is at work as is plainly seen in the first two month's results. Soon after the experiment was started tine moisture must have begun moving downwards, evidently with a speed of about six inchea plus per month (see Rotmistror conclusions page 54). This regular movement decreased as the moisture content became lower which produced the irregularity of the results during the third and fourth months, and caused increased amounts of moisture over the previous month to occur at different places along the column (note samples Nos. 1, 2 , and 5, of May 6th, and No. 7 of June 3d). (4) If capillarity is an important force in the 1083 of 8011 moisture, it would seem that a greater loss should have occurrod from the inverted cylinder during the last tio months. (5) A comparison of the range between the maximum and minimum moisture contents for the different montha gives further proof of the effect of gravity. In the case of the erect cylinder, a range of $6.48 \%$ occurred during the first month, due to the rapid drying out of the surface layer and the accumulation of an excess at the foot of the colluin. The second month the range, 4.19\%, was considerable less, almost $2.00 \%$. The third and fourth montho showed a small increase, $0.03 \%$ and $0.21 \%$ respectively, orer the previous month. In the case of the inverted cylinder the situation is 
entirely different. The range by months being 1.68\%, 3.07\%, $0.75 \%, 5.23 \%$ rescectively for the first, second, third, and fourti months. Why the maximum range occurred during the last monti $r$ ther than the first month as in the case of the erect cylinder, was probsbly due to the effect of gravity. (b) The total 1088 of moisture from the inverted cylinder was greatex during the first two montho than from the erect cylinder. Inasmuch as there was a higher per cent of moisture within the column during this time, the force of gravity wa more noticeable. The loss during the last two montho was less and was probably due to the decreasing effect of gravity upon the movement of the film moisture within the soil, as well as to the compaction and settling of the soil in this cylinder. 


\section{FIELD EXPERIMENTS.}

\section{Experiment III.}

i study of the absorption, run-off, and
loss of moisture under field condtions.

In the experiment described below the moisture problem is studied under the conditions of the field. The plan was to determine not only the per cent of the raifall penetrating the soil, but what becomes of the water which enters. Further it proposed to find the exact effect of the water running off the surface upon the soll itself.

It is realized that the area of land subjected to atudy is small and that the results apply to but one type of 80i1. However, the important forces thet control the movement of moisture must be the same everywhere, therefore, the character of the resulta obtained will be applicable to a greater or lesser extent to other types of soil.

\section{Plan of Experiment -}

\section{(Description of Plots)}

Four plots, 91 feet in length and $51 / 2$ feet in width were carefully laid out on the eastern slope of a hill whose inclination was about $41 / 2$ degrees. The upper end of the plots commenced just at the brow of the hill and extended down the hill to its base or to the point where the slope ceased. Two plots, $A-1$ and $B-1$, were enclosed within a 6-inch board wall. The boards used were ordinary white pine boards, and were 16 feet 
in length and 6 inches in width. They were entrenced 4 inches and allowed to extend 2 inches above the surface of the ground. In order to have boards remain securely in position strong stakes, 18 inches in length and 2 inches in widh, were driven in the ground at the ends and in the midale of each board, to which the boards were mailed. After the boards were entrenched, the soil removed was placed back in the trench and tamped, so as to prevent excess washing next to the boards.

At the lower end of the plots concrete platforms, triangular in shace, were built with a slight slope. The urper sides were left flugh with the surface of the ground while the other sides were built with an eight-inch concrete wall. At the lower foints of the platforms, four-inch galvanized iron pipes, 9 feet in length, were placed in the concrete and cemented to the platforms. The pipes extended to galvanized iron tanko sunk in the ground and provided with covers.

The tanks were used to catch the run-off and eroaion. These tanks were placed in the ground, 9 feet from the platforms, and were buried deep enuf so as to allow the proper drop ( 3 inches) for the pipes which led from the platforms and entered the tanks thru four-inch holes located just beneath the rim of the tanks. The pipes were securely fastened and soldered to the tanks so as to prevent any water $108 s$ by excesaive run-off. The tanks were drained by inch and one-half iron pipes connected to the bottom of the tank and extending underground to a small roadside ditch 12 feet away. On the outlets of the pipes fauceta were placed. Within the tanks, where the rater entered the drain, a 1-inch iron pipe one inch in length, was fitted 80 as to sorew into the drain. This device was used in separating the soll 
Diagatam of Field Plots

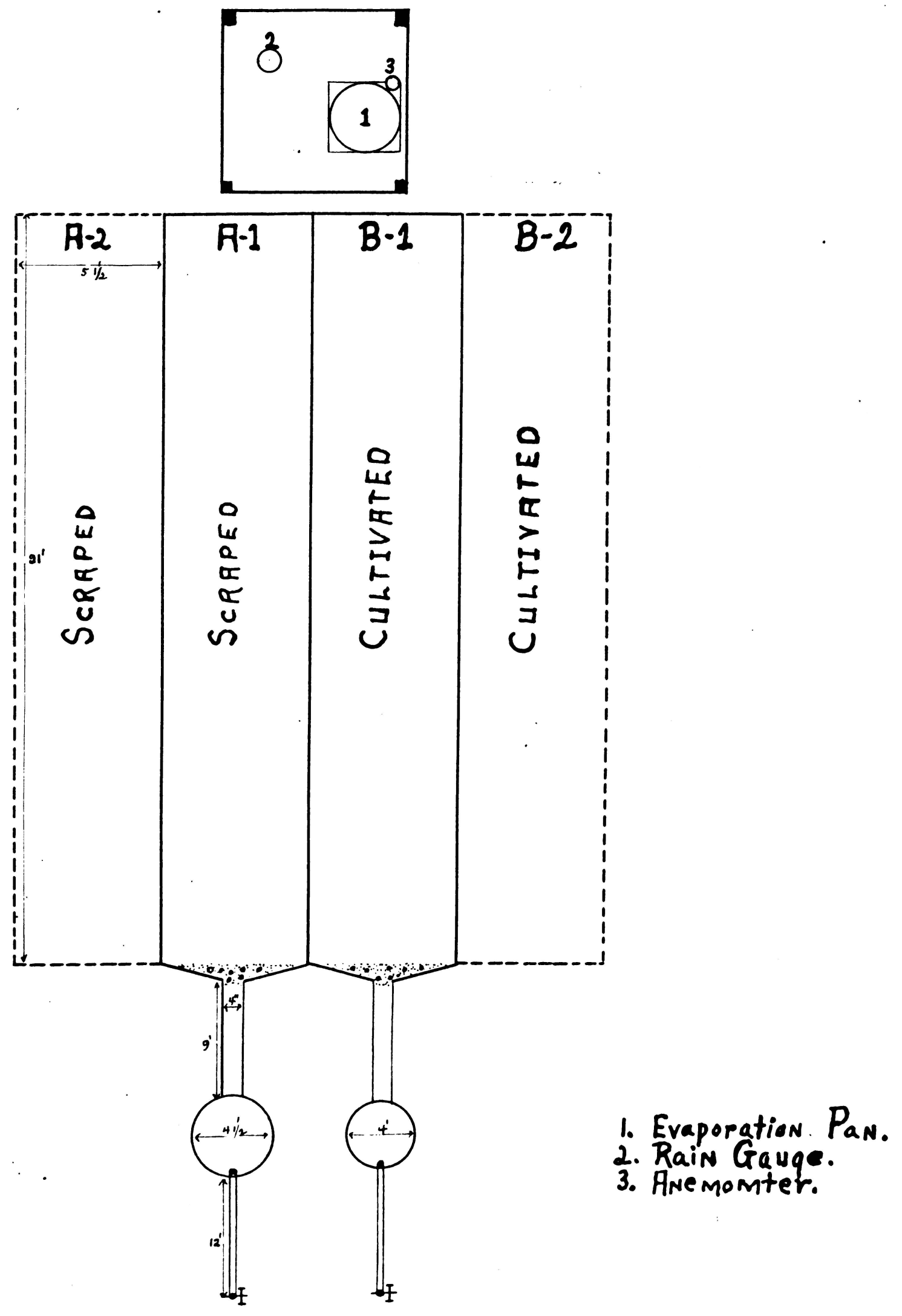


from the water. A rubber stopper was placed in the upper end of the short pipe. The covers of the tanks were fastened down by hooks.

Plots $A-2$ and $B-2$ were not enclosed, but were treated in every way the same as plots $A-1$ and $B-1$. These outside unenclosed plots were used for determining the moisture in the soil during the season since it was not considered wise to penetrate the enclosed plota with the sampler.

Lysimeter Construction

Two lysimeters, $16 \times 18$ inches in area $(0.004,59$ acre) were constructed near the lower end of the drainage plots. A plot of ground $6 \times 61 / 2$ feet was laid out, and all the soil within this plot down to a depth of $41 / 2$ feet was removed, except two columns of soil $18 \times 20$ inches. These two columns were carefully pared down until they were exactly $16 \times 18$ inches square. A long bladed corn knife was found very useful in paring the columns. Square board encasements, $22 \times 24$ inches, were flaced around each column which permitted a space of 3 inches to exist entirely around the soil columns. This space was filled with concrete. The concrete was re-enforced perpendicularly on each side, at the cornere, and horizontally at four different levels with No. 9 galvanized iron wire. Square galvanized iron bands, four inches in width, and just the size of the soil columns were embedied in the concrete at the top and allowed to extend two inches above columns of soil. After the concrete had set, the columns were laid over on their sides and a concrete bottom, 4 inches thick, was placed in them. In the center of the bottoms, an inch iron pipe, 6 inches in length, was embedded 
in the concrete. This pipe extended one inch below the bottoms and served as an outlet for the percolating water. In order to prevent the soil from entering the pipe, a small pack of glass wool was placed at the upper end of the pipe. Columns were raised and placed on an 8-inch foundation. After the board encisemento were removed, the column were painted twice with a rich mixture of cement and then covered with a coat of coal tar. The lyoimeters were thereby made water tight.

The dirt removed was returned to the pit and carefully tamped around the column, excepting on the south side where the pit was unfilled to give access to the bottoms. The percolation water was caught in a two quart jar, closed with a rubier stopper and connected to the outlet in the bottom of the columna with properly bent glass tubing.

Veather Apparatus

Weather appratus was stitioned at the end of these plots, consisting of a rain-gauge, an evaporation pan and measuring device, and an anemometer. These were enclosed within a 4 foot wire fence. Observations were made daily at 7:15 am. The Soil

The soll is classified as a "Silty Phase of the Shelby Loam! It consists of a fine sandy or silty loam of a gray or brown color from 7 to 8 inches deep, grading into a redaiob-yellow sandy clay, which extends to a depth of 3 feet or more. The type is of glacial origin and belongs to the Glacial \& Loessial Province. It has be $n$ in wheat continually for the past 15 years. After the wheat was harvested during the forepart of July, 1915, the ground was immediately plowed, disked, and sowed to compea, these being turned under in the fall 
PLATE-VIII.

\section{DIAGRAM OF LYSIMETERS}
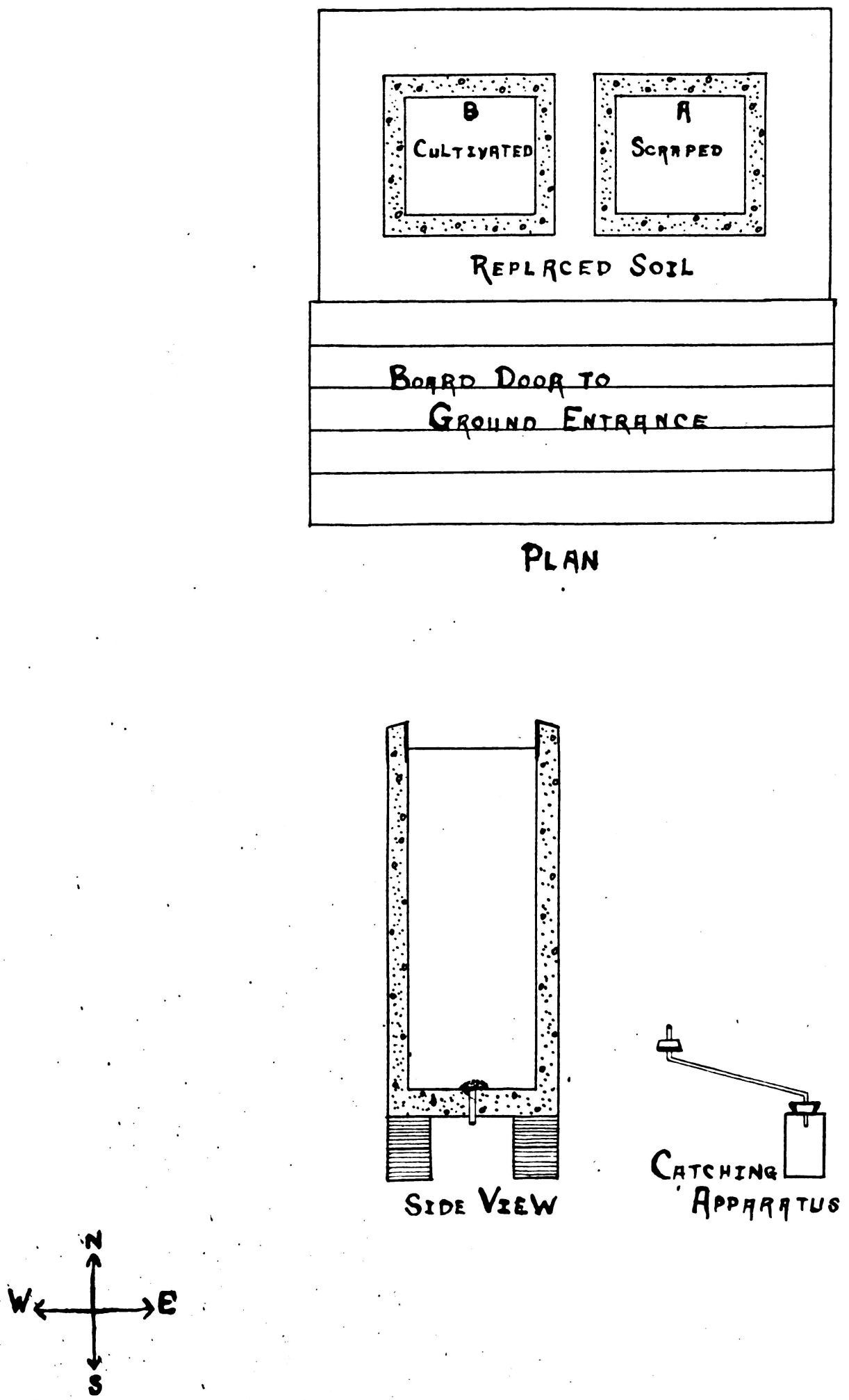
just previous to the drilling of the wheat.

(Measuring Tater Run-off and Soil Eroaion)

Imrnediately after each rain the amount of water that ran off the enciosed plots wa measured. This was done by a rule graduated in inches and tentha, measuring down to the top of the one-inch pipe. After the depth of water was determined, ten to fotity grams of Calcium oxide was added (depending upon amount of water in tank) to flocculate the soil particles and to clarify the water. After several houra (5 to 10) the rubber cork in the upper end of the iron pipe was rernoved, faucet to the outlet opened, and the tanks were allowed to drain. When Nater had drained away down to the top of the one-inch pipe, ten-gallon cans, weighed, were claced under the drain outlet, the one-inch pipe unscrewed, and the remaining muddy water and sediment was allowed to drain out. After drainage ceased and the $\operatorname{tank}$ were cleaned, the cans were removed, weighed, and allowed to stand for a few hours, after which all excess water was drained from the cans by siphon and cans reweighed. The wet soil remaining in the bottom was then thoroly mixed and two samples of approximately 200 grams were taken. Their moiature content was deternined and the average of the two was used in calculating the total water in the mixture and the amount of eroded soil (oven dry). The amount of water draining from the tanks, plus the amount removed by siphoning, plus the amount in the wet soil, equals the total run-off.

Soil Sampling

Soil samples were taken regulariy twice a week and after each rain of importance in plots $A-2$ and $B-2$. The sampling was done with a King sampler and samoles were taken every 
foot to a depth of four feet. The ordinary olip cap, seamless tin, soil cans were used. Three sets of samples of four each were taken in each of the two outside plots at intervals of thirty feet, commencing near the upper end of the plots and working down. After samples were taken the holes were refilled with loose soll and tamped. Short stakes were placed in the holes to indicate the place of sampling. The following set of samples taken on the next date of sampling were taken twenty-two inches frox the last set. This method was oontinued across the plot, until four holea had been made, and then the process was repeated twenty-four inches lower down the hill from the previous row of holes. This plan was followed thruout the experiment.

The samples were taken to the laboratory and weighed. Covers wer: removed and they were placed in an electric oven and dried for ten hours at an approximate temperature of 105 degrees centimade. They were then removed, cooled, reweighed, and their moisture content determined. A torsion balance accurate to one-tenth of a gram vas used during the fore part of the experiment, later it wa found that thia point of accuracy was unnecessary and a torsion balance, accurate to one-half gram was used.

Determination of Thater-Holding Capacity of Field Soll The soil samples taken on July 8 th were used in determining the water-holding caracity of the field soil. After the moisture content was determined, the amples were pulverized in an iron mortar, and rassed thru a 20-mesh sieve. The fine portion of the tinree different samples of each plot which represented the first-foot section were thoory mixed together and 
placed in a bottle with air-tight stopper. The same was done for the other respective foot-sections. The W.H.C. of these mixtures was determined in duplicate by the Hilgard method*. Small cylinders, one centimeter in depth and 4.84 centimeters in width with perforated bottoms were used. They were filled with the dry soil, allowed to drop fifteen times from a height of one-half inch, weighed, placed in a shallow pan containing water one centimeter in depth until fully saturated, removed, allowed to drain ten seconds, wiped dry outside of cylinder, and reweighed. The difference in the two weighings represented the amount of water absorbed. The calculations were made on an oven dry basis. From the W.H.C. figures, the wilting coefficient was calculatediyformula given by Briggs and Shantz**, viz:

Wiltin Coeff. $=\frac{\text { W. H. C. (Hilgard method) }-21}{2.9}(\operatorname{error} 8.3 \%)$

Table 12. - Water-Holding Capacity

and Wilting Point of Field soil.

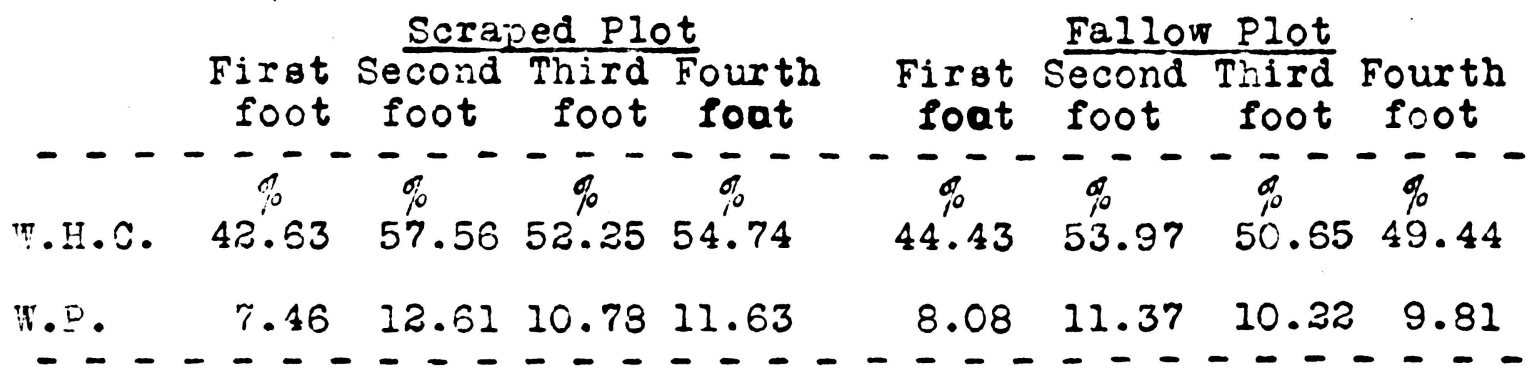

* Soils, p. 209.

* U.S.D.A., Bur. of Plant Industry, Bul. 230, 1912. 


\section{Exserimental Methods -}

During the winter of 1915, wheat grew upon the four plots, but just as early as possible in the spring of 1916, the plots were scraped, the wheat plants removed, and the surface of the soil placed in a smooth, bare condition. By April 15th, the construction work was completed and the experiment was ready to start, except for the lysimeters.

In order to see how closely the two enclosed plots were going to check both were left bare until April 26th (see Tables 13 and 14 for results). On this date, plots B-I and B-2 were graded to a depth of 6 inches. The surface was more or less srocthed with a rake and left in this condition.

On liay loth the lysineters were completed and ready for oferation. The surface of $B$ was placed in the same condition as the E plots. A was screped as in the case of the A fiots. Thruout the experiment the rescective lysineters received the identical treatment as the plots.

Iuring the fore part of the experinient wecds started ercwing here and there upon the bare flots. As soon as they becare ncticeable, the plots were gone over with a sharp hoe, care beirg used not to locsen any more soil than necessary. On liay 17 th and 3lat when the plots were scrared the locoened soil Was not renoved (see Table 13 for effects lipon ancunt of erosicn in rains of Nay 28 th and June $2 d$ ), but thereafter they were ewert off by the use of a brocm and all loosened soil removed. As ofter as necessery fioto $\bar{B}-1$ and $B-2$, as well as lysineter $B$, were cuitivated, thus destroying all weeds and at the seme time kecring the soil in good tilth. 
On June 6th and August 8 th considerable soil had collected on the platformo of the enclosed plota. This was removed, weighed, and moisture content determined, from which the amount of air ory soil calculated. This was added to the erosion column as may be noted in Tables 13 and 14.

In taking the ample of the 3 d foot in plot $B-2$ on Iune 28 th, the soil eampler was kroken and it was impossikle to take samples of the third and fourth $f \in e t$, se well as samples from other plot for this day. Samples of the first and second feet at the upper end of plots were taken on June 29 th from plot A-2 with another augur. Due to indications of rain on July lot samples were also taken from the first and second feet at the upper end of both plots. On July $3 d$ the sampling was continued as usual and no further trouble of this character was encountered.

In determining the pounds of water lost from the plots and lysimeters, 95.6* younds wies used as the average weight per cubic foot of the top four feet of soil. Inasnuch as the area of the plots was 500 square feet, this layer conteined 191,200 pounds of soil. The lysimeters contained 764.8 founds each. Also, 5.2 pounds was used as the weight of an inch of water covering an area one foot aquare.

* "Soils, their properties and Vanagement", Lyon, Fipfin, and Buckman, p. 117. 
Table I3. - Iffects of Rainfall upon Scraped Flot.

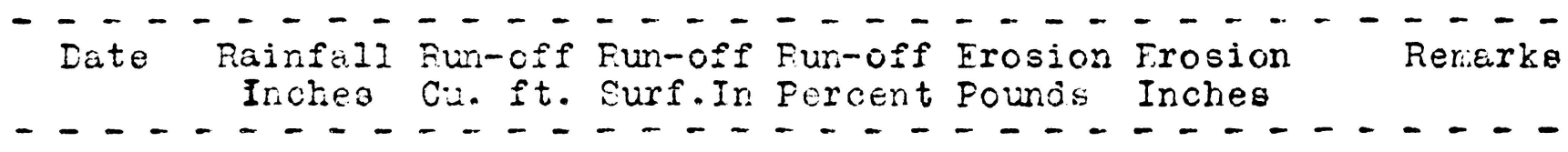

1826

Ayr. 15

16

$17-29$

0.30

.I 0.01

$26 \quad 0.08$

26

iray

3

$12,131.14$

14

15

17

$20 \quad 0.16$

210.05

220.19

$27,28 \quad 1.46$

$29 \quad 1.12$

$30 \quad 0.01$

31

ILine 3

6

6

8

12

14

17

17

20

21

23

24

Inisy 4

8

$1 \varepsilon$

19

29

Aug 1

0.47

1.65

0.24

0.04

0.01

0.03

0.03

0.14

0.17

0.03

0.04

0.65

0.04

0.57

0.04

0.09

0.03

8

0.02

110.02

$13 \quad 0.01$

$14,15 \quad 1.65$

16

0.01
9.995

8.020

6.325

0
0

12.341

3.187

0.678

22.301

0

0.2345

0.1824

0.1520

0
0

0.2894

0.0766

0.0162

0.5352

0

0

0

34.287

35.850

0.8029

0.8603

0

17.162

38.850

0.4120

0.0324

3. 625

0.0270

0

0

0

2. 217

1. 998

0 0

19.325

6.327

0.1518

0.0292

0.0480

0

0.1640

0

0
0
0

0

0

37.413

0
0
0

0

0

0.8979

0
41.87

34.99

$5 \mathrm{C} . \in \varepsilon$

0

30.15

24.71

8.2.4

46.95

0

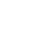

0

0

56.36

76.81

$87.64 \quad 210.040$

56.51

33.680

0.180 0.010,025

36.25 incluaed in 6 th

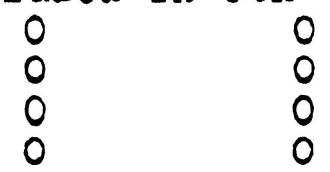

$20.87 \quad 2.024 \quad 0.000,616$

ఒะ.๘ૂ

2. 922

$0.000,889$

Scraxed

$\begin{array}{rrr}0 & 0 & 0 \\ 71.38 & 15.406 & 0.007,733\end{array}$

26.6$$
5.6028
$$

5.6028 
Table 14... Effects of Rainfall upor CuItivated Plot.

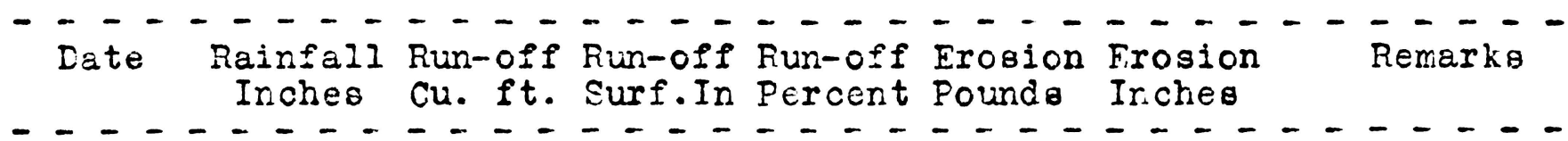

1916

Agr. 15

$$
\begin{array}{ll}
16 & 0.56 \\
17-19 & 0.55 \\
20 & 0.30 \\
21 & 0.04 \\
26 & 0.08
\end{array}
$$

Hay $\begin{array}{rr}26 & 1 \\ 3 & 0.96\end{array}$

$3 \quad 0.31$

$8 \quad 0.20$

$12,131.14$

$14 \quad 0.04$

150.08

17

$20 \quad 0.16$

210.05

$22 \quad 0.18$

$27,281.46$

$29 \quad 1.12$

$30 \quad 0.01$

June $a \quad 0.47$

61.65

6
7 0.24

80.04

90.01

10

11

14

17

20

21

$21 \quad 0.03$

$23 \quad 0.04$

$24 \quad 0.65$

0.03

0.03

0.14

0.17

28

Juily

18

$\begin{array}{ll}4 & 0.04\end{array}$

18

19

0.57

0.04

$29 \quad 0.09$

Aug. $1 \quad 0.03$

80.02

110.02

130.01

$14,151.65$

$16 \quad 0.01$

Total simell.7C

bay 1, ( 108 days) $\begin{array}{rr}9.464 & 0.2272 \\ 6.930 & 0.1663 \\ 6.204 & 0.1489 \\ 0 & 0 \\ 0 & 0\end{array}$

$0.042 \quad 0.0010$

ircluaded in lot

$\begin{array}{rr}0 & 0 \\ 0.372 & 0.0089 \\ 0 & 0 \\ 0 & 0\end{array}$

0

0

2.248

13.750

13.610

24.980

1.835

0

0

0.0540

0.3299

0.3267

C. 5996

0.0439

39
0
0

0

0

0

0
0
0
0

0

0.494

0

0.0031

40.57

30.24

49.63

0

0.11

0.78

0

0

0

0

3.70

29.46

69.51

36.34

18.30

0

0.236

$8.1030 .002,466$

included in i6th

$1.4310 .000,436$

0

0
0

Syaded 6" deep

$\begin{array}{rr}0 & 0 \\ 0.002 & 0.000,001 \\ 0 & 0 \\ 0 & 0\end{array}$

0

0

0

$9.810 \quad 0.002,986$

included in $27,28 \mathrm{th}$

$32.800 \quad 0.009,982$

$2.9600 \quad 0.000,901$

$3.930 \quad 0.001,196$

included in 6 th

0
0
0
0
0
0

0

0

1.82

0

c

0

0
0

0

0

0

0

0

$0 \quad 0$

0

$18.369 \quad 0.4409$

0

Started

Cultivated

Cleaned platform

Cultivated

CuItivated

0

- Mostiy plat-

forn run-off

Cultivated

Cultivated

Cultivated

Cleaned plat- 


\section{PLATE-VIIII}

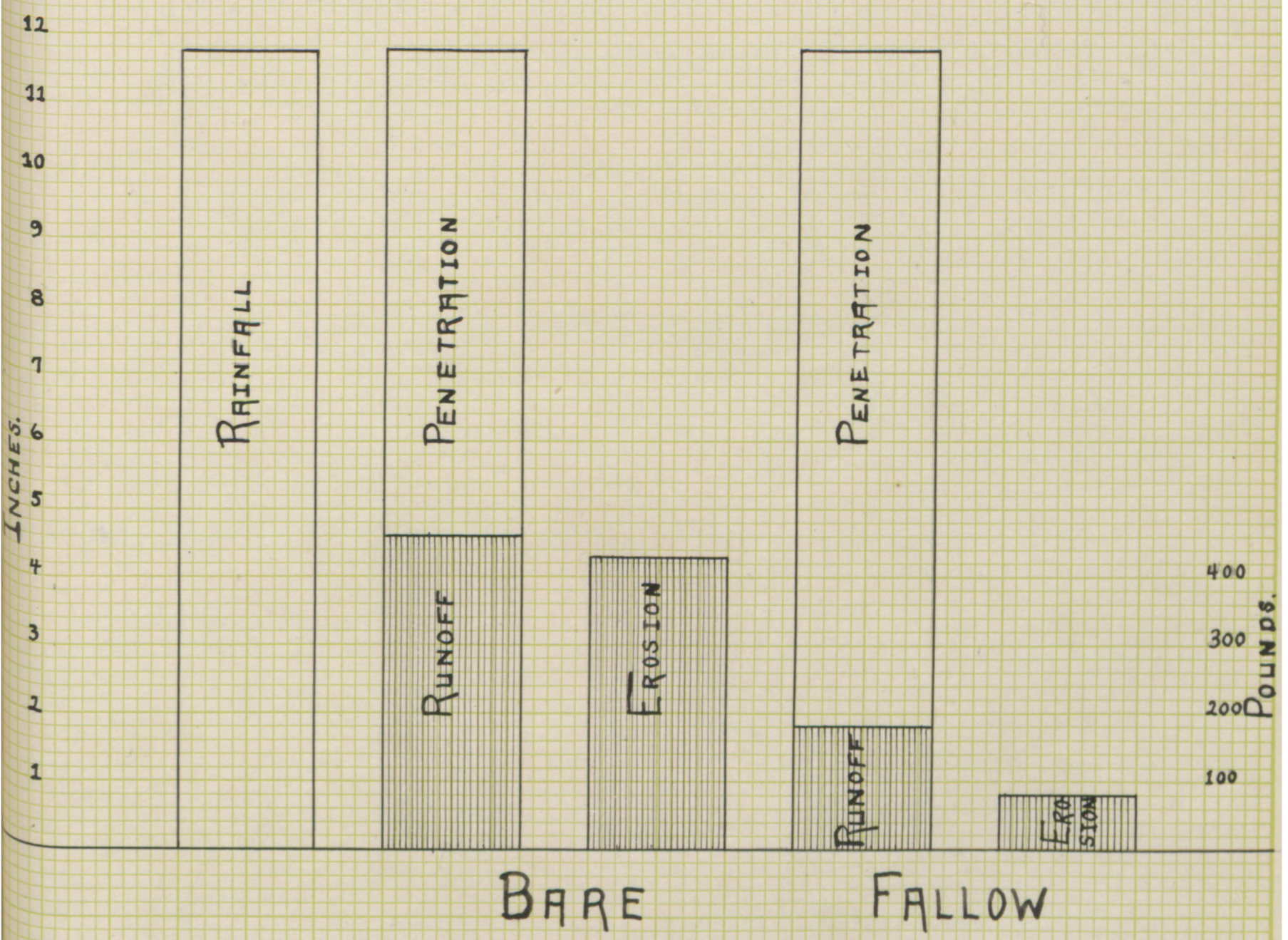

Relationship of Rhinfall

Run-off, Penetration, ${ }^{\text {Tond Enosion on }}$ CULTIVATED FND LNCULTIVATED SoIL. 
Table.15.- Percentage of Woisture in Soil Sam les taken

from Plot A-B.

Top of Hill

1st and 3 sd 4 th 1 st

loot foot foot foot center of Hill

and $3 x d 4$ th
Bottom of Hili

Ist 3nd 3rd 4th foot foot foot foot

$16\{13.23 \quad 14.68 \quad 17.76 \quad 15.33 \times 14.5523 .21 \quad 17.45 \quad 14.98(16.5014 .63 \quad 14.7314 .68$

heg Sampler broken.

* Tead of King Sampler was twisted off.

"Due to indications of rain, sarples were takenof first and second feet from hole at upper end of plots. 
Table 16.- Percentage of loisture in soil samples taken

Top of Hill

Y $-\ldots-\ldots$

te

(1) st 3 ind $3 r d$

$4 t i 28 t$ zinco

Center or. Hili

उrat
Bottom of Hill

3nd 3rd 4 th

foot foot foot

loot foot foot foot foot foot foot foot

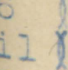

$26\{18.08 \quad 31.46 \quad 19.97 \quad 25.31 \% 18$

15.5136 .9418 .9517 .438

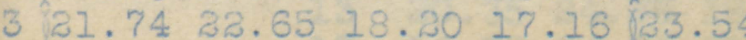

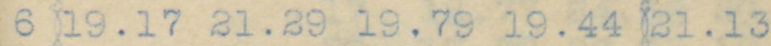

$10 \times 17.77 \quad 23.27 \quad 19.54 \quad 18.78(19.75$

.3424 .53235 .59 $33.62\{19.59$

.0234 .50

.5021 .3518 .93 e

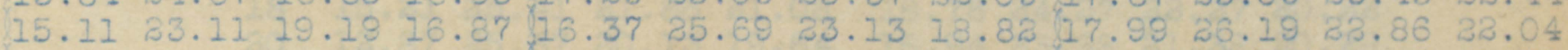
$14.38 \quad 22.4920 .31 \quad 18.18 \quad 16.4624 .4423 .39 \quad 19.41 \quad 16.4826 .35 \quad 34.32 \quad 31.79$

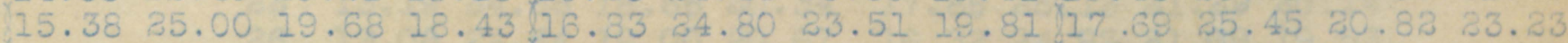

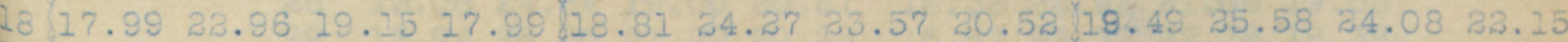
20 $16.02 \quad 33.87 \quad 19.90 \quad 15.86 \quad 16.73 \quad 33.68 \quad 33.96 \quad 33.36 \quad 18.08 \quad 33.30 \quad 20.39 \quad 23.66$ 23 $17.05 \quad 23.90 \quad 17.55 \quad 17.94 \begin{array}{lllllllll}17.74 & 35.10 & 34.39 & 30.36 & 18.85 & 36.39 & 21.04 & 32.32\end{array}$

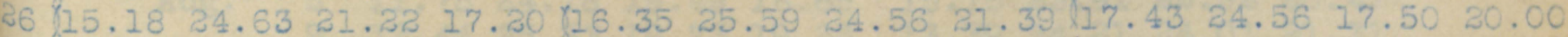

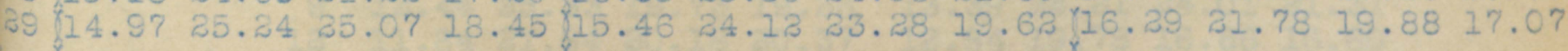

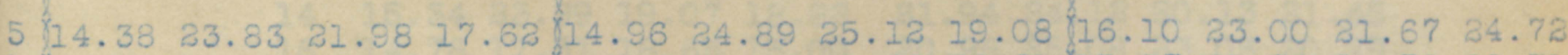

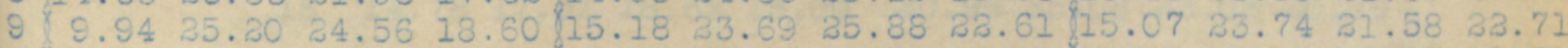

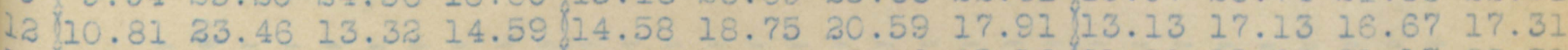

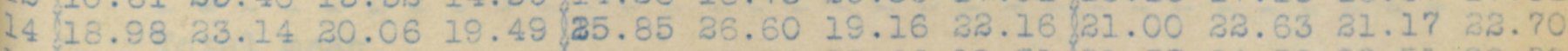

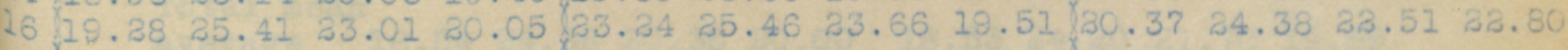

truck rock and could go no further.

king Sampler broken.

Due to indications of rain, samples were taken of first and second 
Table 17. = Average percentage of moisture in soil samples.

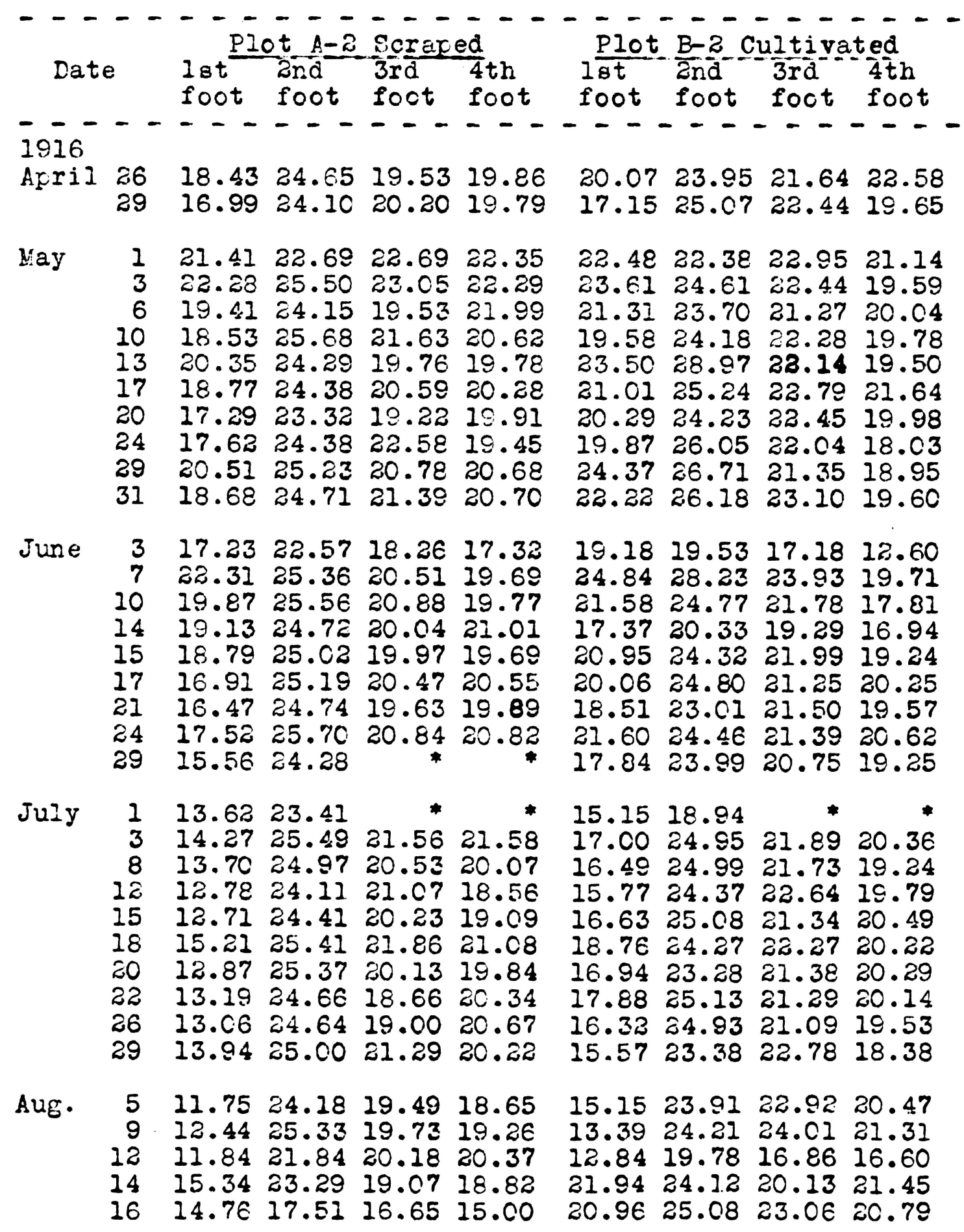

Total mean

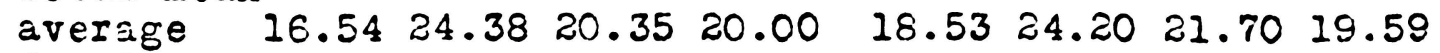
for season

* See footrotes bottom of Tables 15 and 16. 


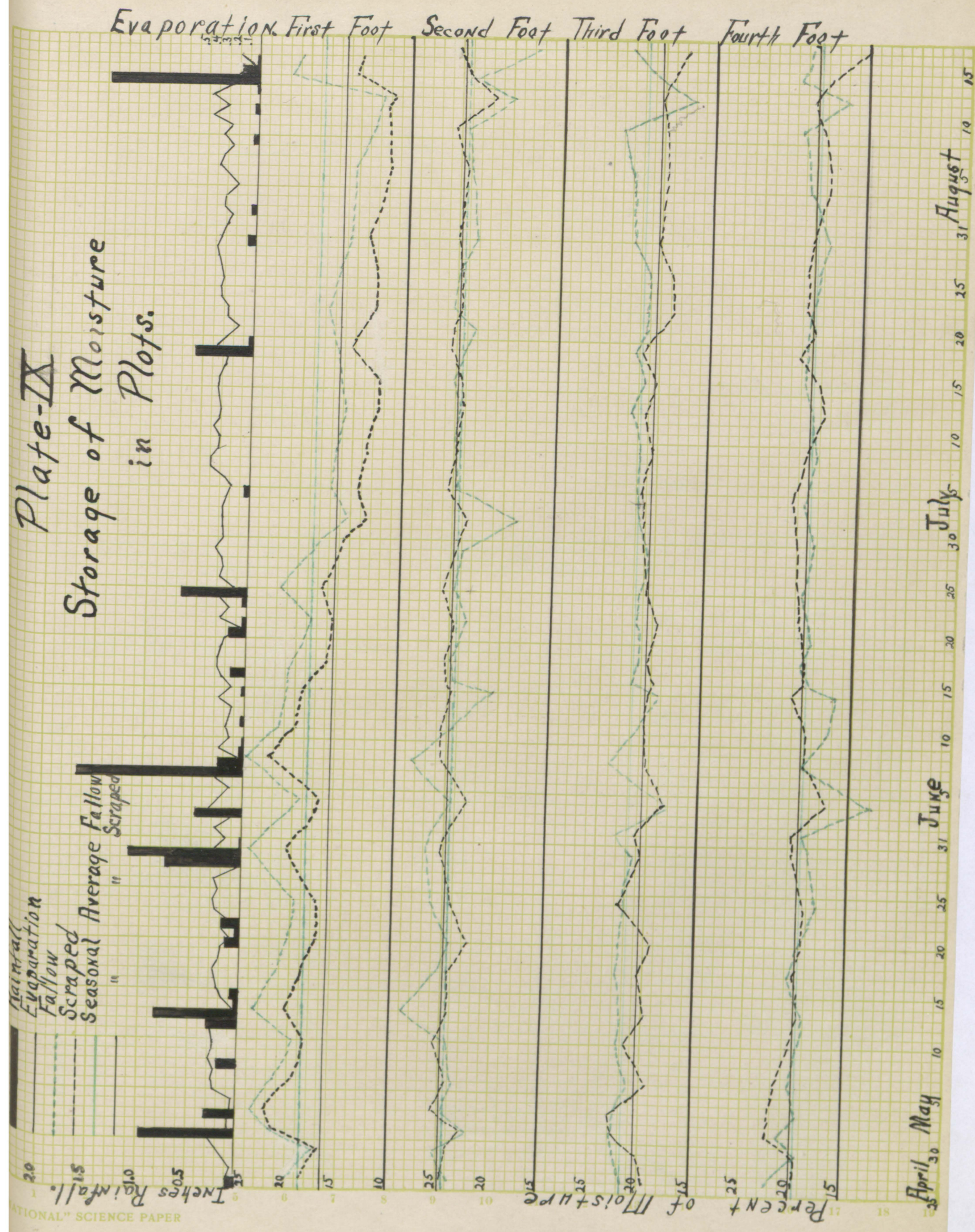


Table 18. - Evaroraticn effects upon plots.

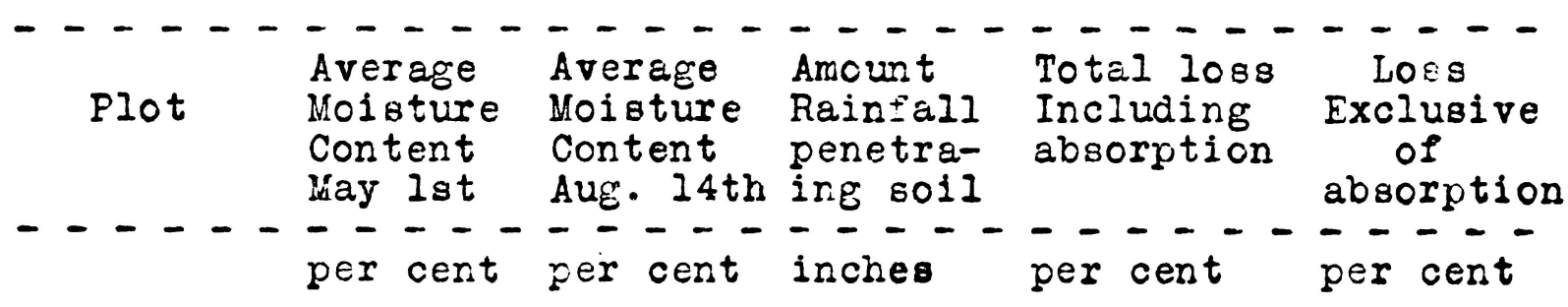

$\begin{array}{llllll}\text { Scraped } & 22.29 & 19.13 & 6.10 & 3.16 & 11.47 \\ \text { Cultivated } & 22.24 & 21.91 & 9.90 & 0.33 & 12.41\end{array}$

* Calcuiated upon basio that no moisture was lost thru percolation.

Table 19. - Moisture conditions in so1 after oix weeks or drying weather = June 25 th to Aurubt 4 th.

Depth of Section Plot A-a Scraped Plot B-a Cultivated

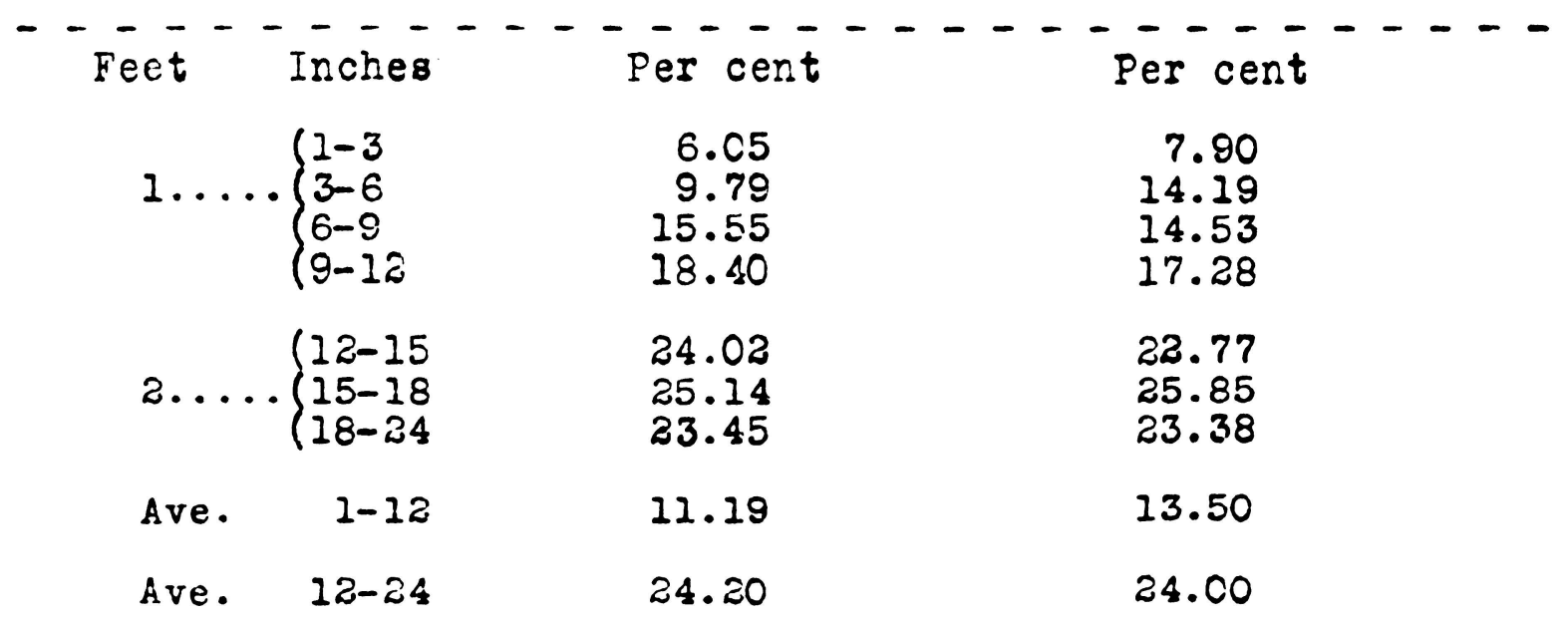


Table 20. - Hoisture conditicns in Lysimeters.

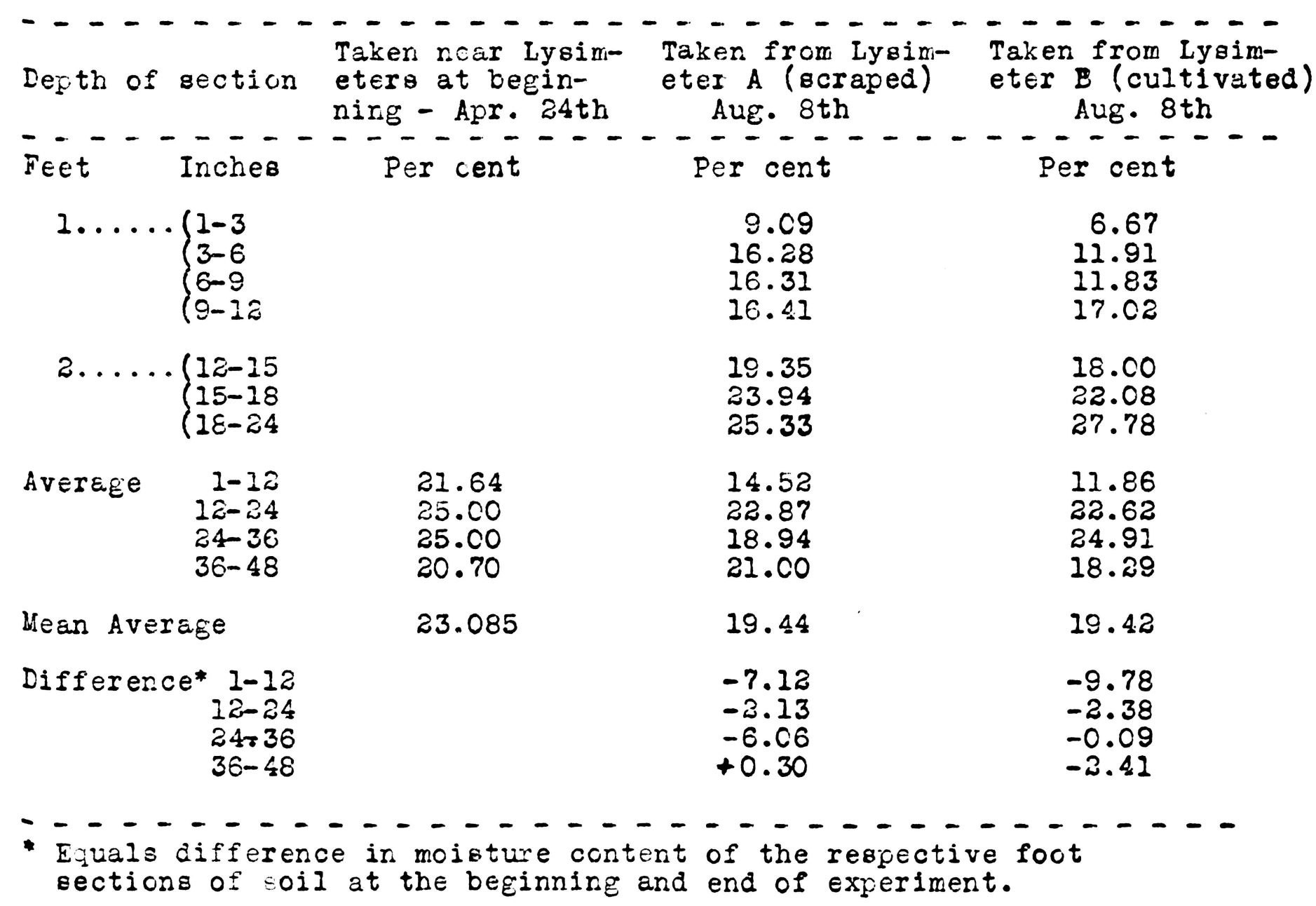

TabIe_21.. = Evaroretion effects upon Lysimeterg.

(Nay 10 th to Aug. 8th, incl.)

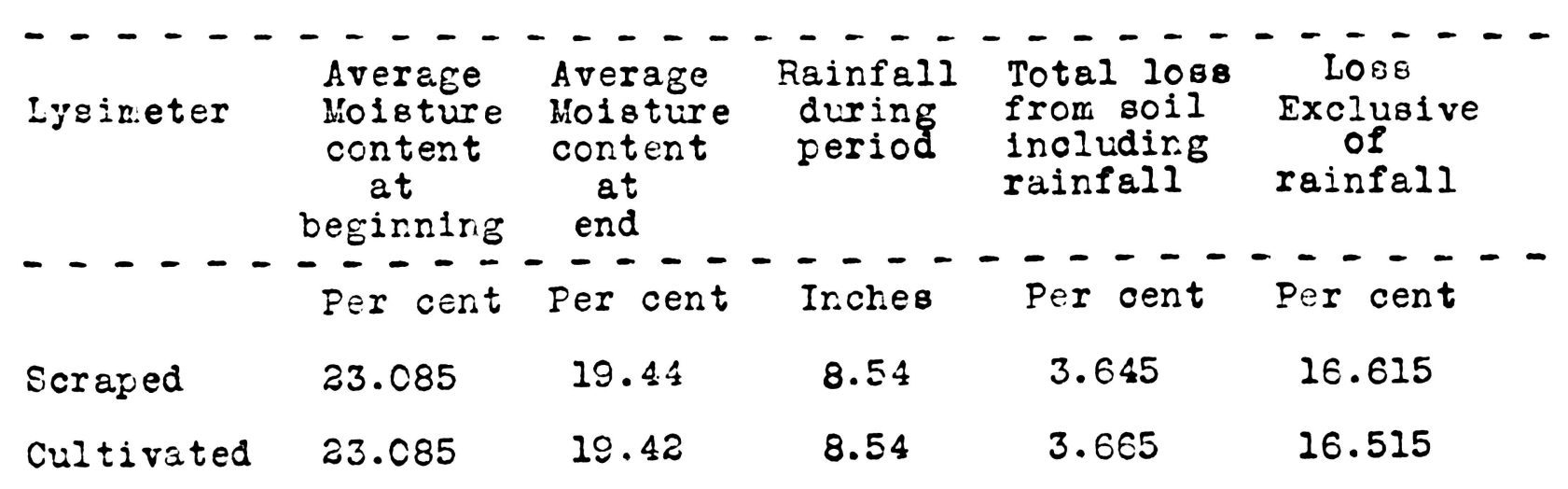


Table 2a- Reoord of Meather Observations.

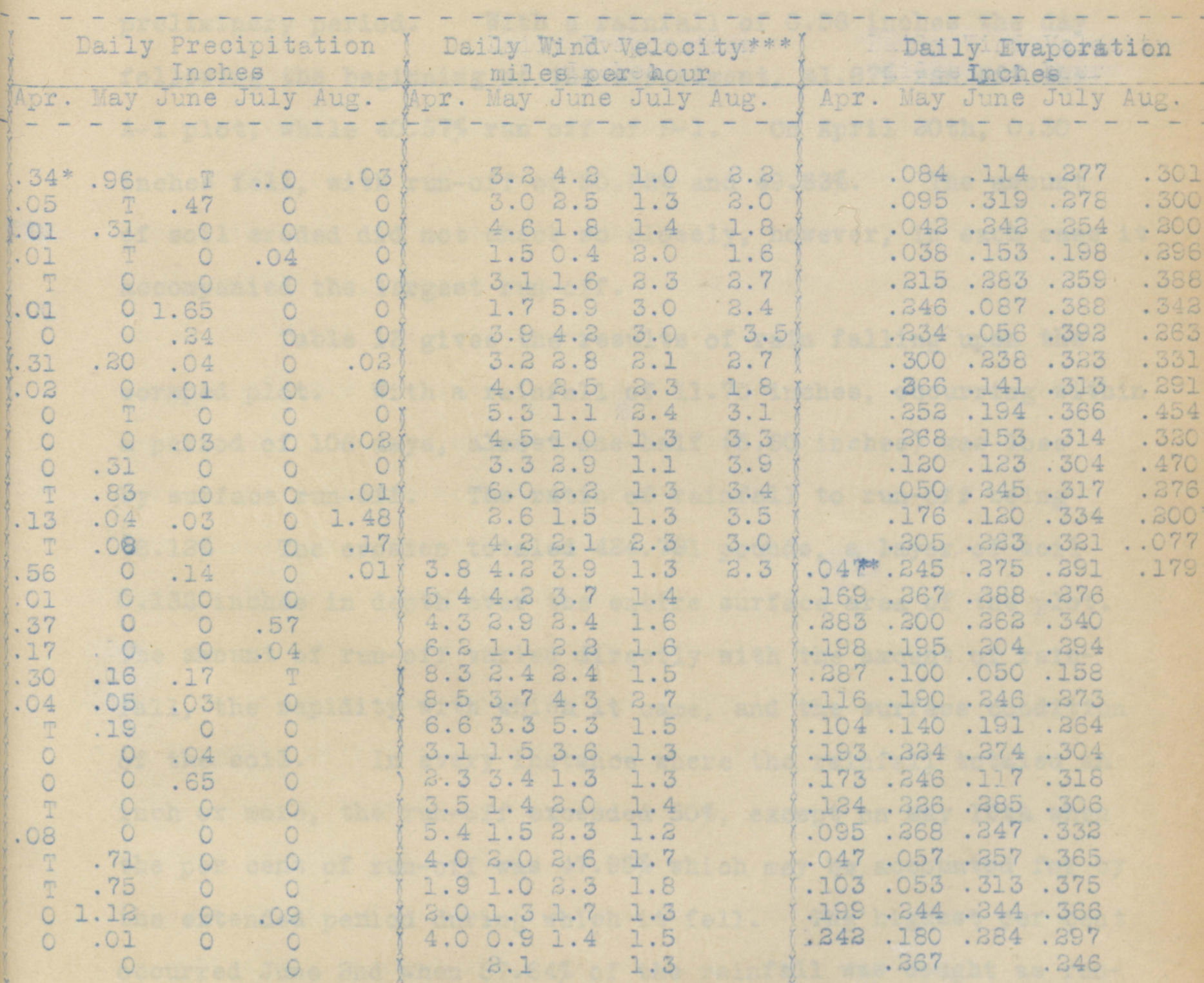

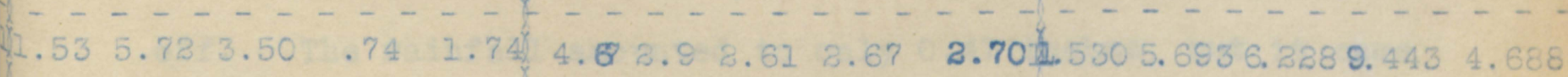

Rainfall April 1 - 14, incl., taken from U.S.W. Bur. Report.

* Estimated.

* Total at bottom represents lean hourly wind velocity for the respeotive moniths. 


\section{General ObservEtions -}

As will be observed from Tables 13 and 14 the plots checked with each other with reasonable closeness during the. prelimirary period. With a rairfall of 0.56 irches the day followirg the beginning of the experiment, $41.87 \%$ ran off the A-1 plot, while $40.57 \%$ ran off of E-1. On April 20th, 0.30 inches fell, with run-off of $50.68 \%$ and $49.63 \%$. The amount of soil eroded did not check so closely, however, in each case it accompanied the largest run-off.

Table 13 gives the results of rain falling upon the ocraped plot. With a rainfall of 11.70 inches, occurring within a period of 108 days, almost one-half (5.60 inches) was 1088 by surface run-off. The ratio of rairfall to run-off being 48.12\% The erosion totaled 424.721 pounds, a layer of soil 0.132 inches in depth ov $r$ the entire surface ara of the plot. The amcunt of run-cff varied directly with the amount of rainfall, the rapidity with which it came, and the surface condition of the soil. In every instance where the rainfall totaled an inch or more, the run-off exceeded 50\%, except on May lath when the per cent of run-off was $47.95 \%$ which may be accourted for by the extended period during which it fell. The highest per cent occurred June and when $87.64 \%$ of the rairfall was caught as runoff. The rainfall amounted to only 0.47 inches, but it came with a dash and fell withir a limit of 36 minutes, from 6:31 a.m. ur.t1l 7:07 a.m. In striking contrast to this, on July 18th with a rainfall of 0.57 inches falling during a period of 2 hours and 17 mirutee, only $26.64 \%$ ran off, and likewise the amount of erosion was a great deal less, about one-twentieth as much. Less than 0.10 inches of rainfall produced no run-off. 
Wuch derended upon the condition of the soil as whether it was wet or dry as to the run-off. On May 8 th and June 7 th the rairfall was 0.20 and 0.24 inches regectively. The run-off from the forner was $8.14 \%$ and the latter $36.25 \%$. Both were preceded by a rainy pericd,but in the case of the latter it was rore extended. On May 20 th and a2nd with rairfalls of 0.16 and 0.19 inches no run-off occurred, the period preceding being dry. There are undoubtedly cases, particularly where the rainfalls in a short time, that a dry soil would absorb less than one which was moist but not saturated at the surface.

Table 14 gives the results of rain falling upon the cultivated clot. A striking difference is noticed in the results as compared with the scraped plot. Only 1.8080 surface inches was caugt as run-off during the period of 108 days. The ratic of rainfall to rur-cff being 15.53\%. The erosion totaled 82.256 pounds or about one-fifth the anount that occurred on the scraped plot. The amount of run-off varied directiy with the ancunt and the raridity of the rainfall, altho, rot so closely as in the case of the scraped plot. The naximun run-off was $69.51 \%$, occurring on June and wher the duraticn of the rainfall was 36 minutes. Fith this exception the run-off never exceded 37\%. The run-off was practlcally nil from rairs less than one inch, eapecially when soil was not compact and wet frcm a previous rain. The erosion varied directly with the runoff. The seaecn being dry, the rainfall was never sufficient to give much run-off on the cultivated plot. It is very protable that had the rainfall at times been very heavy the erosion on the cultivated plot might have greatly ex- 
ceeded that on the scraped plot.

The moisture conditions in the soil on the different days of ampline are shown in Tables 15 and 16. Table 17 gives the average of the firat-foot, second-foot, third-foot, and fourth-foot samples of each plot on the respective days of sampling, as well as the mean average for each foot thruout the period.

As is clearly shom by Plate IX, page 84, the surface foot of the cultivated contained consicerable more moisture than the scraped one, which is proof that the decreased run-off in the case of the cultivated plot was noticeably affecting this layer. The fluctuation of both curves due to rainfall and eveporation are almost lientical. Both vary with small amounts of rainfell. From the beginning until June 15th both were consicerable above the average. Thereafter, there was a gradual decrease due to the continued ary spell until the rain of August 14 th when both increased. The rain of July 18th caused the amount to increase in the surface foot of both plots, but caused little or no effect on the lower layers. The mean seascnal average was $16.54 \%$ for the scraped plot and $18.53 \%$ for the cultivated plot.

The moisture in the second-foot layers of soil did not fluctuate nearly as much as in the surface foot, which goes to show that the rairfall and evaporation changes did not effect it nearly as much as the surface foot. This layer in both plots cortalred by far the most moisture, contalring at times as much as $28 \%$ to $29 \%$, and rarely falling below $20 \%$. The mean average was $24.38 \%$ for the scraped plot and 24.20 for the cliltiváted plot. 
The third-foot layers varied still less than those of tine second. Thruout the season they were nearly constant. On June 3rd the samples for all the feet were low which is unexplainable unless posaibly duto an error in drying. The mean seasonal average was $20.35 \%$ for the scraped plot and $21.70 \%$ for the cultivated plot. The latter being 1.35\% grater. The curves of the fourth feet run nearly in urison varying slightly from the avcrage. The mean average for the scraped plot was $20.00 \%$ and $19.59 \%$ for the cultivated plot. The long dry spell during the summer had no particular effect uoon lowering the moisture content of the tinee lower layers below the seasonal average. The cultivated plot contains the most moisture, and most of that is in the first and third-foot layers.

The total percentase losa from the top four feet for boti plots between May lat and August $14 \mathrm{th}$, inclusive, is show in Table 18. The fact that there is such a great difference in the readings of the scraped plot is due to the fact that the run-off was high on the scraped plot. In the case of tine cultivated plot 3.80 inches more rain penetrated the soil than did in the ocraped plot.

Table 19 show the condition of moisture within the soil after six weeks of very drying weather. In order to obtain a representative saraple from which to make the molature determination, a composite sample of soil taken from three different holes was usel. In the surface three inches there was $1.85 \%$ more moistire in the cultivated plot than in the scraped plot. From thres to aix inches the cultivated plot contained $4.10 \%$ more moisture. From six to nine inches they were about equal, 
there being a slight percentage in favor of the scraped plot. The percentages of moisture in the other deptins were nearly the game. The averae per cent in the surface foot of the scraped plot was $11.19 \%$ and in the cultivated plot $13.50 \%, 2.31 \%$ more moisture in the latter. The second and third feet of both showed they were practically equal.

During this time 0.77 inches of rain fell, all of which occurred in five light showers. The largest was 0.57 inches on July 17tin. The balance came in four showers of $0.04,0.04$, 0.09 , and 0.03 inches respectively. The mean temperature was 81.5 degrees $F .$, the total evaporation from free-water-8urface 12.17 inches, and the mean hourly wind velocity 1.88 miles.

There was no percolation thru the lysimetera during the period of their operation. All the rain which feel entered the soil and was either lost by evaporation or retained in the soil masa. The moisture content of the soll before it was encised, as well as the moisture content near the end of the experiment, is shown in Table 20. Lysimeter $A$ shows a higher percentare of moisture than $B$ in each of the 3-inch samples of the surface foot except the last. The average for the entire foot was $2.65 \%$ in favor of A. Ir the second foot, samples 12-15 and 15-18 inches in A contained more molsture than those of $B$, however, the layer from $18-24$ inches in $B$ contained $3.45 \%$ more moisture than $A$. The average for the entire foot was glightly in favor of A. The third foot of B contained 5.97\% more moisture tinan A. In the fourth foot A contained 2.71\% more moisture than $B$. The averages for the entire columns were practicaily equal, $19.44 \%$ in $A$ and $19.42 \%$ in $B$. In Table al the amount of moisture that has been 108 a due to evap- 
ation is shown. The striking thing is that the loss from both Iysimeters, irrespective of the condition of their surface, is practicaily equal. If anything the cultivated lysimeter lost slightly more moisture than the scraped one. The total 108 s incluaing rainfall was $3.645 \%$ from $A$, and $3.655 \%$ from $B$. The total rainfall for this period, May 10 th to August 8 th inclusive, was 8.54 inches, and the evaporation from the free-vater-surface was 22.255 incher.

Tabel 22 gives the daily precipitation, daily wind velocity, and daily evaporation from a free-water-surface. The total rainfall from May lst to Auguat 16 th inclusive, was 11.70 inches; the mean average wind velocity was 2.71 miles per hour; and the total evaporation was 26.052 inches. The greatest rainfal occurred during the month of May, totaling 5.72 inches, the smallest during July when 0.74 inches fell. The maximum rain, 1.65 inches, fell on June 6th. The longest period without rain was 13 days, from July 5 th to 17 th. From June 25 th to August 14 th only 0.82 inches fell which was one of the longest dry periods ever occurring in this region.

The wind reached its highest mean hourly velocity during April, an averase of 4.67 miles per hour. During May, Jure, July, and August, the average mean houriy velocities were practicilly equal. The maximum mean hourly velocity for one day occurred on April 2lat, the minirum on June 4 th, it being 8.5 miles on the former date and $0.4 \mathrm{miles}$ on the latter.

The largest evaporation occurred during July, the month of least rainfall. 9.443 inches evacorated, over 12 times the amount of rainfall during this month. The lesat occurred during April. Every month the evaporation exceed- 
ed the rainfall except during May when the rainfall was the most by 0.27 inchea.

\section{Discussion of Results -}

The results obtained from the field experiments show several interesting things. The relation of rainfall to runoff is affected very noticesbly by the surface condition of the soil. The condition of the surface is the important factor in controlling run-off and eroaion, thus increasing or decreasing the moisture content of the productive layers of soil and the great waste of the humus layer of soil. The run-off was over three times as great and the erosion five times as much on the scraped plot as uron the cultivated plot. Next to the condition of the surface in controlling the rur-off, is the amount and rapidity of the rain. If large or small amounts come ouddenly, not giving the soil time to absorb it, most of it runs off and is of jittle avail. When it comes slowly, most of it is absorbed. The power of absorption decending directly upon the surface, the more compact the surface, the sooner the water starte running upon the surface and leaves the soil as run-off. This seems and no doubt is a great function of the dust mulch.

The results obtained from the lyaimeters, as well as the moisture conditions of the soil after six weeks of drying weather, would clearly indicate that very little water ia being lost by evaporation thru capillary action. In the case of the lysimetero whers the entire rainfall entered the soil, the evaporation 1088 s were practically equal under both conditiona. 
There was a greater decrease in the moisture content in the layers of the scraped plot than from the cultivated plot, however, which is clearly and conclusively explained by the fact that more rain penetrated the cultivated plot to replenish the loss due to the continued evaporation.

The curves showing the variation of moisture within the different foot layers are proof that the great loss of moisture by evaporition is occurring in the surface foot of both plots irrespectivg of their surface condition. The second foot contained an abundant and conatint supply of moist:r e irreapective of the decreasing supply in the first foot.

It would seem that if capillarity was an important factor in controlling the evaporation 108s, and if the mulch serves as a means of controlling evaporation losaes, that the moisture content of the scraped soil should have been more noticeably affected during the dry period. This was an idoal condition under which to operate, little rain, low humidity, and a high mean temperature.

From the results one must conclude that capillarity plays a very minor part in the evaporation losses of the soil where the water-table is far below the surface; and, that the great importance and gignificance of surface mulch, excepting as it affects weeds, is not that the evaporation is controlled thru the breaking of capillary tubes, tut that it flaces the surface in a consition such that it may absorb rain most readily. Surface mulching and cultivation, other than killing weeda, should be given with the aim of keeping the surface in as ideal condition as possible for absorbing 
the rain that falls. By so doing the moisture content of the soil is not only repleniahed and increased, but the great 1033 due to erosion is impeded in a large way. 


\section{SURMARY AIND CONCLUSIONS.}

Capillary studies were carried on under laboratory conditions with 2-foot, 4-foot, and 6-foot cylinders of soil in duplicates with their bases in standing water. There was a congtant and perfect movement of water thru the 2-foot cylinders, the evaporation 1083 being practically equal to the water-table los:. The movement thru the 4-foot cylinders was not regular, and the evaporation los was considerably more than the water-table 1083. The lo3s from the 6-foot cylinders was in great excess of the amount that moved up into the cyinder from the water-table. The results clearly showed that the dezth of water-table was a deciding factor upon the rate and amount of water lost by capillarity, the loss tinu capillarity decreasing with depth of water-table and being almost negligible at 6 feet.

The study of gravity as a factor in preventing soil moisture from returning to the surface after it has passed thru the surface foot of soil was carried out by taking two 6-foct cylinders of soil and allowing one to lose moisture in an erect position while the otier was inverted. By taking samples at regular intervals thruout the length of the cylinders, the effects of gravity were determined. The 1089 from the erect cylinder Was greatest at the ourface and gradually increased until the least $w a 8$ lost in the bottom layer. The losa from the inverted cylinjer was more or less constant thruout its entire length. There seems to be little doubt that gravity is playing $a$ far more importint part in removing soil moisture and in 
controlling its movements than has commonly been believed. From two enclosed plots, one scrazed and one cultivated, 500 square feet in area, and situated on a hill with an inclination of approximately $41 / 2$ degreea, $48.12 \%$ of a total rainfall of 11.70 inches tas caught as run-off from the former, and $15.53 \%$ from the latter. The eroaion regulting was 424.73 pounds in the case of tine scraped plot and 82.36 pound from the cuitivated plot.

The evaporation losses of the plots as influenced by the condition of the surface seem to be negligible. The far more important function of the mulch seems to be in the control cI the run-off and erosion. Thru the use of the mulch the surface is bect in a better condition for absorbing water. The woisture content of the layers of soil below the second foot were nearly constint thruout the sampling studies, which indicates that very little loss is occurring from them tiru capillarity and evaporation.

It aeems almost conclusively demonstrated that the moisture is lost from the soil under average conditions with a water-table several feet below the surface, not thru the aid of capiliarity, but in a gaseous state as water vapor, this I089 being greatest from the surface foot and decreising rapidIy downara.

If the above conclusions are correct, the value of a wulch in regions where the water-table is deep has been over emphasized so far as preventing the eveporation of moisture is concerned. Further, the cultural methods that have been used supposedly to decrease the capillary rise of moisture, probably assist mainly in ceuring a greater water absorption. 


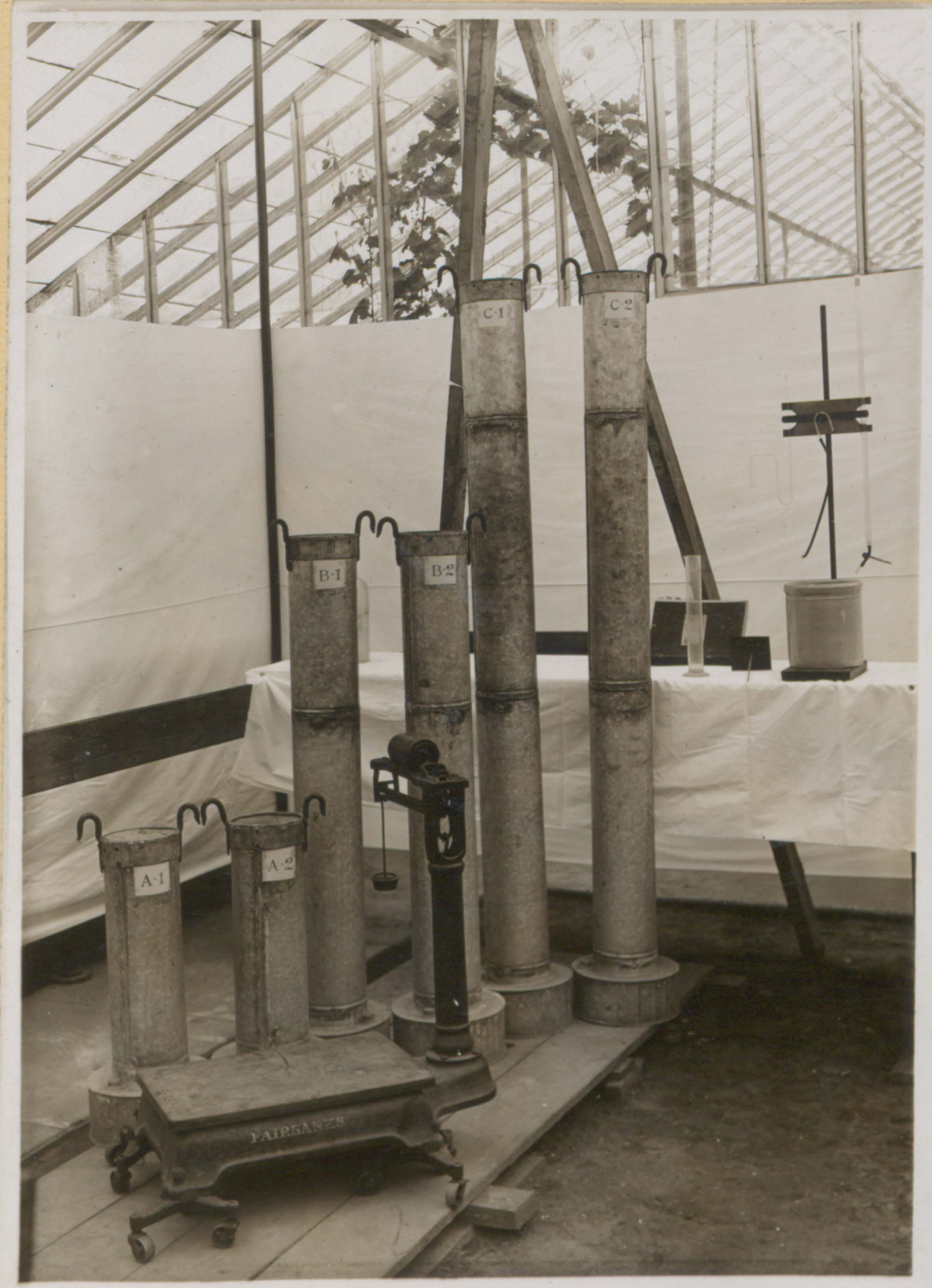

No. 1. - Soll Cylinders used in

Experiment I on platform in greenhouse. 


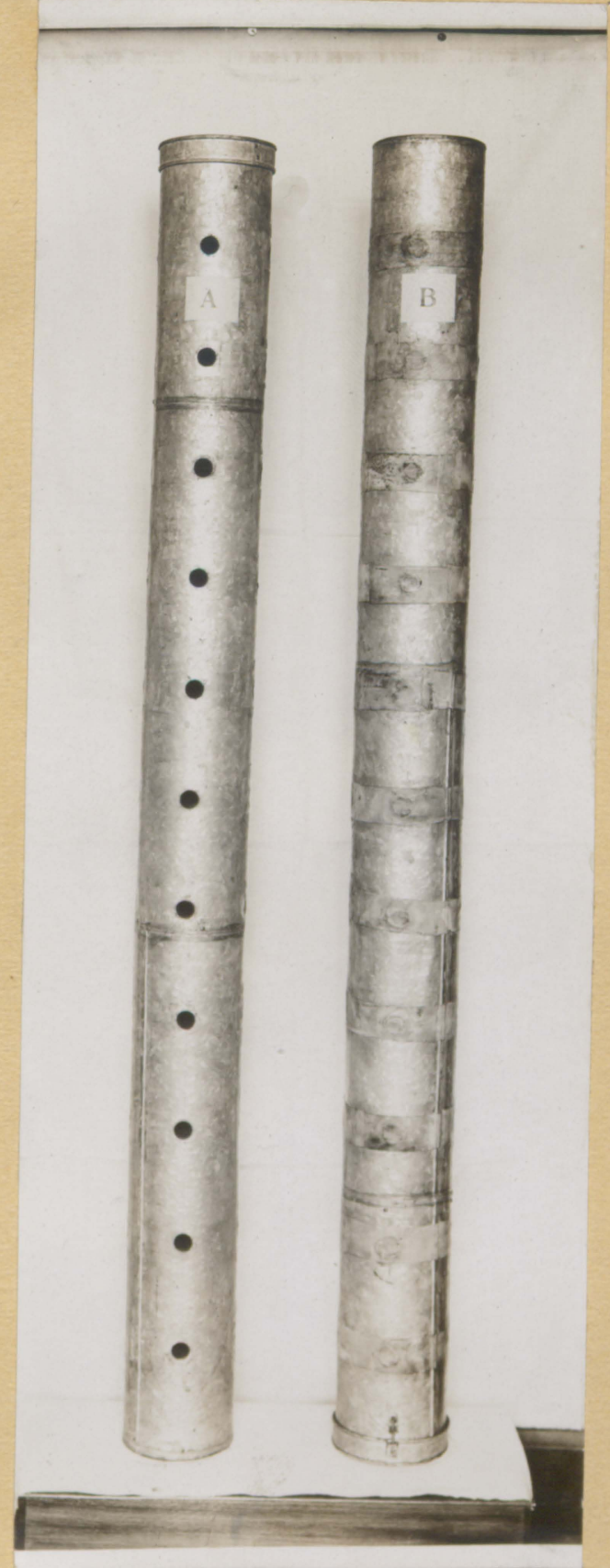

No. 2. - Soil cylinders ured in Experiment II. 


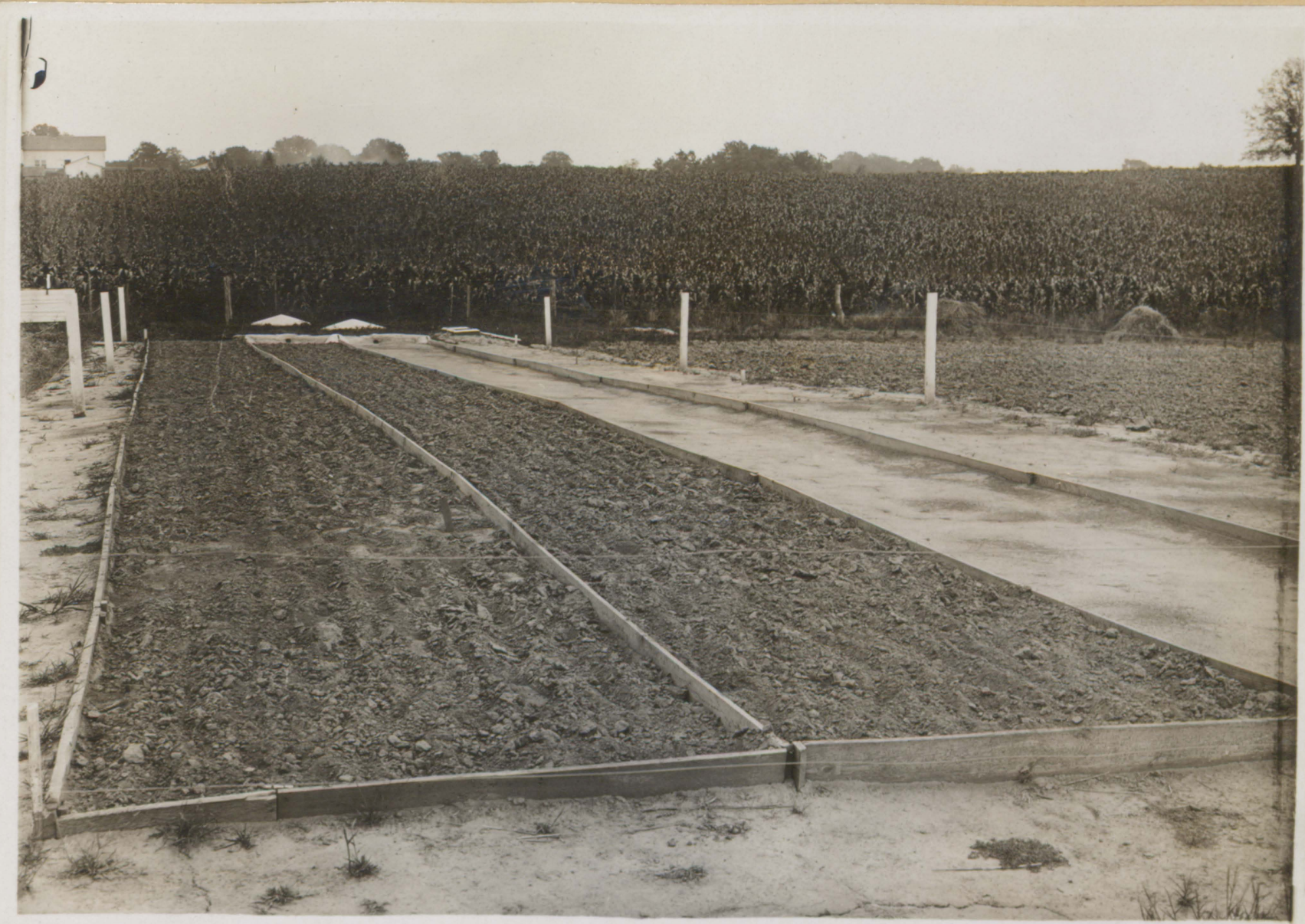

No. 4. - Looking east across field plots.

Weather apparatus in fore ground.

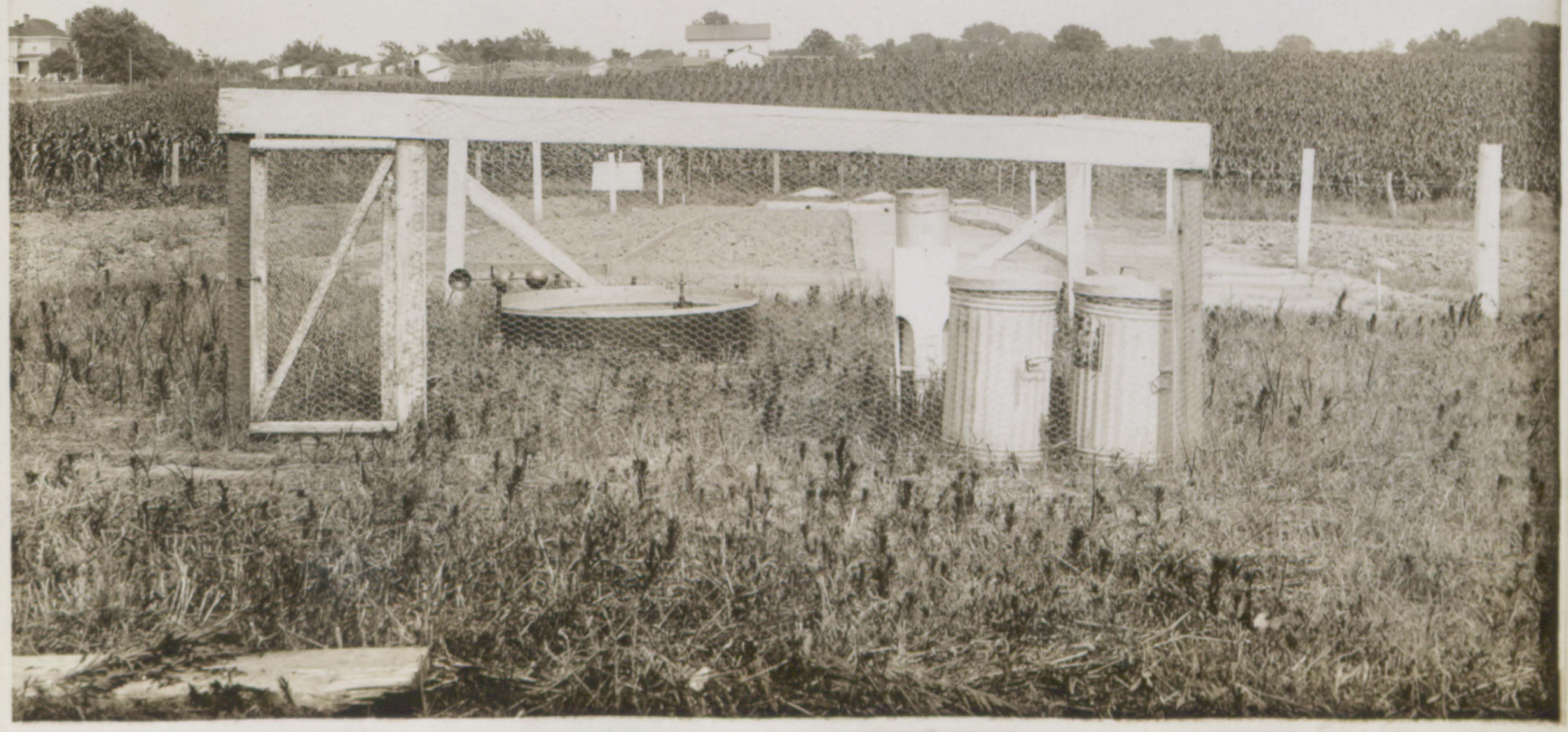




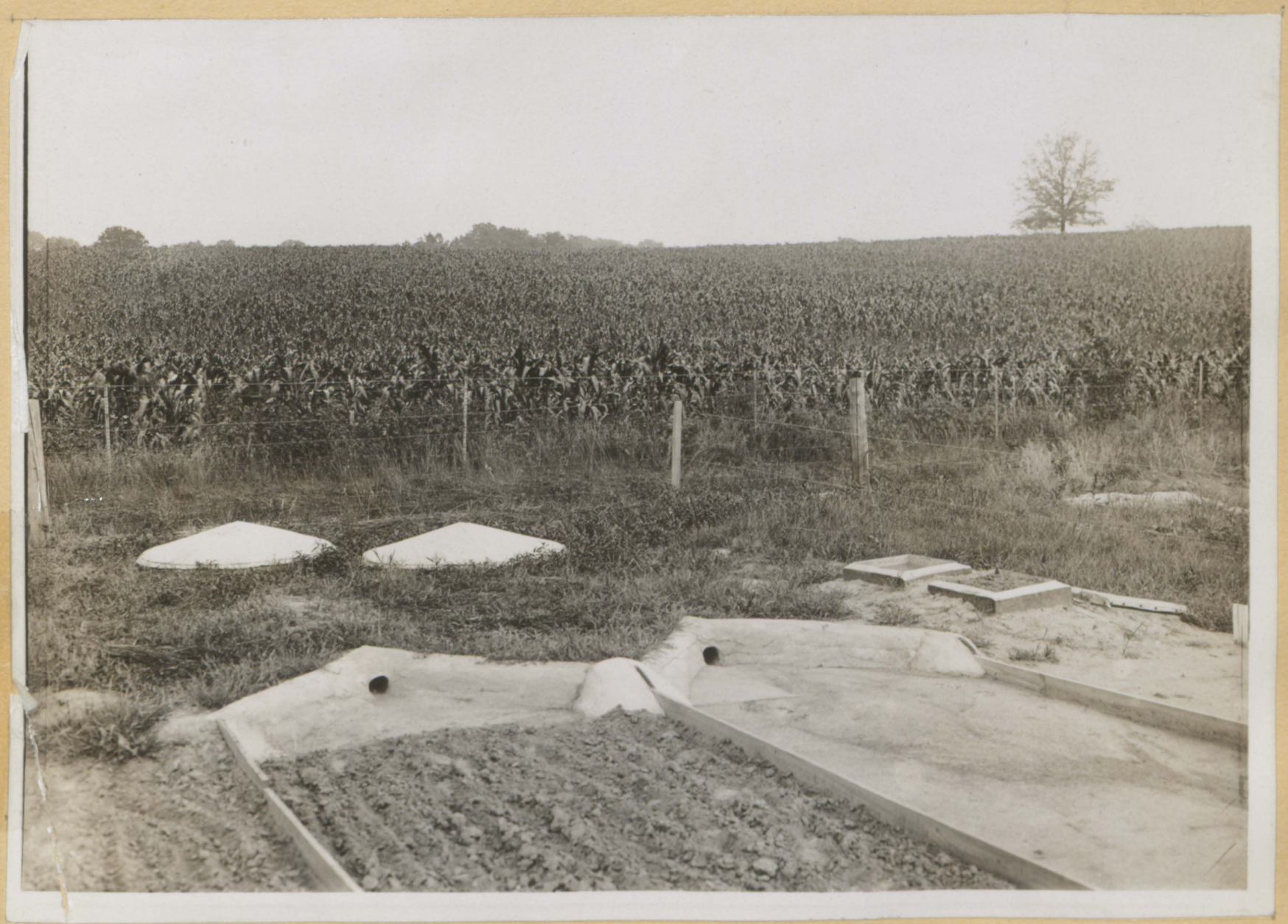

No. 5. - Lower end of field plots, showing catching apparatus for run-off, and lysimeters. 


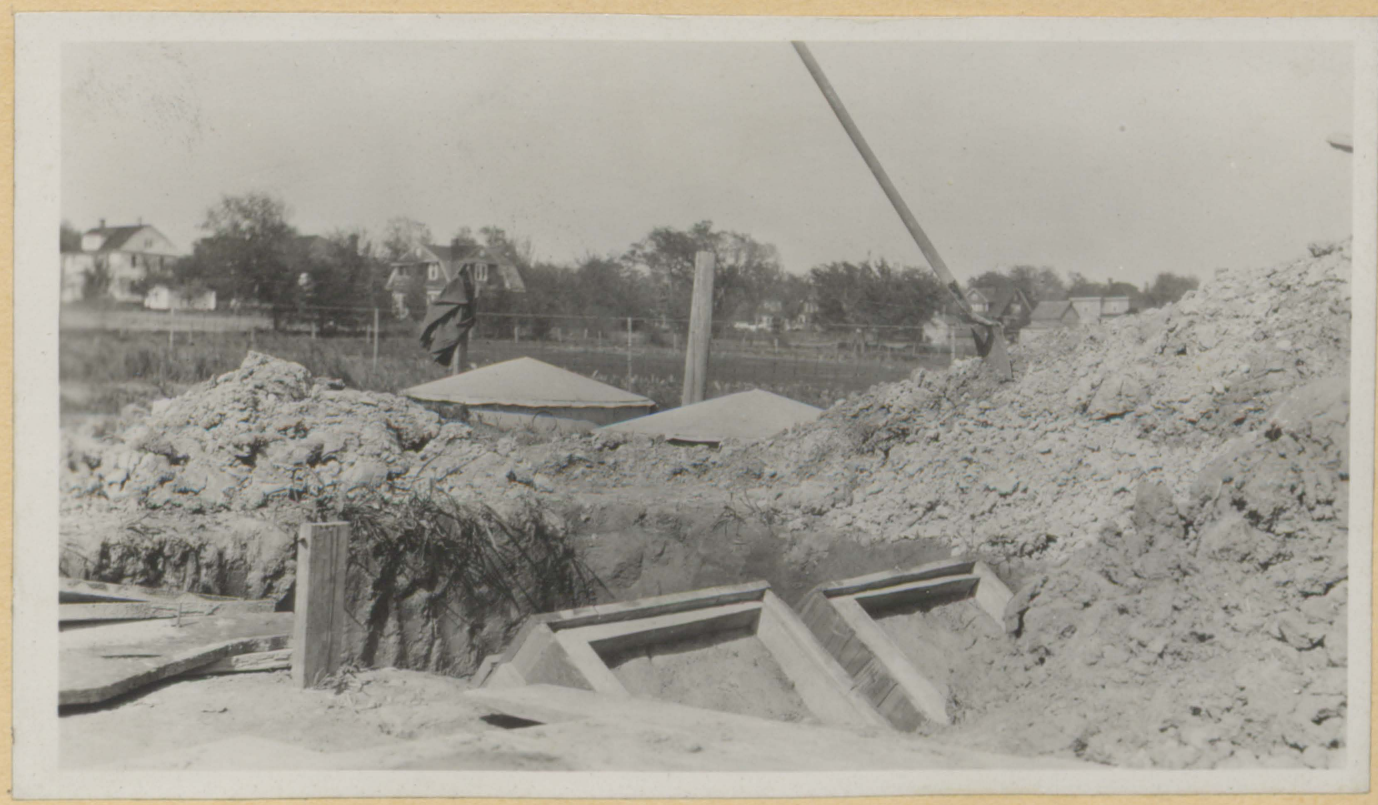

No. 6. - Position of lysimeters when bottoms were installed.

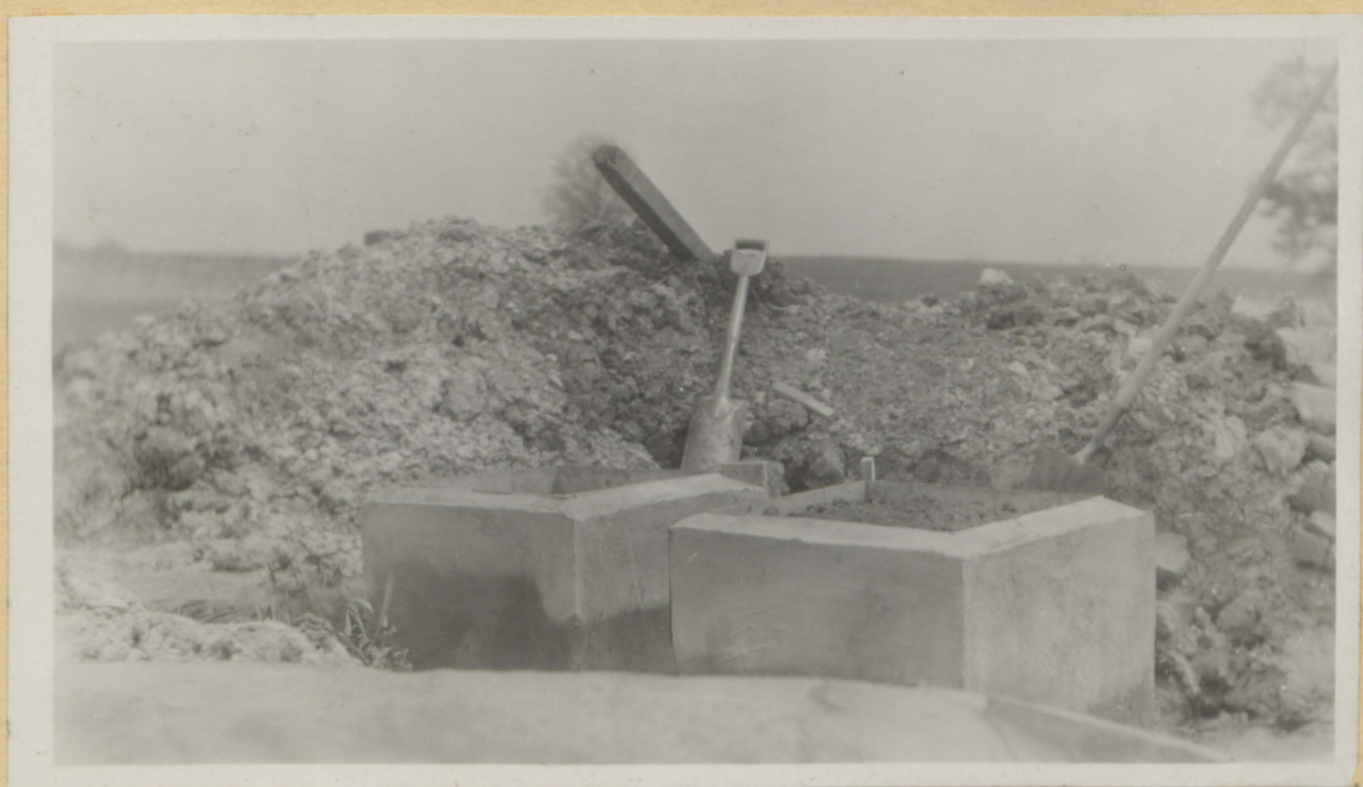

No. 7 - Lysimeters on foundation before replacing soll. 


\section{BIBLIOGRAPHY.}

1. Minutes of Proceedings of the Inetitution of Civid Enginetrs, Vol. XIV, Fart iii. Session 1875-76.

2. Lawes, J.F., Gilbert, J.F., and Farrington, R. On the arount and evacoration of the Rain and Irairage-waters collected at Fothansted. Jour. Roy. Agri. Soc., Series 2, VOI. XVII. 1881 .

3. Ciibert, J.E. On Fainfall; evaporation and percolation. Clowes, Iondior. 1896.

4. Mijier, H.H.T. The amount and composition of the drainage thri unmarured and uncropyed land, Barnfield, Rothamated. Rothanetea Vericire, Vol. VIII. 1902-1912.

5. Hall, A.D. The Sook of the Rothamsted Experinents. London. 1905.

6. Leatrer, J.H. Loss of Water from Soll durine Iry Neather. Nemoirs of Deft. Agri. of India, Chem. Series, Vol. I, pp.79-116. 1908 .

7. Leatrer, J... Records of Drainate in Inoia. Menoira of Dept., Agri. cf India, Chen. Series, Vol. II, pp. 63140. 1911 .

8. Leather, J.W. Evaporation from a plain water surface. Lemeirs Lept. Agri. of India, Chem. Series, Vol. III, pf. 1-15. 1913.

9. Toliny, E. Untereuchungen Uber den Einfluss der Nachtigkett des Eodens auf die Feuchtigkeitsverhaltnisge. Bied. Centr., $23,146.1894$.

10. Lyon, T.L. Tanks for Soil Invetigationo at Correll Univer- 
sity. Science N. Series, Vol. XXIX, No. 746, pp. 621-6a3. 1909. 11. Loughridge, R.F. Invegtigations in Soil Fhysics. California Agri. Exp. Sta., Rept. of work of the Agri. Exp. Stations of Californiz. 1892-4.

12. King, F.F. Soil Fhysics Studies: I - Soil Vater. Wisconsin Agri. Exp. Sta., Sixth Anrlial Rext., fp. 185-206. 1889.

13. King, F.F. Physice of Agriculture. Published by the author, Kadiscn, Misconsin. 1910.

14. King, F.H. Fluctuations in the Level and Rate of licverent of Ground Water. U.S.D.A., Weather Bur., Eul.5, pp. 59-61. 1892.

15. King, F.H. Principles and Conditions of the Moverents of Ground Vater. U.S. Geol. Sur., 19th Ann. Rert., Part 11, 1897-1888.

16. King, F.H. Investigaticns in soil Nanagement. U.S.D.A., Bur. Soils, Bul. 26, Part iii, pp. 125-205. 1905.

17. BriEgs, L.J. The Niechanics of Soll Noirture. U.S.D.A., Bur. Soils, Bul. 10, 1897.

18. Brieges, L.T., and Larham, H.H. The carizlary Noverient of Water in Dry and Noist Soile. U.S.I.A., Bur. Solls, Bul. 19, $\mathrm{pp} \cdot 19-30.1902$.

19. Friछgs, L.J., and VicLare, J.W. The Moisture Equivalents of Solls. U.E.D.A., Bur. Soils, Bul. 45. $190 \%$.

co. Eriggs, L.J. and Shantz, H.I. The Wilting Coefficient for Lifferent Flants and its indirect Determinaticn. U.S.D.A., Bur. Plant Iroustry, Bul. 230. 1912.

21. Wollny, F. Untersuchungen uber die Kapillare Leitung des Wassers im Boden. Forsch. a.d. Gebiete D. Agri.-Physik, Eand 7. Seite 269-308. 1884.

22. Euckingham, F. Studies on the kovent of Soll Moisture. 
U.S.D.A., Bur. So118, Bul. 38. 1907.

23. Iynde, C.J., and Dupre, H.A. On a New Method of lieasuring

the Capiilary lift in Soile. Jour. Arer. Soc. Agron., Va.

V, No. 2, Fp. 107-116. 1913.

24. Widstoe, J.A., and NeLaughin, T.T. The Noverent of Water

in Irrigated Soils. Utah Agri. Exì. Sta., Bul. 115, pp.

223-231. 1913.

25. Alway, F.J. and Clark, V.L. A study of the Nioventent of

Water in an uniform Soil under artificial conditions.

Nek. Agri. Exy, Sta., Twentj-fifth Ann. Rept., pp. 246-ž87. 1913.

26. Alway, F.J. Studies on the fielation of the Non-avaiable

Water of the Soil to the Hygroscopic Coefficient. Neb. Agr. Exp. Sta., Reaearch Bu. 3. 1913.

27. Rotnistrov, V.G. Circulation of Fater. Odessa, I. Skaleky, 1907.

28. Rotnilstrov, V.G. Nature of Drought. Odessa, I.Skalsky. 1913.

29. Burr. T.V.. The Storage and Use of Soll Moisture. Neb.

Agri. Exp. Sta., Research Bul. 5. 1914.

30. Norton, W. H. Elements of Geology. Ginn, Boston. 1905.

31. Hilgard, E.H. Soils. Nactillen, New York. 1911.

32. Toumey, James $\pi$. The relation of Forests to stream flow. U.S.D.A., Yearbook, fp. 279-288. 1903.

33. Rodhouse, T.T. A preliminary Study relating to the Water

Resources of Missouri. Missouri Engineerirg Exp. Sta.

Series Xv., V01. XV, No. 33. 1914.

34. Iyon, T.L., Fippin, F.O., and Buckran, H.O. Soils, their properties and managenent. Mackillan, New York. 1015. 


\section{UNIVERSITY OF MISSOURI \\ ColUMBiA}

COLLEGE OF AGRICULTURE

Dean alter lililer

Academic Hall

Dear Sir:

The thesis of lir. Vifquain is not particularly well or anized. He has included no rezular bibliograpny. A note from him says that this was delayed. The material he has presented is good enough, in my opinion, and I think the thesis is passable. I will therefore approve it.

Yours very truly,

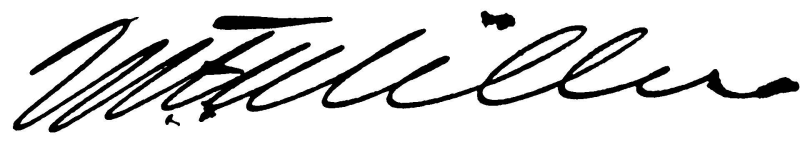

Professor of Soils

I. F. Iiller:NB 


\section{$378.7 \mathrm{M7}$ XV679}

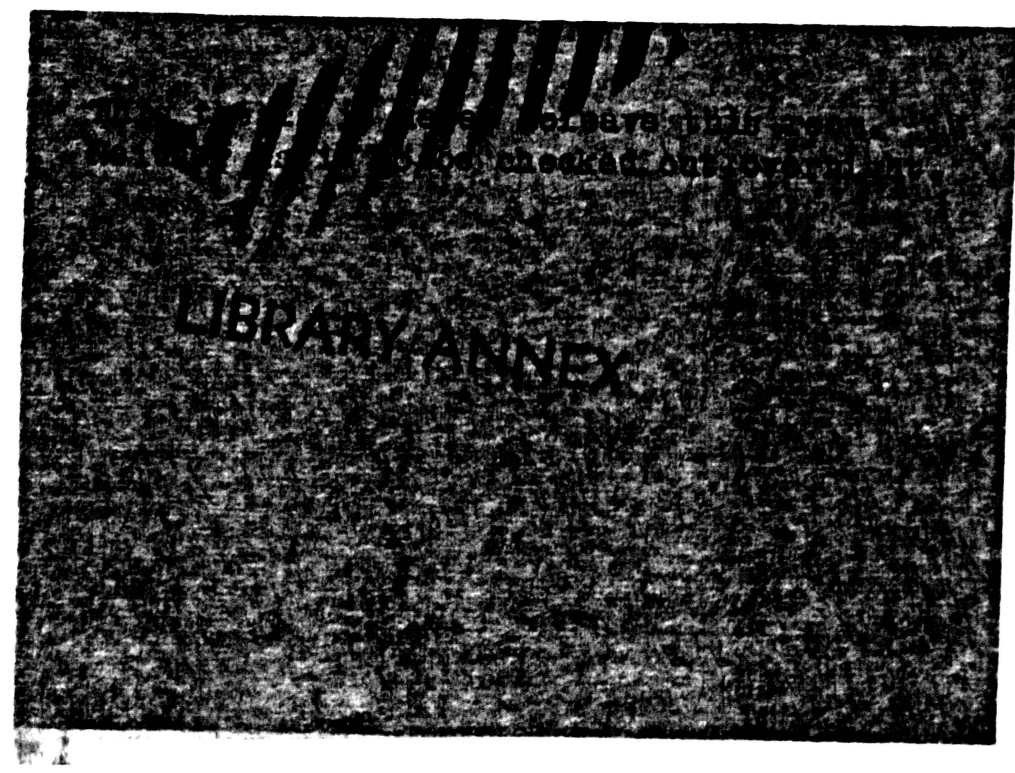


MU Li braries

Vif quain1917specsheet, txt

University of Mi ssouri-.-Col umbia

MU Theses and Dissertations (Pre-1920)

Local identifier

Capture information

Date captured

Scanner manufacturer

Scanner model

Scanning system software

Optical resolution

Color settings

File types

Source information

For mat

Content type

Source I D

Notes
Vi fquain 1917

20160208

Zeutschel

OS 15000

Omniscan V.12.8 SR2 (2675)

$600 \mathrm{dpi}$

grayscale, 8 bit and color, 24 bit

B o ok

Text [with i mages]

$010-100906307$

Some page curvature and data lost at margins

due to tight binding.

Pages typed and single-sided.

Title page has signature and perforated

property stamp.

Text is in blue ink.

Text is very light on some pages.

Some pages have handwritten marginali a

and corrections.

Photographs are pasted in.

Pages 102-106 are inserted out of order and

follow page 98.

An article accompanying this thesis is included.

Derivatives - Access copy

Compression

Edit ing sof tware

Resolution

Color

File types

Notes

Tiff compressed with LZW before conversion to pdf Adobe Photoshop CS5

$600 \mathrm{dpi}$

Grayscale and color

$p d f$

Grayscale pages cropped, canvassed,

and i mages brightened.

Color pages cropped.

Bl ank pages removed.

Pages with very light text were scanned in color to aid in legibility. 